\title{
SOCIAL AND CULTURAL IMPERATIVES OF THE MODERN SOCIETY DEVELOPMENT
}

Collective monograph

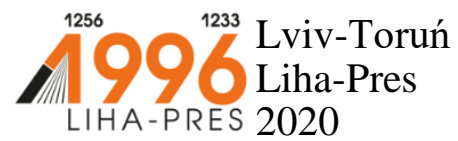




\section{Reviewers:}

Prof. nadzw., dr hab. Stanistaw Kunikowski, Rektor of Cuiavian University in Wloclawek (Republic of Poland);

Prof. $\quad d r$ hab. Kazimierz Pierzchala, Katolicki Uniwersytet Lubelski/Catholic University of Lublin (Republic of Poland);

Prof. dr hab. Stanistaw Juszczyk, Uniwersytet Ślaski / University of Silesia (Republic of Poland).

Social and cultural imperatives of the modern society development : collective monograph / M. Poplavskyi, K. Kyrylenko, V. Pylypiv, etc. - Lviv-Toruń : Liha-Pres, 2020. - 132 p.

ISBN 978-966-397-204-6

Liha-Pres is an international publishing house which belongs to the category "C" according to the classification of Research School for Socio-Economic and Natural Sciences of the Environment (SENSE) [isn: 3943, 1705, 1704, 1703, 1702, 1701; prefixMetCode: 978966397]. Official website www.sense.nl. 


\section{CONTENTS}

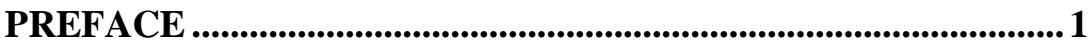

PART 1

CULTURAL PROCESSES IN SOCIETY

2

DOMESTIC EDUCATION GLOCALIZATION

IN THE CULTURE AND ARTS INDUSTRY

IN THE CONTEXT OF WORLD SOCIO-CULTURAL

TRENDS OF THE XXI CENTURY

Mykhailo Poplavskyi .................................................................................2

INNOVATION CULTURE AS A CHARACTERISTIC

OF PERSONALITY AND FORM OF MODERN CULTURE, ITS ESSENTIAL FEATURES

Kateryna Kyrylenko

IDENTITY AND SYMBOLS IN THE CULTURAL SPACE OF THE HUMAN BEING

Volodymyr Pylypiv

.32

INFORMATION AND COMMUNICATION TECHNOLOGIES AS A TOOL OF SOCIO-CULTURAL TRANSFORMATION

Yuliia Trach

PART 2

POLYASPECTIVITY OF THE ART PHENOMENA 63

THEORETICAL CONCEPTS IN THE PRACTICE OF THE SOVIET UKRAINE BALLET CRITICISM IN LATE 1920S

Alina Pidlypska .63 
THE UKRAINIAN DANCE ON THE STAGE AND

IN THE HOUSEHOLD CULTURE OF THE NATION:

CURRENT ISSUES

Olha Boiko

MODERN MUSICOLOGY RESEARCH:

GAME THEORY PROJECTIONS

Kateryna Fadyeyeva

POLY SYSTEM ANALYSIS OF VISUAL COMMUNICATION IN FASHION

Olga Shandrenko 112 


\section{PREFACE}

The modern globalized world makes the problems of preserving the achievements and functioning of culture be the most acute ones. Today, there are positive processes of developing the conditions and environment for the society's formation with the culture playing the dominant role. Increasingly, global politics relies on such concepts as "dialogue of cultures", "tolerance", "cultural diversity", and "world's culture". There have been actualized the studies concerning the issues of new types and kinds of culture, the problem of common human values, and the preservation of the world's cultural heritage as a basis for the existence of humanity in the future.

Today, culture is becoming a defining element for many spheres of social development, a systematic basis for the intellectual integration of a modern discordant man. Culture preserves the social and historical memory, a person's individuality, while drawing him/her to the world values. However, despite the obvious importance of culture as an integral part of society and the only possible way of human existence, it is in the state of crisis today. One of the reasons for this situation is a change in lifestyle as well as in the social and cultural paradigm of the human behaviour. This determines the need to identify new trends in the modern society culture's development, to analyse the peculiar social and cultural picture of the emerging world, and others. Time poses the challenge for the humanities, including theories and history of culture, to find new approaches to studying its internal sources of development, the peculiarities of the culture-forming processes within society, the polyaspectivity of the art phenomena's nature, and the comprehensive study of the contemporary social and cultural situation as a whole. Unfortunately, knowledge of the culture is still rather theoretical and descriptive than practical. But the social sense is at the stage of rationalizing knowledge about culture and society, which makes it possible to realize the significant role of the social and cultural factors in the social transformation process, to influence the social and cultural dynamics processes, to carry out their targeted regulation.

The collective monograph offered to the reader is an attempt to present culture as a major factor of the individual's development and self-realization, the society's humanization, and the preservation of the people's national identity, as an important indicator of the society's quality and at the same time being the measurement of the human's spiritual and value development. 
DOI https://doi.org/10.36059/978-966-397-204-6/2-14

\section{DOMESTIC EDUCATION GLOCALIZATION IN THE CULTURE AND ARTS INDUSTRY IN THE CONTEXT OF WORLD SOCIO-CULTURAL TRENDS OF THE XXI CENTURY}

\section{Mykhailo Poplavskyi}

\section{INTRODUCTION}

Traditional culture of the Ukrainian people in particular, as well as the cultural diversity of human civilization in general, at the present stage is influenced by a complex process, leading trend which is to promote models of Western mass culture. This is a consequence of globalization processes, which, according to researchers, give rise to uniform structures in the economy and politics of different countries, as well as contribute to the adaptation of modern Western culture elements to local conditions and local traditions and it is the so-called "globalization". These processes, which over the last decades have embraced all branches of social life (political, economic, spiritual, social, etc.), have become extremely specific in the context of sociocultural processes, including education in the field of culture and art.

Education in the field of culture and art in the context of globalization is positioned as a counteraction to the phenomena of mass art, a kind of spiritual practice of social being of modern man, saturated with humanistic ideals, which opposes the nullities of postmodern culture. The innovative concept of Ukraine's development aims at an organic combination of economic and social well-being with the education development and preservation of traditional culture in line with the world's leading trends. This actualizes the study of the Ukrainian education problems in the field of culture and art as a priority issue of the state cultural policy.

\section{Impact features of the globalization processes on education}

In recent decades, debates about the cultural implications of modern globalization have prompted the need for a careful study of the societal activity impact on the so-called periphery. Predictions about the inevitability of the homogeneous Western culture formation of the Western model due to

\footnotetext{
${ }^{1}$ Rozenberg, N.V. (2014). Nacional'nye kul'tury kak vyzov globalizacii. News of higher educational institutions. Volga region. Humanitarian sciences, 3 (31), 111-117.
} 
the global distribution of certain goods, customs and traits have now shifted to the concept that globalization in certain relationships does lead to homogenization, but does not deny local identification. The main characteristic of cultural globalization, according to the foreign researchers belief ( $\mathrm{Z}$. Bauman and others) ${ }^{2}$, is a continuous process of synthesizing the global and the local that is a process of glocalization in which the intangible and material attributes coming from outside are rethought and combined to form new syntheses. At the present stage, globalization processes are significantly accelerating and expanding, integrating into all sectors of society. At the same time, localization processes are developing at a faster pace and strengthening the local dimension in the economic, social and cultural spheres. In order to focus on the presence of these two apparently opposite trends, which allow a person to move smoothly from global to local dimensions, and vice versa, the term "glocalization" was introduced by foreign researchers.

According to modern dictionaries and reference books, the term "glocal" formed due to "global and local sublimation" and it is modeled on the Japanese word "dochakuka" (literal translation is the global union within local) that primarily meant the process of adapting technology to agriculture local conditions. In the scientific dimension, the term "global" was integrated by the researcher R. Robertson in the 1980's to define global localization. According to its interdisciplinary nature, it is defined as "the creation of products and services intended for the global market but adapted to local cultures"3. In turn, German researcher J. Blatter positions "glocalization" as "the simultaneous emergence of universalizing and specifying tendencies in modern social, political and economic systems", emphasizing that glocalization indicates that the increasing importance of the continental and global is growing in parallel with local and regional levels.

The term "globality" is the link and relationship between global and local elements, social aspects, and related issues (in particular, in terms of social justice, the global concept implies the provision of global knowledge according to the local context). The term is gaining widespread popularity in the late 1980s, and at the same time, in anthropology, the social sciences, and related fields, the same term is "indigenization" has spread, which has provoked a lengthy scientific debate. "Indigenization" is defined as "a form of

${ }^{2}$ Bauman, Z. (1998). On Glocalisation: Or Globalisation for Some, Localisation for Others. Thesis Eleven, 54, 37-49.

3 Robertson, R. (1995). Glocalization: Time-Space and Homogeneity-Heterogeneity. In M. Featherstone, S. Lash and R. Robertson (eds.) Global Modernities. London/Thousand Oaks/New Delhi, Sage, p. 28. 
cultural change in which traditional communities integrate elements of another into traditional culture" (a reverse process aimed at reviving traditional cultural elements in a new form is called "indigenization") ${ }^{4}$. In the context of the world political and socio-cultural processes, indigenization is defined as the desire of many countries and cultures, which in the past, through the impulse to modernize, have borrowed Western values and ideals, to return to their own cultural traditions and values. The same opinion is shared by the Ukrainian researcher I. Dotsyak, who believes that indigenization as a process of returning to "specific roots" is one of the ways of realizing the specific development of ethno-national processes caused by globalization ${ }^{5}$. Researcher on the example of ethnographic groups of Galicia proves the indisputable promotion of globalization impacts of the indigenization development in order to preserve national identity. According to I. Dotsyak, the revival of traditional culture is based on the restoration of identity $^{6}$. Thus, indigenization, as noted by German researcher B. HauserSchaublin, is often a reaction to confrontation with another culture, respectively, each process is a self-contained form of modernization that can apply to all elements of culture such as folklore, languages, customs, etc. ${ }^{7}$ Therefore, the level of demand for possible local specificity depends on the strength of globalization. Specifically, R. Robertson argues that the local and global trends "complement each other, and in some cases may lead to a clash between" ${ }^{\prime}$. Glocalization combines the modernization processes of local cultures with the achievements of a shaping global multicultural civilization.

M. Kozhevnikov and N. Pashkevich emphasize that the natural processes of development occur simultaneously in both sides of global and locality is globalization, therefore, leads to the fact that global is not a one-dimensional space, but a trans-locality, as the increasing approach of the poles of global and locality. Researchers point out that the term "globalism" is characterized by a specific strategy of combining local and global orientations and interests in politics, economy and culture, and therefore corresponds to the concept of

${ }^{4}$ Rietdorf, U. (2001). Minderheiten und ihre Bedeutung für endogene Entwicklungen in Afrika: das Beispiel Tansania. Verlag Dr. Kovač, Hamburg, p. 107.

${ }^{5}$ Dotsiak, I. (2017). Etnopolitychni protsesy na terytorii Halychyny v konteksti hlobalizatsii.

Proceedings. Institute of Political and Ethno-National Studies National Academy of Sciences of Ukraine, 1(87), p. 192.

${ }^{6}$ Ibid., p. 194.

${ }^{7}$ Hauser-Schäublin, B., Braukämper, U. (Hrsg.). (2002). Ethnologie der Globalisierung: Perspektiven kultureller Verflechtungen. D. Reimer, Berlin, p. 16.

8 Robertson, R. (1995). Glocalization: Time-Space and Homogeneity-Heterogeneity. In M. Featherstone, S. Lash and R. Robertson (eds.) Global Modernities. London/Thousand Oaks/New Delhi, Sage, p. 29-30. 
"new regionalism"9. The innovative phenomenon, unlike the old regionalism, with its protectionist orientation (introversion), implies the search for the best ways to integrate the member states of regional agreements into global processes. Therefore, globalization should not be understood as the preservation of traditional features, but their transition from the national to the global level, and most importantly the development at the regional and planetary levels.

According to the globalization concept, which implies a specific response to global processes, individual ethnos must identify their own culture and spirituality within the cross-cultural rhythmic interactions that ensure the intersection of national culture values with the spiritual orientations of the information society and the heritage of world culture masterpieces ${ }^{10}$. There is a complex network of links between economics, development and education, according to which globalization is positioned as a multifaceted phenomenon, affecting all industries, as each is important in the evolution of the other. In particular, education in the age of globalization, as A. Rolls points out, faces complex problems because, along with global migration, "new demographic realities and cultural entities are coming" ". According to M. Crossley ${ }^{12}$, these aspects (with varying degrees of variation) affect developing and developed countries.

In the latter, globalization is viewed in terms of modernizing the existing education system by improving and improvising knowledge-based exchanges of education systems in other countries. For example, by integrating the latest digital technologies into the educational process, USA or Latin American students participate in video conferencing with students in Canada or Western European countries. Thus, globalization in the education system is manifested in particular through technology, and facilitates the sharing of global knowledge. On the other hand, an important aspect of the issue is the assimilation into the educational system of developed countries of immigrants are in this case, in the process of cultural exchange, the norms of the culture of the host country, with emphasis on integration and compliance, are dominant ${ }^{13}$.

${ }^{9}$ Kozhevnikov, N.N., Pashkevich, N.L. (2005). Glokalizaciya koncepcii harakternye cherty prakticheskie aspekty. Bulletin of Yakutsk State University, 3, p. 111.

${ }^{10}$ Ibid., p. 112.

${ }^{11}$ Rolls, A. (2007). International perspectives on education. Bronx, NY: H.W. Wilson Co.

${ }^{12}$ Crossley, M. (2002). Comparative and International Education: Contemporary Challenges, Reconceptualization and New Directions for the Field. Current Issues in Comparative Education. Teachers College, Columbia University, 4(2), p. 81.

${ }^{13}$ Chinnammai, S. (2005). Effects of globalisation on education and culture. In ICDE International Conference. Madras, India: University of Madras, p. 2. 
F. Patel, exploring the specifics of the globalization of higher education, emphasizes that the paradigm of internationalization, which most educational institutions aspire to, and which certainly influences aspects of education and research, is based solely on Western systems of knowledge that underestimate and deprive opportunities of scale dissemination of other forms of knowledge. The scholar defines the internationalization of higher education as "a skillfully designed apparatus designed to generate significant profits with limited focus on context-oriented solutions or sustainable social change that impedes the development of local communities"14, and also calls for the restructuring of this concept in favor of the education glocalization, justice and inclusivity, which should contribute to the legitimacy of various forms of knowledge, respect for cultural traditions.

Glocalization seeks to combine local and universal values, putting them in a familiar context, and given the globalization complexities, which is characterized by problems in its limited outlook. Unfortunately, universal standards for global education have not yet been developed, but many scholars, institutions and organizations are offering diverse approaches:

- how educational institutions convey an understanding of the global realities, opportunities and challenges of the local context;

- how schools fulfill the mission of meeting local needs, addressing global realities and acting at the level of global aspirations ${ }^{15}$.

According to $\mathrm{H}$. Lynch and F. Patel, the glocalization of learning and teaching involves the consideration of curricula and the formation of a pedagogical link between the local and global communities in terms of social responsibility, justice and sustainability ${ }^{16}$. Researchers say that glocalization can help reduce the impact of local and global socio-economic, cultural, political and other issues through dialogue and action, while creating unique learning experiences for learning communities at the local and global levels. For example, in developed countries, such as Australia and Canada, the discourse on the globalization of higher education, focusing on life skills, employment opportunities and civil liability as desirable attributes, defines effective strategies for preparing graduates for their future role as professionals in the global environment. These attributes intersect with the

${ }^{14}$ Patel, F. (2017). Internationalization of HE Needs to be Replaced. University World News. URL: https://www.universityworldnews.com/post.php?story=20170927101224475.

15 Niemczyk, E.K. (2019). Glocal Education in Practice: Teaching, Researching, and Citizenship. In BCES Conference Books, 17. Sofia: Bulgarian Comparative Education Society, p. 14.

${ }^{16}$ Patel, F., Lynch, H. (2013). Glocalization as an Alternative to Internationalization in Higher Education: Embedding Positive Glocal Learning Perspectives. International Journal of Teaching and Learning in Higher Education, 25(2), p. 223. 
aspirations of young people to acquire intellectual and professional qualifications, as well as to acquire interpersonal skills and meet diverse needs in accordance with the trends of socio-cultural space: "Emphasis is placed on the of professionals' development who are responsive to local and global issues along with the changing needs of socio-economic trends with their typical principles of social responsibility and justice"17.

Thus, in line with H. Lynch and F. Patel's theory, globalization in the context of higher education implies a positive learning experience thanks to a respectful attitude towards cultural values. The Glocalation Dialogue aims to bring students beyond the boundaries of intercultural communication while at the same time obliging participants in the learning process to reflect on actions that demonstrate an in-depth understanding and recognition of the benefits, differences and similarities between different cultures. In this context, globalization is seen as a paradigm of empowerment.

\section{Education glocalization in the field of culture and art}

The glocalization concept of education in the field of culture and the arts is focused on the combination of global and local contexts in the teaching process. Its specific characteristic is the dominance of the conceptualization of local experience with the aim of establishing mental connections between local and global processes.

The sublimation of local and global resources in the education system, according to Austrian and German researchers, the staff of Leuphana Universität Lüneburg and the Konrad Lorenz Institute for Evolution and Cognition Research, cooperation and knowledge production. Researchers say this process overcomes social, geographical and cultural boundaries and includes a means by which learners learn about the world and take action in it $^{18}$. Accordingly, the term "global" should also be used to refer to a new sector of students "who have global aspirations, but for certain objective and subjective reasons should remain locally"19. Representatives of this sector aspire to become globally competent, but for various reasons, such as due to family circumstances, financial constraints or lack of academic performance, they cannot obtain education in leading capital institutions of higher education or abroad.

${ }^{17}$ Patel, F., Lynch, H. (2013). Glocalization as an Alternative to Internationalization in Higher Education: Embedding Positive Glocal Learning Perspectives. International Journal of Teaching and Learning in Higher Education, 25(2), p. 225.

${ }^{18}$ Caniglia, G., Bellina, L., Lang, D.J., Laubichler, M. (2017). The Glocal Curriculum: A Practical Guide to Teaching and Learning in an Interconnected World. Baden-Baden: Critical Aesthetics Publishing.

19 Niemczyk, E.K. (2019). Glocal Education in Practice: Teaching, Researching, and Citizenship. In BCES Conference Books, 17. Sofia: Bulgarian Comparative Education Society, p. 14. 
Thus, global students are choosing to benefit from a quality global education that will further their desired employment and career development at the local level. However, local uniqueness, personality, culture, place and region, as well as interpersonal contacts on the ground are extremely important for understanding, understanding and responding to external, global forces. Much more complex is the issue of cultural and arts education in developing countries. As information sharing is now an accessible phenomenon, the demands of the globalized world on the citizens of developing countries are noticeably increasing, thus globalization is positioned as a transformative force.

M. Quieck, exploring the social and cultural dimensions of higher education transformation in Central and Eastern Europe, identifies the major global factors contributing to the transformation of higher education:

- the destruction of the role of the state in socio-economic development with its vision of higher education as a national property, which contributes to the strengthening of national consciousness;

- the functions reformulation of the state, including state-funded government-funded measures;

- the invasion of economic rationality and corporate culture into the public sector globally ${ }^{20}$.

Important factors influencing the formation of the situation in the education system in the field of culture and art are: innovative technologies, forming of student communities, new trends in higher education. Trends in the contemporary socio-cultural space require specific (changing, not fragmented) understanding and understanding of society and social issues. For example, the Government of Finland approved in 2016 the decision to introduce an innovative education system in the country by 2020, according to which schools are taught not a subject but a phenomenon. So-called Phenomenonbased learning is a multidisciplinary, constructivist form of learning whereby, unlike a subject-oriented approach, students and students learn a specific topic or concept as a whole. The new concept builds on real-world experience that reflects the interconnection of subjects and contexts. The main features of this training form are:

- providing processes in which new information lays on a particular issue, issue, or phenomenon (facilitates better assimilation of material);

- creating a deep learning environment is cognitive processes in the Phenomenon-based learning environment are typical of the subject being studied or skills that are formed in the learning process to real life situations;

${ }^{20}$ Kwiek, M. (2001). Social and Cultural Dimensions of the Transformation of Higher Education in Central and Eastern Europe. Higher Education in Europe, XXVI, 3, 399-410. DOI: 10.1080/03797720120115979. 
- positioning the student with an active form of knowledge and information (constructivist form of education).

Since the foundation of global education is based on the study of global and local ties in order to maximize global consciousness, this phenomenon, according to E. Nimchuk, should be considered in terms of dual citizenship, accompanied by certain privileges and responsibilities: "we are all citizens of a particular nation, as well as the citizens of the world who are pursuing a common goal is to understand and support the world in which we live" ${ }^{21}$, and therefore, global education is designed to provide the ability to know oneself in the context of narratives of engagement with the world and local realities ${ }^{22}$.

Glocalization involves the sublimation, adaptation, and combination of two or more processes, one of which must be local. Although, in the context of cultural and art education, glocalization can acquire hybrid features. For example, a hybrid version of higher education in Singapore incorporates original American and British models are two different systems combined for best results. However, in the context of national cultural and arts education, a meaningful approach to glocalization involves the inclusion of at least one component of the local culture, value system and practice. Undoubtedly, in the context of the globalization processes of the 21 st century global influences cannot be ignored, but positioning and localization cannot be predicted.

Modification of international templates according to national conditions instead of automatic copying is now known practice of "re-contextualization", was proposed by foreign researchers D. Dakovsky and R. Harmsen in $2015^{23}$. For example, within the framework of integrating into the higher education system of the positive experience of Western European countries, considerable attention at the present stage is paid to dual education as one of the three main forms of education in Ukraine (together with institutional and individual) since $2017^{24}$. This priority area provides:

- rethinking their own strategies for curriculum development and institutional policy in the context of the specifics of the teaching of artistic disciplines (in particular, these are special theoretical-practical courses, which

${ }^{21}$ Niemczyk, E.K. (2019). Glocal Education in Practice: Teaching, Researching, and Citizenship. In BCES Conference Books, 17. Sofia: Bulgarian Comparative Education Society, p. 14.

${ }^{22}$ Ibid.

${ }^{23}$ Dakowska, D., Harmsen, R. (2015). Laboratories of reform? The Europeanisation of higher education in Central and Eastern Europe. European Journal of Higher Education. Europeanisation, internationalization and higher education reforms in Central and Eastern Europe, 5(1), p. 6-7.

${ }^{24}$ Zakon Ukrainy Pro osvitu : pryiniatyi 05 ver. 2017 roku № 2145-VIII. (2017). Information of the Verkhovna Rada, 38-39, 380. 
provide for improving the level of training at the theoretical level, significant improvement of the practical and aimed facilitating the further employment process, etc.);

- organic integration of certain elements of international programs into the national educational process, characterized by the synthesis of fundamental, rational and artistic features in the field of culture and art, dominance of belonging to the national academic / vocational school.

The main purpose of developing contemporary curricula in the field of culture and the arts is to provide the process of providing students with a holistic, interconnected, clear and consistent experience that is relevant to their personal and professional development. In developing curricula in accordance with the concept of glocalization, it is important to: systematically update the content being taught and update it globally and locally; taking into account the individual qualities of students, their motivation, experience and more. This requirement is dictated by the fact that no system of knowledge is ideal or most acceptable in today's complex sociocultural context. Although the "global" notion implies certain standardization, global education can contribute to the development of leading teaching methods and offer a comprehensive perspective on the integrated nature of the local and global.

According to $\mathrm{K}$. Walhuther, Comparative Education can provide additional insights into understanding the value of global education, exploring opportunities, problems, and identifying best practices ${ }^{25}$. Comparative education plays an auxiliary and informative role - exploring aspects of different education systems, it takes into account the relevant (local) social contexts through which these educational systems were formed. According to $\mathrm{K}$. Wolhuter, the focus of comparative education goes beyond the focus of the education system as such, since the latter is studied in a social context and viewed as being shaped or the result of a social force (e.g., cultural, economic, political, demographic, geographic, social, etc. $)^{26}$. Accordingly, in the process of identifying and integrating best practices from one context to another, many social, cultural, environmental variables need to be considered. Sharing the opinion of some scholars (K. Mandi, K. Bickmore, R. Heiho, M. Medden, etc.), it should be noted that globalization has challenged the traditional understanding of comparative education at the level of national education systems.

${ }^{25}$ Wolhuter, C.C. (2018). Leading the Way to Impact-Making Research: The Role of Comparative International Perspectives in Research on Leadership in Education in South Africa. In C.C. Wolhuter (Ed.) Raising the Impact of Education Research in Africa. Cape Town: AOSIS (pp. 21-40).

${ }^{26}$ Ibid. 
Quality management of vocational and cultural training is positioned as a major factor providing benefits to any system, including the education system at the global level. In accordance with the specifics of the education system in the field of culture and art, in higher education institutions it is extremely important to combine the process of vocational training and teaching of general cultural disciplines. Accepted and integrated global values in the system of education in the field of culture and art of Ukraine contribute to the establishment of intercultural dialogue, the purpose of which is the evolution of aesthetic principles and artistic and creative process, as well as enhancing the manifestation of the author's individuality. However, the implementation and realization of the globalization concept in Ukraine is complicated, first of all, by the shortcomings of the administrative and legal status of educational institutions (art schools, colleges and institutions of higher education) and their affiliation with different departments (respectively, and tangible differences in financial security). At the local and regional levels, these shortcomings are manifested by the lack of the required number of cultural and art education institutions, including the absence of higher vocational education institutions for certain specialties (in particular, choreographic, fine arts, theater, etc.), which in turn creates the prerequisites for local staff shortages in this area. Complicating circumstances is the lack of motivation for the graduate to return to work in their specialty in their native town.

The implementation and popularization of the global education concept in the culture field and the arts should help to encourage research into the teaching staff and students of local and global perspectives in order to broaden and enrich the positive learning experience. In the context of the national higher education system, this concept implies giving potential graduates the opportunity to become active participants in the creative industry of postindustrial society.

\section{CONCLUSIONS}

One of the characteristic features of the education system in the culture field and art is constant changes in accordance with the transformation processes of the socio-cultural space, aimed at its modernization and compliance with the strategy of social development. As an important part of the cultural policy in modern society, the sphere of education in the field of culture and art is a complex, multidimensional and open system that contributes to the formation and the inner world development of man, the creative potential of the individual, his intellect and emotional component due to mastering a set of specific competencies; organic transfer, assimilation and 
preservation of spiritual values in the process of enculturation in order to ensure the harmonious development of society.

Essential for education in the field of culture and art in Ukraine is the implementation of the "think globally, act locally" principle, which leads to the expediency of a recoding kind of the structural modification of educational processes on the principles of glocalization. Accordingly, higher education in the field of culture and art in Ukraine in the early 2020's should meet the leading global trends, while preserving and enhancing the national character of Ukrainian culture. It should be remembered that the thoughtless borrowing of Western educational theories and practices generates a peculiar cultural divide, which causes a violation of the traditionalism of the structural and functional approach to education in the field of culture and art, which results in the loss of ethno-cultural identity.

Modern globalization processes shape the specificity and dynamics of the development of education in the field of culture and art, as they simultaneously affect the inter-ethnic relations and essential components of the structure of the Ukrainian people. Characteristic tendencies of mastering Western models (for example, dual education) and values are the manifestation of so-called "Westernization", while striving for the establishment of local self-identification and restoration of traditional values; it is a manifestation of glocalization or indigenization. Accordingly, in the context of contemporary transformation processes in the education system in the field of culture and art, it is extremely important to shift the emphasis from globalization to globalization concept and there is meaningful integration into the national educational process of the most appropriate elements of international programs. Unlike the dissemination of individual cultural elements, this concept is characterized by a comprehensive rethinking of the new, in order to preserve and enhance cultural identity in the innovative strategies context.

\section{SUMMARY}

The globalization processes influence on the education development in the field of culture and art in Ukraine has been characterized, a comparative analysis of existing world models of higher education has been made. The specifics of the national education development in the field of culture and art as a complex socio-cultural phenomenon have been identified and its specific characteristics in the conditions of glocalization have been determined. It is emphasized that education in the culture field and art in Ukraine, as a fundamental component of development, should adapt to the changes characteristic of the current stage of the world community development. The study has found that the globalization, sublimation and blending of global and 
local contexts in accordance with the specifics of national education in the field of culture and art, while preserving the differences and significant contribution of different cultural communities, promotes the intercultural dialogue establishment, the aim of which is the creative evolution principle process, as well as the promotion of the author's individuality. It is emphasized that the characteristic tendencies of mastering Western models (for example, dual education) and values are the manifestation of the so-called "Westernization", while the desire to establish local self-identification and restoration of traditional values, it is a manifestation of glocalization or indigenization. It is concluded that in the context of modern transformation processes in the education system in the field of culture and art it is extremely important to shift the emphasis from globalization to glocalization concept it is meaningful integration into the national educational process of the most appropriate elements of international programs.

\section{REFERENCES}

1. Bauman, Z. (1998). On Glocalisation: Or Globalisation for Some, Localisation for Others. Thesis Eleven, 54, 37-49.

2. Blatter, J. (2013). Glocalization. In Encyclopedia Britannica. URL: https://www.britannica.com/topic/glocalization.

3. Caniglia, G., Bellina, L., Lang, D.J., Laubichler, M. (2017). The Glocal Curriculum: A Practical Guide to Teaching and Learning in an Interconnected World. Baden-Baden: Critical Aesthetics Publishing.

4. Chinnammai, S. (2005). Effects of globalisation on education and culture. In ICDE International Conference. Madras, India: University of Madras (pp. 1-6).

5. Crossley, M. (2002). Comparative and International Education: Contemporary Challenges, Reconceptualization and New Directions for the Field. Current Issues in Comparative Education. Teachers College, Columbia University, 4(2), 81-86.

6. Dakowska, D., Harmsen, R. (2015). Laboratories of reform? The Europeanisation of higher education in Central and Eastern Europe. European Journal of Higher Education. Europeanisation, internationalization and higher education reforms in Central and Eastern Europe, 5(1), 4-17.

7. Dotsiak, I. (2017). Etnopolitychni protsesy na terytorii Halychyny v konteksti hlobalizatsii. Proceedings. Institute of Political and Ethno-National Studies National Academy of Sciences of Ukraine, 1(87), 190-198.

8. Hauser-Schäublin, B., Braukämper, U. (Hrsg.). (2002). Ethnologie der Globalisierung: Perspektiven kultureller Verflechtungen. D. Reimer, Berlin.

9. Kozhevnikov, N.N., Pashkevich, N.L. (2005). Glokalizaciya koncepcii harakternye cherty prakticheskie aspekty. Bulletin of Yakutsk State University, $3,111-115$. 
10. Kwiek, M. (2001). Social and Cultural Dimensions of the Transformation of Higher Education in Central and Eastern Europe. Higher Education in Europe, XXVI, 3, 399-410. DOI: 10.1080/03797720120115979.

11. Niemczyk, E.K. (2019). Glocal Education in Practice: Teaching, Researching, and Citizenship. In BCES Conference Books, 17. Sofia: Bulgarian Comparative Education Society (pp. 11-18).

12. Patel, F. (2017). Internationalization of HE Needs to be Replaced. University World News. URL: https://www.universityworldnews.com/ post.php?story=20170927101224475.

13. Patel, F., Lynch, H. (2013). Glocalization as an Alternative to Internationalization in Higher Education: Embedding Positive Glocal Learning Perspectives. International Journal of Teaching and Learning in Higher Education, 25(2), 223-230.

14. Rietdorf, U. (2001). Minderheiten und ihre Bedeutung für endogene Entwicklungen in Afrika: das Beispiel Tansania. Verlag Dr. Kovač, Hamburg.

15. Robertson, R. (1995). Glocalization: Time-Space and HomogeneityHeterogeneity. In M. Featherstone, S. Lash and R. Robertson (eds.) Global Modernities. London/Thousand Oaks/New Delhi, Sage (pp. 25-44).

16. Rolls, A. (2007). International perspectives on education. Bronx, NY: H.W. Wilson Co.

17. Rozenberg, N.V. (2014). Nacional'nye kul'tury kak vyzov globalizacii. News of higher educational institutions. Volga region. Humanitarian sciences, 3 (31), 111-117.

18. Wolhuter, C.C. (2018). Leading the Way to Impact-Making Research: The Role of Comparative International Perspectives in Research on Leadership in Education in South Africa. In C.C. Wolhuter (Ed.) Raising the Impact of Education Research in Africa. Cape Town: AOSIS (pp. 21-40).

19. Zakon Ukrainy Pro osvitu : pryiniatyi 05 ver. 2017 roku № 2145-VIII. (2017). Information of the Verkhovna Rada, 38-39, 380.

\section{Information about the author: Mykhailo Poplavskyi,}

Doctor of Pedagogical Sciences, Professor, Head of the PR and Journalism Department, Kyiv National University of Culture and Arts, 36, Y. Konovalets str., Kyiv, 01133, Ukraine http://orcid.org/0000-0002-8234-8-064 


\section{INNOVATION CULTURE AS A CHARACTERISTIC OF PERSONALITY AND FORM OF MODERN CULTURE, ITS ESSENTIAL FEATURES}

\section{Kateryna Kyrylenko}

\section{INTRODUCTION}

The term "innovation culture" has recently been used in the scientific literature as well as in the everyday language. Mostly innovation culture is interpreted by scholars of different fields of knowledge as a personal characteristic of a human, which is connected with their professional development (Ye. Afanasieva, N. Ilina, O. Koiuda, V. Kremen, Ye. Lisin, R. Milenkova, T. Sobol, B. Santo and others). The modern motivational literature (T. Wagner, P. Diamandis, S. Kotler, K. Christensen, S. Covey and others) pays considerable attention to the formation of innovation culture. However, in the works of researchers there is a tendency to highlight innovation culture as one of the defining characteristics of modern culture (K. Robinson, R. Florida and others).

The term "innovation culture" is derived from the term "innovation". It should be noted that the term "innovation" is not identical to the term "novation". Innovations are products of modernity and they emerge in industrial society. Novations take place in any historical period, they have an impact on the development of each culture at a certain stage of its development. Novation can be the subject of innovation. However, it is not necessary even in the modern world. According to E. Rogers, one of the most authoritative modern researchers of the spread of innovations, innovation is not just some idea, solution or object that contains a certain novelty. This is a novelty that receives recognition and usage, and is being shared and implemented. At the beginning of his book "Diffusion of Innovations", the researcher pays attention to conspicuous fact: A. Dvorak keyboard layout, the use of which hasten the transcription on a computer, has not become an innovation, despite its undoubted benefit.

Innovation needs innovators, those who implement and consume it, it needs people with a high level of innovation culture.

The concept of "innovation culture" is now actively used in the sociopolitical context, it is developed in the scientific literature.

${ }^{1}$ Rodzhers Everett, M. (2009). Dyfuzija innovacij. Kyiv: Kyjevo-Moghyljansjka Akademija, pp. 28-30. 


\section{Approaches to defining the term "innovation culture"}

The term "innovation culture" is used in a number of European documents. In particular, in the document entitled "Green Paper on Innovation", which was developed by the European Commission in December 1995. In the document, innovation is regarded as synonymous with successful production, assimilation and use of innovations in economic and social fields. It offers new solutions to problems, and makes it possible to meet the needs of individual and society as a whole. There are many examples of this: the development of vaccines and medicaments, the improvement of transport safety (the emergence of ABS systems, airbags), the emergence of convenient means of communication (cell phones, video conferencing), increased access to know-how (CD-ROM, multimedia), the emergence of new methods of marketing (home banking), improved working conditions, the development of environmentally friendly technology, more efficient public services etc. According to the document, the antonym for the term "innovation" is "archaism and routine". That is why innovation faces a lot of obstacles and such stiff resistance. That is why, "the development and sharing an innovation culture", the document notes, "is becoming a decisive challenge for European societies"

Another document entitled "The First Action Plan for Innovation in Europe" identifies three priority areas for action for the European community: 1) to foster a genuine innovation culture (this area is highlighted as the top priority); 2) to set up a legal, regulatory and financial framework conducive to innovation; 3 ) to gear research more closely to innovation at both national and community level. The document uses the term "genuine innovation culture", it requires such an attitude of the individual to the world, such outlook and life guidelines, which would combine "creativity, entrepreneurship, willingness to take calculated risks and acceptance social, geographical or professional mobility. Being innovative also demands an ability to anticipate needs, rigorous organization and a capacity for meeting deadlines and controlling costs" ". The document refers to the need to encourage the innovative mentality of modern person. Means to act to implement this guideline are: "education and training; easier mobility for researchers and engineers to firms; demonstrate effective approaches to innovation in the economy and in society; propagate the best management and organizational methods amongst businesses; stimulate innovation in the public sector and in government" ${ }^{\prime 4}$.

${ }^{2}$ Green Paper on Innovation. European Union. URL: http://europa.eu/documents/comm/ green_papers/pdf/com95_688_en.pdf.

${ }^{3}$ The First Action Plan for Innovation in Europe - Innovation for growth and employment. Publications Office of the European Union. URL: https://op.europa.eu/en/publication-detail/-/ publication/c1944d2d-b791-4e11-bc42-75c5b6f8ff35/language-en.

${ }^{4}$ Ibid. 
In the study of the European Commission's project "TRANSFORM" (this project deals with the impact of information and communication technologies on the economy and society) called "Transformation of Regional Societies Through ICTs: State(s) of the Art(s)" (2006), the concept of "regional innovation culture" is introduced and it is stated that "regional innovation cultures sit within larger cultural entities (and interact with more territorially dispersed organizational forms, each with its own culture)" Another "TRANSFORM" study called "Differences in Innovation Culture Across Europe" (2008) examines the theories that explain the differences in regional innovation cultures and the impact of regional innovation cultures for economic and social progress ${ }^{6}$. "Innovation culture" in the study is understood in terms of attitude to innovations, technology, knowledge sharing, entrepreneurship, business.

In the scientific literature the term "innovation culture" is interpreted as a culture of attitude to innovations, a culture of their consumption and production. Later, the term "innovation culture" gets a broader interpretation. Innovation culture means the characteristic of a person as a professional in a certain field, which determines their willingness to develop and improve. Innovation culture begins to be understood as a characteristic of a person, which determines their willingness to perceive and produce new things both at the level of everyday life and at the level of professional activity. Innovation culture is a property not only of individuals, but also of groups of people, organizations they work for, and of the entire society.

American economist, professor at the University of Toronto Richard Florida, relying on other researchers (including Joel Mokyr) ${ }^{7}$, writes about the emergence of a new class of people called "Homo creativus". "The mutual commitment to the spirit of creativity in all its variety is precisely what underpins the new creative ethos that is driving our era" "We can and must move from senseless growth (the Industrial Age) to smart growth (the Creative Era), based on use of all human capabilities, that would make us happier, make more impressions, and fill our lives with meaning, not just more material products",

\footnotetext{
${ }^{5}$ Transformation of Regional Societies Through ICTs: State(s) of the Art(s). TRANSFORM. URL: http://www.transform-eu.org/publications/ documents/d1.1_website.pdf.

6 Differences in Innovation Culture Across Europe. TRANSFORM. URL: http:// transform-eu.org/publications/documents/Differences\%20in\%20Innovation\%20Culture.pdf. p. 74.

${ }^{7}$ Floryda, R. (2018). Homo creativus. Jak novyj klas zavojovuje svit. Kyiv: Nash format,

${ }^{8}$ Ibid., p. 29.

${ }^{9}$ Ibid., p. 362.
} 
We believe that innovation culture can be defined as follows: it is a characteristic and component of a general cultural process that determines the degree of perception by an individual, group or society of different novelty in the range of its transformation into innovations.

Numerous definitions of innovation culture, which take place in the scientific literature, can be grouped and the following approaches to their understanding can be distinguished: 1) innovation culture as a degree of implementation of novelty by different historical types of culture (though such an interpretation does not convey the essence of innovation culture; it is more correct to use the phrase "the culture of novelty"); 2) innovation culture as a personal (as well as professional) characteristic of a modern human in the context of their willingness to introduce and produce something new both in a certain field of professional activity and in everyday life; 3) innovation culture as a methodological basis for the improvement and modernization of all spheres of human activity; and, finally, the most extensive and the newest interpretation: 4) innovation culture as a form of modern culture, a new historical reality that has emerged as a result of the transformation of industrial society towards a post-industrial, informational and innovative one, as a result of the particular role of innovations in it.

These approaches clearly distinguish two vectors for understanding the concept: innovation culture as an integral characteristic of the person (or other subject: organization, corporation, institution etc.) and innovation culture as a characteristic and form of modern culture ${ }^{10}$.

Innovation culture as a characteristic of the modern person determines their ability to live in the conditions of constant changes and permanent renewal, readiness for the acquisition of innovations (from tolerant attitude to use and implementation), openness to permanent learning, ability to produce new things. People with a high level of innovation culture are creative, capable of lifelong learning; they are ready not only for perception, assimilation, use of innovations, but also for their creation. An innovation culture of personality can and must be developed in the modern world.

The level of development of an innovation culture of personality is determined by the nature of its attitude to innovations. Everett Rogers is an American sociologist, author of "Diffusion of Innovations" (1962), which has had several reissues and several revised editions during five decades (1971, 1983, 1995, 2006), described psychological portraits of consumers of innovations, based on the level of development of their innovation culture from the highest to the lowest rate of its adoption. Rogers notes that $2.5 \%$ of

${ }^{10}$ Kyrylenko, K., Kunderevych, O., Bojko, L. (2018). Filosofija kuljtury: slovnyk. Kyiv: TOV “Aghentstvo Ukrajina”, p. 71. 
people have a high level of innovation culture, and they are the first who implement innovation (they are "innovators" or trendsetters). $13.5 \%$ of people researcher calls "early adopters". They are people who are ready for something new that has already been partially tested, but has not become rolled-out yet (these people have authority in society, others pay heed to them). The so-called "early majority" and "late majority" have $34 \%$ each they are those who try to keep up with others in their pursuit of the "spirit of the times". About $16 \%$ of people are "laggards", late adepts, they are more conservatives than innovators, but they use the innovation that is widely acknowledged and evident ${ }^{11}$.

An innovative culture of personality is defined as "innovativeness" (the term "creativity" is also used synonymously). Innovativeness characterizes people in their pursuit to creative self-realization in the process of both professional activity and vital self-determination. Innovativeness is a trait of a person, which implies a creative, non-standard, innovative approach to different life situations in different spheres of life, the ability to overcome the commonplaceness, stereotypeness, amorphousness and inertia in creating of something new or developing an existing one. Innovativeness is a consequence of the developed innovation intelligence, the formed innovative thinking, the willingness to innovation activity.

In recent years, the concept of innovation culture has increasingly been used as a characteristic of modern society and its type of culture (T. Wagner, P. Diamandis, J. Mokyr, K. Robinson, R. Florida, etc.). A significant influence on the formation of such an interpretation of innovation culture was made by studies in pedagogy, where the authors raised the question of the relevance of modern education to the needs of modern society and stated the need for the formation of new educational standards. "Nineteenth-century educational ideologies do not succeed in overcoming the challenges of the twenty-first century. We need a new Renaissance that will value different types of intelligence and nurture creative relationships between disciplines as well as between education, business and the general public" - Ken Robinson notes ${ }^{12}$.

The understanding of innovation culture as a form of modern culture is reasonable, because the concept of "the form of culture" refers to a particular cultural product, the technologies by which it is created, and the ideological and methodological principles on which it is based; their core is the outlook inherent in this culture ${ }^{13}$.

${ }^{11}$ Rodzhers Everett, M. (2009). Dyfuzija innovacij. Kyiv: Kyjevo-Moghyljansjka Akademija, p. 313.

${ }^{12}$ Robinson, K. (2017). Osvita proty talantu. Syla tvorchosti. Lviv: Litopys, p. 230.

${ }^{13}$ Levit, S.Ya. (ed.) (1998). Kul'turologiya. XX vek. Entsiklopediya: v 2 t. Saint Petersburg: Universitetskaya kniga; OOO "Aleteyya". URL: http://yanko.lib.ru/books/cultur/culturology 20century2volumes1998sl.htm\#_Toc299572017/. 
Innovation culture as a form of modern culture creates its cultural product, produces technologies by which its artifacts are created, shapes ideological and methodological values, its vision of the world and human. It simulates such a picture of the world, which is the course of a large number of nonlinear processes (it can be recognized by the means of synergetics). Innovation culture as a form of modern culture forms a new (innovative) type of person, appropriate (innovative) content of modernity. It correlates with such modern concepts as post-industrial society and information culture. Innovation culture is antithetical to mass culture in post-industrial society. The emergence of the Internet and the processes of digitalization that are currently active are the result of the creation of an innovation culture.

Scientific discourse evolves from understanding the term "innovation culture" as a characteristic of the individual to its interpretation as a form of modern culture.

An innovation culture, interpreted either as a characteristic of the individual or as a form of modern culture, has end-to-end characteristics. The essential features of innovation culture are dialectical unity: traditions and innovations (vertical or diachronic section), humanitarian and natural science knowledge (and forms of culture) - (horizontal or synchronous section), which is embodied in creative form in the process of creative realization of new ideas. These ideas arise as a result of the people's perception of the world as an open nonlinear system capable of producing something new (such a picture of the world is described by synergetics - the science of the development of nonlinear systems). Therefore, innovation culture has a fundamental integrity as its cornerstone. It is focused on creating of something new by taking into account the progressive modernity, while preserving the achievements of the past. Innovation culture is aimed at combining natural science and humanitarian knowledge, at combining rational and intuitive in the direction of forming a new integral innovative (evolutionary-synergetic) picture of the world.

\section{Diachronic section of innovation culture: unity of tradition and innovation as a characteristic of innovation culture}

The unity of tradition and innovation, past, present and future in the content of innovation was pointed out by American scientist Peter Drucker ${ }^{14}$. Innovation offers such a "new", which is not a denial of the existing one, but its improvement; in addition, it needs to be copied and used, which is possible only if it is tested, assimilated, processed when it becomes such a new that is

${ }^{14}$ Drucker, P. (2001). Management Challenges for the 21st Century. New York: Harper Business. 
already habitual or traditional. Innovation does not remain an innovation for a long time, it tends to be a modern tradition, and eventually it naturally becomes. The term "tradition" comes from Latin "tradition" and means "transmission". Innovation is the "introduction" of the new both into the wide environment of replication-use, and in the tradition itself (any tradition emerges initially as innovation). Therefore, innovations arise in the depths of tradition and involves communication with it.

The tradition that emerges as a way of being and reproducing the cultural heritage, as a cross-cutting line of the cultural evolution of mankind, and the innovation that arises as the intention to offer something fundamentally different, are presented in every historical epoch, in each certain phenomenon of culture, in every individual. Various cultural and philosophical paradigms, as well as certain periods of development of human history within these paradigms, have had primacy over tradition and innovation. In particular, the Oriental paradigm of philosophizing has always preferred tradition over innovation, has cultivated the preservation, study, and reproduction of tradition. However, the current socio-political success of the countries that are its prime representatives - for example, China - demonstrates that this commitment to tradition has a strong potential to find the new, interesting innovative ideas and solutions. The Western paradigm of philosophizing prefers innovation, and each new period of time must go beyond the achievements of the previous one. However, a closer examination of evolutionary processes within the emergence of Western type of philosophizing shows the close and deep-rooted interconnections of different epochs. The most striking example of distinguishing one epoch from the achievements of another one that led to temporary interruption of historical progress is the critical attitude of the Renaissance humanists to the medieval inheritance, which Hegel later proclaimed as "the abyss of human history", "the Dark ages" in the history of mankind ${ }^{15}$. However, it is precisely from the philosophical heritage of the Middle Ages the distinction between religious and secular knowledge (the theory of Averroism or the double truth of Ibn Rushd), espoused by humanists, originates; proclaiming God as an "absolute maximum" (Nicholas of Cusa) was not intended to diminish his significance, but to determine the greatness and unknowability of his essence, etc. The eloquent image of the dialogue of the other two epochs - the Middle Ages and Antiquity - is suggested by J. Le Goff in his famous work "Medieval Civilization"16 : thinkers of the Middle Ages seem to continue to weave the fabric, which the thinkers of

\footnotetext{
${ }^{15}$ Gegel', G.V.F. (1993-1994). Lektsii po istorii filosofii. Saint Petersburg: Nauka.

${ }^{16}$ Le Goff, Zh. (1992). Tsivilizatsiya srednevekovogo Zapada. URL: https://www.gumer.info/ bibliotek_Buks/ History/Goff/index.php.
} 
Antiquity put into the loom; indeed, without the philosophical heritage of Plato and Aristotle, and the ongoing debate between their ideas, it is impossible to understand the search of the essence of universals made by the scholastics, and the controversy about universals has become the core of the entire period of scholastic philosophizing of the Middle Ages.

In tradition you can follow some of the defining characteristics of it. First of all, repetitiveness, as long as tradition must be reproduced, fixed, and have as many reproductions as possible. In addition, tradition is always selective, it refers not to the logical-theoretical mind, but to the so-called "motivational component of the consciousness of the individual"17, because tradition is not the realization of structural components (such as human thought), but the choice and assimilation after conscious study and the processing of some material borrowed from the outside (if it is an individual tradition, then the individual's prior experience will be such an external context). Tradition is also characterized by polysemy, it can be assimilated and interpreted differently. In the tradition, there is some "authoritarianism" in the context of the presence and dominance of authorities (external or internal), whose opinion is always a determining factor for assimilating the tradition (it is needed to distinguish between a tradition that is of a spontaneous nature, its certain characteristics are presented implicitly and it can hardly be considered a tradition in the full philosophical meaning, and a tradition that is a conscious elaboration and assimilation of previous cultural content and forms). Tradition always accumulates a certain "code" of the previous culture (its system of norms, customs, outlook principles and values, etc.), this coding system can occur either by the Euclidean geometry model, when only the main is assimilated, or by the model of the oriental type of culture broadcasting, when attention is paid to the special and atypical, but such coding always takes place. Tradition emerges as the mediator, the conductor of cultural content and the cultural core of humanity, it is a communicator between generations, the archiver of experience, the framework for action is passed to future generations from their predecessors through tradition as a question that has not been answered yet. Tradition, in the simplest way, reproduces itself through customs, ceremonies, rituals, which are easily learned and regularly reinforced through repeated actions and duplications.

Innovation is the creation of something new, search for something that did not exist before. The problem of the creation of the new has repeatedly been the subject of study of both philosophy and psychology of art. For instance, the representatives of German classical philosophy (Kant, Hegel) the emergence of the new and unique in art associated with the realization of

\footnotetext{
${ }^{17}$ Apresyan, R.G., Guseynova, A.A. (2001). Etika. Entsiklopedicheskiy slovar’. Moscow.
} 
talent and display of genius. In the XX century a new integrative study of creative thinking, the methodology of acquiring the new in different fields of cognition - eristic - was formed. Depending on the line of research, scientific, legal, engineering, pedagogical and other eristic are highlighted.

The importance of innovative forms and contents is an essential feature of the western type of culture, whose homeland was the ancient culture. The guiding principle of this tradition to new forms and content, as well as to their struggle with the outdated, is rooted in the image of Prometheus, who defies the gods, and then goes through all epochs to make himself known. Ancient and medieval culture is dominated by tradition, despite the emergence of new cultural forms and content, and the emergence of Christianity is a vivid example. However, everything new that arises in these historical and cultural types originates for the purpose of archiving the existing or creating something that will be its preservation and reproduction. Since the Renaissance, innovation has been gaining ground. The need for the new, the change of the existing, the expansion of rational logical and theoretical discourse are becoming the dominant values of humanity. The classical tradition of philosophizing, which had its direct transcription in culture and art, sought to balance the dualism of tradition and innovation, focusing on one pole in this pair of concepts, then on the other (for example, for romanticism, as an artistic style, priority was given to innovation which had its energetic potential. For classicism tradition played a dominant role; everything beyond its boundaries must have been overcome. In the conflict of feeling and obligation, the judgment of the latter prevailed). The postclassical artistic paradigm formed the attitude to the tradition which was the most radical in Western culture. It was proclaimed a brake of development, an obstacle to the universal renewal of art. Innovation, as the antithesis of a tradition that does not allow the new to come true, has its fullest manifestation in postulates and stylistic means of avant-garde art. However, the tradition was implicitly represented there as well. Non-classical philosophy and art continued to develop the inheritance of classical culture, they took into account all the taboos of their predecessors, everything that was outside the sphere of rational before.

Efforts to change the world for the better, to find more sophisticated forms, new recipes for solving new problems aim to realize the new; a challenge to people, the world and God are in the nature of innovation. The path of humanity through the mazes of its history is the path of innovation progress. The new is slowly reclaiming more and more planes for its own realization, starting from value-neutral contexts, from improvements of means of labor and logistical innovations, at the same time reaching awareness of the possibility and necessity of changes in the social, political, moral, ideological 
environment. The nature of innovation in industrial society was pointed out, in particular, by D. Bell, according to whom the classical culture of the era of industrial society has a dualistic character, it is innovative in the production sphere and traditional in the non-productive sphere. A post-industrial society, whose structures are developing strongly nowadays, overcomes this dualism, blurs the borders proclaimed by it $^{18}$.

\section{A synchronous section of innovation culture: the unity of natural science and humanitarian knowledge} as a characteristic of innovation culture

Innovations penetrate all spheres of society and human life. In the second half of the XX century innovations in their transformed form have become not only the dominant trend of time, they have also become a special profession (so-called venture firms, specializing in the discovery of new technologies and new markets, emerged; stakeholders, people who influence activities or decisions, are becoming more popular).

The technical capabilities gained by modern mankind increasingly call into question the self-sufficiency of any innovations. Change for the sake of change, for the sake of the new becomes more and more problematic, demonstrating the obvious absurdity of this guideline.

The global problems of humanity have clearly demonstrated the imperfection of only a technically and technologically oriented civilization. The self-sufficiency of the new is increasingly questioned. The unchanged is increasingly cultivated (from natural foods to natural artifacts as perfect art forms); the cult of archaicism, the mythologization of modern culture, the creation of its own mythology (which does not change and is replicated), are vivid examples.

We can make a statement that the striving for self-sufficiency of the new is long gone. Nowadays researchers warn against a cult of novelty existing in society, which leads to pseudo-innovations or innovative pathology, when the new is not better but sometimes worse than something that already exist; and it can be seen as evidence of the dominant role that innovations play today. Paradoxically, in modern technical and technological world, innovations are "dying" to be reborn in a more sophisticated form. Let's recall that the term "innovation" is derived from Latin "innovatio" - "update", "recovery", "change", it is also etymologically associated with the English word "innovation" - novelty. Innovation is the denial of the new: everything that is created is not radically different, distinct from the tradition. Innovation is a modern response to the harmony of tradition and novelty, intuitively sought

${ }^{18}$ Bell, D. (1996). Prykhid postindustrialjnogho suspiljstva. Kyiv: Lybidj. 
by the classical paradigm of culture, which is so nostalgic for modernity. In our opinion, the era of innovations removes the antagonism that has taken place in the thinking of previous eras and offers a new model of coexistence of tradition and novelty through innovation.

In the modernity we can ascertain the origin of that harmonious combination of science and poetry (Schelling), Apollonian and Dionysian (Nietzsche), rational and non-rational, that was the subject of works of different philosophers during the history. The impetus to find the mechanisms for such a combination is an urgent need to overcome an ideological crisis that has engulfed all of humanity and is constantly reminding itself because of the need and impossibility to solve the global problems.

An innovation culture is a culture aimed at finding, creating and introducing the new, while preserving the existing for the sake of the future. It seeks to find such the "new" that will clearly benefit from its use and implementation, to this end it integrates the old and the new, tradition and innovation, and seeks new ways of atypical combinations. The ideological and theoretical basis of the innovation culture, outlined in the synergetic postulates, convinces of the possibility and the productivity of such an approach.

Innovation combines not only tradition and novelty, but also technical and aesthetic, scientific and artistic principles, it emerges as a dialectical unity of natural science and humanitarian knowledge.

The juxtaposition of humanitarian and natural knowledge, despite some differences in the subject of study (the sphere of the spiritual life of human and the world is the object of knowledge of the humanitarian, and the sphere of the natural is studied by the naturalist), is, rather, evidence of differences in their search for methods of constructing their theoretical basis, the main purpose - the establishment of truth and the construction of a coherent theoretical framework - is common.

Modern science, traditionally differentiated into the natural sciences and humanities, is the heir to a worldview paradigm that traces its origins back to the Antiquity, its key tenets about the need to study the world through mind were formed in the Renaissance and received their theorizing in the modern history. This differentiation (natural and humanitarian knowledge) was formed as a result of elaboration of theoretical postulates of the modern history, which continued the idea of the Renaissance humanists about the necessity of studying the world, and secularization of scientific knowledge was continued and theoretically proved. Before the philosophy of the modern history, the differences of "natural sciences" and "spiritual sciences" were mentioned only in order to substantiate the integrity formed by the relationship between them (cosmogonic integrity of the universe was proved 
by ancient thinkers, medieval mystics sought for ways of material realization of spiritual truths, romantics dreamed about the integrity of the world and the knowledge that humanity had collected created by science and art).

The juxtaposition of the "natural sciences" and the "spiritual sciences" was initiated by a non-classical philosophical tradition, which made it the subject of its study. This juxtaposition (the "natural sciences" and the "spirit sciences") was carried out in the works of representatives of the Baden School of Neo-Kantianism by W. Windelband and H. Rickert. The purpose was to substantiate the epistemological originality and status of social and humanitarian disciplines which differ from natural science. In the scientific discourse of the XX century the juxtaposition was subsequently changed to a distinction, often antagonistic. Such a distinction casts doubt on both modern science and the practice of the everyday life of a person of the XXI century.

In the middle of $\mathrm{XX}$ century the issue of comparing the humanities and natural sciences has received a new vector of discussion because of the publication of the book by American researcher C. P. Snow "The Two Cultures", which has spread the ideas he presented on May 7, 1959 at a lecture at Cambridge University. The researcher notes the distinction of social-humanitarian and natural knowledge and their spheres of activity in the modern world, warns against the dangers of such distinction, and points to the integration between them as the only productive path of development. "The clashing point of two subjects, two disciplines, two cultures - of two galaxies, so far as that goes - ought to produce creative chances. In the history of mental activity that has been where some of the break-throughs came. The chances are there now"19.

Opinions about the harmfulness of the distinction of natural science and humanitarian knowledge were also expressed by the French philosopher O. Koyré. Although science deals with quantity as a category that captures the diversity of the world, and culture (as the embodiment of humanitarian knowledge) with quality, science and culture are closely intertwined. Scientific thought has always arisen in an environment of intellectuals of different times, who were concerned not only with theoretical searches in a particular field, but also with the ideological problems that were the subject of the widest debate, and the great scientific revolutions in the history of mankind have always resulted in a change in philosophical concepts ${ }^{20}$.

The philosopher's ideas about the impact of humanitarian studies on the development of the natural sciences are confirmed by many examples.

\footnotetext{
${ }^{19}$ Snow, C.P. (1998). The Two Cultures. New York: Cambridge University Press, p. 16

${ }^{20}$ Koyre, A. (1985). Ocherki istorii filosofskoy mysli. Moscow: Progress.
} 
In particular, the physical ideas of W. Heisenberg were influenced by the philosophy of Plato, N. Bohr's concept of complementarity was the result of reflections on the philosophical ideas of S. Kierkegaard, E. Schrödinger's quantum mechanics was formed under the influence of ancient Indian philosophy, A. Einstein pointed out that F. Dostoevsky gave him more than physicist Gauss. Moreover, a number of scientific ideas were firstly formulated in philosophical works. For instance, the ancient Greek philosopher Thales of Miletus wrote about water as the primary and the first element of the world, which contains "everything" in itself; another thinker of the time, Democritus, was first who proposed the concept of an atom and developed it, noting the relationship between atom mass and velocity, later justified by I. Newton. Or another example. The speed of light became known in the West only in the XVII century. However, it is referred to in one of the Vedas, the religious and philosophical text of ancient India. As noted by Manoj Kumar Bharti in his book "Understanding Indian Philosophy Through Modern Science", the Asanaveda text indicates the speed of light calculated in units of measurement that existed in the culture of ancient India. This figure is the same as the speed of light calculated by scientists and recorded in modern units of measurement. The inaccuracies that occur between these figures are very minor ${ }^{21}$.

Both C. P. Snow, O. Koyré, and other scholars have pointed out that scientific ideas are always the result of intellectual communication, whose subject of discussion is primarily a matter of worldview. So cultural and philosophical studios have a strong creative potential for scholars of natural sciences.

However, this influence is interrelated. A vivid example is the story of the painting "Galatea of the Spheres" (1952) by Salvador Dali, one of the main representatives of twentieth-century surrealism, which is stored in the collection of the Dali's Theatre-Museum in Figueres. The picture is the result of Dali's fascination with the theory of radioactive decay, the physics of the atomic nuclei, and of elementary particles, which was the subject of discussions by intellectuals of the time. The theory of radioactive decay is based on the assumption that radioactive decay is a spontaneous process, the speed of which is not affected by any external changes in temperature, pressure, the presence of electric and magnetic fields, etc. Radioactive decay is a property of the atomic nuclei, and it depends only on its internal state. The artist's wife Gala's face is made up of individual fragments, which are spheres of different sizes and colors that create a three-dimensional image

${ }^{21}$ Manoj, K. Bharti (2018). Understanding Indian Philosophy through Modern Science. Brand Books. 
with its own axis of symmetry. Another widely publicized example is the office building in Zimbabwe, Harare, which is designed by Mick Pierce ${ }^{22}$. Born in Zimbabwe, he studied architecture in London and, besides admiring the architecture, had a keen interest in exploring the world of natural ecosystems. M. Pierce laid the principle of construction of the anthill as the basis of his architectural project. The office building was opened in Zimbabwe in 1986. It is interesting that a temperature of $+22 /+24{ }^{\circ} \mathrm{C}$ is maintained in the building without the use of air conditioning. The example cases are not alone.

\section{CONCLUSIONS}

The syncretic and synthetic nature of innovation culture makes it a culture of creativity. Innovation culture requires the development of creativity, associative and integrative thinking not only from individuals but also from the general public.

Creativity is the activity of a person, where the creation of something qualitatively new is the result. Creativity has a non-linear synergistic nature, emergent structure and bifurcation-ambivalent structure. In creativity, the flexibility of the mind and the productivity of the imagination, the divergence (the ability to disperse in different directions) and the alternativeness (the ability to overcome stereotypes and clichés, to search for new options), the ability to empathy and altruism play an important role. Both inspiration and insight, and systematic and persistent work play an important role in the creative process. All stages of the creative process are the syncretic unity of the conscious and the unconscious. Creativity is described as the unity of the three S: Sensivity, Synergy, Serendipity.

Innovation culture is a culture of creative combination of tradition and novelty, humanitarian and natural knowledge, rational and non-rational principles in order to create something new that can help modern humanity not only solve urgent problems of life but also solve urgent problems of survival. The theoretical basis of innovation culture is the modern non-linear picture of the world, which is explained by synergetics as a science of the formation and development of open systems.

The picture of the world is a cognitive basis of the worldview, a set of ideas about the structure of reality, ways of its functioning and changes. An important component of the picture of the world is the scientific picture of the world. By the term "scientific picture of the world" we mean a holistic

\footnotetext{
${ }^{22}$ Jokhanson, F. (2011). Efekt Medychi: innovacijni vidkryttja na peretyni idej, koncepcij ta kuljtur. Lviv: Ukrajinsjkyj Katolycjkyj Universytet, pp. 19-20. 
system of ideas about the world, its general properties and patterns, which arise as a result of generalization and synthesis of concepts, principles of natural sciences, humanities and other sciences; it is a set of substantive content that a person possesses.

The modern, post-nonclassical picture of the world is evolutionarily synergistic and has a paradigm of formation and self-organization. Synergetics, a science that studies the general principles of the processes of self-organization that take place in systems of different nature, formulates the basic ideological and methodological foundations of the post-classical picture of the world. The founder of synergetics is the German physicist H. Hacken ${ }^{23}$. The post-nonclassical picture of the world is focused on integrity and development as the most important characteristics of being. Since the emergence of synergetics as a science, they have been talking about synergistic principles in the natural sciences, but nowadays researchers demonstrate the productivity of applying these ideas to the humanities in order to study better the subject of knowledge of these sciences, which is changing dynamically.

Features of the modern scientific picture of the world are recognition of the irreversibility of evolutionary processes that have a nonlinear character; substantiation of the bifurcation nature of evolution; the perception of the world as a complex system that can change structurally (due to the restructuring of its structure) and systematically (by moving to another level); understanding the world as a whole with a fractal structure and subordinated to the principle of the emergence (when the whole is greater than the sum of its parts); the perception of chaos is as real and constructive as orderliness; understanding the future as a spectrum of alternative scenarios, where each is probable.

The basis of synergetics is the understanding of the world as the non-linear whole.

Synergetics builds an evolutionary synergistic picture of the world, fundamentally different from the classical Kantian and non-classical quantumrelativistic ones. According to it, the world exists as a set of different nonlinear processes capable of occurring spontaneously. The picture of the world is integrated and pluralistic.

Innovation culture emerges as a consequence of embodying the principles of the evolutionary synergistic picture of the world, as a response to the demand for the embodiment of its ideological principles in sociocultural practices. A powerful impetus for the development of an innovation culture is

${ }^{23}$ Haken, H. (2012). Advanced Synergetics: Instability Hierarchies of Self-Organizing Systems and Devices. New York: Springer Science \& Business Media. 
the urgency of solving global problems of humanity. These problems arise as a result of embodying the philosophical principles of the classical and partly non-classical picture of the world. It is not possible to solve these problems on the basis that produces them. The post-classical picture of the world forms such a powerful potential.

An innovation culture is a way to solve global problems of modernity, it is a way for humanity to the joint creation of its own future.

\section{SUMMARY}

The article deals with the term "innovation culture" which now is increasingly used. Two approaches to its interpretation are dominant: as an integral characteristic of the person (or other entity: organization, corporation, institution, etc.) and as characteristics and forms of modern culture. Within both contexts, the essential features of innovation culture are traced: the dialectical unity of tradition and innovation (vertical section) and the unity of humanitarian and natural science knowledge (and forms of culture) (horizontal section). Innovation culture has a fundamental integrity as its cornerstone. It is a culture of creativity, it requires the development of creativity, associative and integrative. The ideological principles of innovation culture are shaped by a modern, non-linear picture of the world. Synergetics provides the methodological basis for understanding the innovation culture.

\section{REFERENCES}

1. Apresyan, R.G., Guseynova, A.A. (2001). Etika. Entsiklopedicheskiy slovar'. Moscow.

2. Bell, D. (1996). Prykhid postindustrialjnogho suspiljstva. Kyiv: Lybidj.

3. Differences in Innovation Culture Across Europe. TRANSFORM. URL: http://transform-eu.org/publications/documents/Differences\%20in\%20 Innovation\%20Culture.pdf.

4. Drucker, P. (2001). Management Challenges for the 21st Century. New York: Harper Business.

5. Floryda, R. (2018). Homo creativus. Jak novyj klas zavojovuje svit. Kyiv: Nash format.

6. Gegel', G.V.F. (1993-1994). Lektsii po istorii filosofii. Saint Petersburg: Nauka.

7. Green Paper on Innovation. European Union. URL: http://europa.eu/ documents/comm/green_papers/pdf/com95_688_en.pdf.

8. Haken, H. (2012). Advanced Synergetics: Instability Hierarchies of Self-Organizing Systems and Devices. New York: Springer Science \& Business Media.

9. Jokhanson, F. (2011). Efekt Medychi: innovacijni vidkryttja na peretyni idej, koncepcij ta kuljtur. Lviv: Ukrajinsjkyj Katolycjkyj Universytet. 
10. Koyre, A. (1985). Ocherki istorii filosofskoy mysli. Moscow: Progress.

11. Kyrylenko, K., Kunderevych, O., Bojko, L. (2018). Filosofija kuljtury: slovnyk. Kyiv: TOV “Aghentstvo Ukrajina”.

12. Le Goff, Zh. (1992). Tsivilizatsiya srednevekovogo Zapada. URL: https://www.gumer.info/bibliotek_Buks/ History/Goff/index.php.

13. Manoj, K. Bharti (2018). Understanding Indian Philosophy through Modern Science. Brand Books.

14. Robinson, K. (2017). Osvita proty talantu. Syla tvorchosti. Lviv: Litopys.

15. Rodzhers Everett, M. (2009). Dyfuzija innovacij. Kyiv: KyjevoMoghyljansjka Akademija.

16. Levit, S.Ya. (ed.) (1998). Kul'turologiya. XX vek. Entsiklopediya: v 2 t. Saint Petersburg: Universitetskaya kniga; OOO "Aleteyya". URL: http://yanko.lib.ru/books/cultur/culturology20century2volumes1998sl.htm\#_T oc299572017/.

17. Snow, C.P. (1998). The Two Cultures. New York: Cambridge University Press.

18. The First Action Plan for Innovation in Europe - Innovation for growth and employment. Publications Office of the European Union. URL: https://op.europa.eu/en/publication-detail/-/publication/c1944d2d-b791-4e11bc42-75c5b6f8ff35/language-en.

19. Transformation of Regional Societies Through ICTs: State(s) of the Art(s). TRANSFORM. URL: http://www.transform-eu.org/publications/ documents/d1.1_website.pdf.

Information about the author: Kateryna Kyrylenko,

Doctor of Pedagogical Sciences, Associate Professor, Head of the Philosophy and Pedagogy Department, Kyiv National University of Culture and Arts, 36, Y. Konovalets str., Kyiv, 01133, Ukraine http://orcid.org/0000-0002-3303-3947 


\section{IDENTITY AND SYMBOLS IN THE CULTURAL SPACE OF THE HUMAN BEING}

\section{Volodymyr Pylypiv}

\section{INTRODUCTION}

The individual and society's knowledge and awareness of the history of world culture significantly affect the interpretation of the world, thus contributing to the emergence of various options for social action and social relations. Such a conglomeration is a social repertoire, or vision of a person's cultural instruments ${ }^{1}$. Therefore, people develop their own life strategies.

Powerful preparation for social interaction and the availability of several strategies increase a person's confidence and ability to collective action and to social justice. Social justice is a concept that defines honest and fair relationship between person and society. It is measured by the explicit and latent conditions for the distribution of wealth, opportunities and social privileges. Social justice includes our deepest beliefs about the world and the life we want for ourselves and others, formed by politics, religion, ethnicity and a sense of identity ${ }^{2}$.

Meeting with different cultures can confirm existing beliefs, cause misunderstandings, anxiety, or even aggression, or broaden life horizons. Certain cultural models may reflect conflict situations and, at the same time, offer possible solutions ${ }^{3}$.

The new ideas perception, the world's new interpretation formation, the awareness of the options' diversity for social actions and relationships contribute to a deeper awareness of one's own cultural identity, which involves a sense of self-identification to a particular culture, the adoption of certain cultural norms, patterns of behaviour, value orientations and the like.

\section{Symbols are an integral part of the human world}

We live in a world of complex symbolism, with deep cultural roots symbols being modified, edited and compared to each other thus creating the

${ }^{1}$ Swidler, A. (1998). Culture and Social Action. In Ph. Smith (Ed.). The New American Cultural Sociology. Cambridge, U.K.: Cambridge University Press (pp. 17-187).

2 Salata, G. (2019). Bibliotekoznavstvo, informatsiini nauky ta sotsialna spravedlyvist. Ukrainian Journal on Library and Information Science, 3, 10-18. DOI: http://dx.doi.org/ 10.31866/2616-7654.3.2019.169662.

${ }^{3}$ Danylova, T. (2013). Overcoming the Cultural Differences: Parable as a Means of Intercultural Dialogue. Anthropological Measurements of Philosophical Research, 3, 42-51. 
new ones. Graphic designers often interpret cultural symbols with graphic identities.

The symbolic languages of the worlds of technology, law, games, and sports can transform a symbolic meaning into a brand due to the graphic identity built on the symbol of one of these subcultures. Social institutions, economics and culture may be unfair as such. In trying to achieve social justice, it is necessary to remember the importance of deep-seated social and cultural factors, as well as to understand how they shape the life prospects of individuals and communities. An indispensable component is the care of individual members of the community, respect for their inner world ${ }^{4}$.

Our world is saturated with symbols that are everywhere: on flags fluttering in the air, cars, tattoos on the body. Even memes turn into a symbol. As a rule, symbols are not noticed until they are used consciously or receive a negative connotation. In a significantly image-oriented culture, understanding of symbols and symbolism in general can help us to understand the nuances of our visual world.

Symbols are presented in various forms: verbal and non-verbal, written and unwritten. They are everything that conveys meaning, such as words, pictures, gestures. Clothes, homes, cars and other commodities turn into symbols identifying a certain level of social status. The symbols are culturally specific and give meaning to the world around them.

Since symbols cover both material and non-material dimensions of human life, no aspect of human experience can escape their universal reality. However, some symbols are much more common than others and are immediately identified by most people. Although they do not cause the identical feelings in everybody, hardly anyone can ignore them.

Symbols shape social reality. Often, symbols are associated with a value system of culture, which, in turn, affects people's lifestyles, goals, aspirations, and motivation to act. A separate group of symbols are cultural ones representing a certain cultural reality ${ }^{5}$. Each culture has its own set of symbols associated with different experiences and perceptions ${ }^{6}$.

These symbols contribute to a sense of belonging and cultural uniqueness. Representatives of each cultural group should correctly interpret and rethink

${ }^{4}$ Salata, G. (2019). Bibliotekoznavstvo, informatsiini nauky ta sotsialna spravedlyvist. Ukrainian Journal on Library and Information Science, 3, 10-18. DOI: http://dx.doi.org/10.31866/2616-7654.3.2019.169662.

${ }^{5}$ Danylova, T. (2018). Between the Land, Sea, and Sky: Some Words on the Art of the Minoan Civilization of Bronze Age Crete. Interdisciplinary Studies of Complex Systems, 13, 107-116. [in English].

${ }^{6}$ Danylova, T.V. (2016). The Theory of Civilizations Through the Lens of Contemporary Humanities. Anthropological Measurements of Philosophical Research, 9, 55-62. DOI: 10.15802/ ampr2016/72231. [in English]. 
their symbols over time. On this basis, it seems relevant to study a number of issues, including a thorough analysis of the phenomenon of the symbol in the multi-layered model of culture (the onion model of culture).

Cultural identity is a major value factor in the development of ethnically diverse societies. By influencing the processes of integration and disintegration, cultural identity simultaneously functions as an indicator of the internal state of the multi-ethnic community as a socio-cultural system.

The concept of cultural identity is constantly drawing the attention of scholars. It needs a deep, multifaceted study from theoretical, methodological, and ontological positions.

Its development depends on the scientific orientation of the researchers and the basic assumptions about the nature and history of cultural identity. A modern person is a representative of different cultures interacting and influencing one another at the level of countries, regions, religions, organizations, social groups, families and the like. The diversity of membership patterns across groups is likely to hinder the formation of a single culture, shared by all group members. Even one individual will "change" within the accepted culture. Cultural exchange includes three aspects, such as mental models, preferences, and artifacts. Mental models are the knowledge, beliefs, and procedures that help members of a particular group interact with the outside world. Culture has a significant impact on mental models and related systems of thought ${ }^{7}$.

Social and scientific approaches conceptualize cultural identity as a process of "social categorization" based on both individual choice and the relationship between an individual and the group / groups ${ }^{8}$.

Interpretive cultural approaches consider cultural identity as a social and cultural construct that depends not only on a person, but is dynamically created, discussed and enhanced in the process of interaction with representatives of in-groups and out-groups ${ }^{9}$.

The critical approach representatives regard cultural identity as an "ideological" construction and power structures representation ${ }^{10}$.

${ }^{7}$ Salata, G.V., Bachynsjka, N.A. (2019). Kultura i komunikatsiia: yak kultura vplyvaie na spryiniattia informatsii. Bibliotekoznavstvo. Dokumentoznavstvo. Informologhija, 3, 80-87.

${ }^{8}$ Berry, J.W. (1980). Introduction to methodology. In H.C. Triandis \& J.W. Berry (Eds.). Handbook of cross-cultural psychology, 1. Boston: Allyn and Bacon (pp. 1-28).

${ }^{9}$ Collier, M., \& Thomas, M. (1988). Identity in intercultural communication: An interpretive perspective. In Y.Y. Kim \& W.B. Gudykunst (Eds.). Theories in intercultural communication (International and Intercultural Communication Annual), 12. Newbury Park, CA: SAGE 12 (pp. 99-120).

${ }^{10}$ Shin, C.I. \& Jackson, R.L. (2003). A review of identity research in communication theory: Reconceptualizing cultural identity. In W. J. Starosta \& G.-M. Chen (Eds.). Ferment in the Intercultural Field: Axiology/Value/Praxis. Thousand Oaks, CA: SAGE (pp. 211-241). 
The history of culture in general and culture in particular, is a conditioned way of individual or collective behaviour, based on the past and projected into the future. The history of culture is cyclical. The cultural specificity of a nation is a set of historical, prehistoric factors, and the national psyche is a mysterious force hidden in national customs, oral traditions and language.

Beyond our conscious perception it is the power motivating our behaviour and triggering our impulses. The implicit, volatile and often uncertain national character is manifested in all aspects of the nation's life - both in historical achievements and in tragedies.

Cultural identity is based on the social experience of a society, it is objectified and institutionalized in a way of life been characteristic for the members of the defined community, differentiating it from another community's lifestyle and making it unique.

Artifacts are cultural manifestations in the material world that confirm the mental models and preferences of a particular cultural group's members. Artifacts are visible manifestations of culture, especially for representatives of other cultures. They are a key channel through which mental models and values are broadcast. Cultures differ significantly in their degree of influence on a particular group. The inclusiveness and power of culture are those aspects of cultural exchange that particularly affect the information space. The inclusiveness of culture implies the level of its influence on all aspects of individual behaviour. A strong culture universally manifests its core values, and common artifacts must be respected by all members of the group. Instead, a weak culture demonstrates a rather high level of differences between group members in observing the common elements ${ }^{11}$.

Such Ukrainian scientists as S. Storozhuk, Y. Hoyan ${ }^{12}$, V. Shynkaruk ${ }^{13}$, L. Shynkaruk ${ }^{14}$, G. Salata ${ }^{15}$, T. Danylova ${ }^{16}$, V. Pylypiv ${ }^{17}$ also paid attention to

${ }^{11}$ Salata, G.V., Bachynsjka, N.A. (2019). Kultura i komunikatsiia: yak kultura vplyvaie na spryiniattia informatsii. Bibliotekoznavstvo. Dokumentoznavstvo. Informologhija, 3, 80-87.

${ }^{12}$ Storozhuk, S. V., Hoyan, Y.N. (2016). Vplyv virtualnoi realnosti na samoaktualizatsiiu tyneidzheriv: antropolohichnyi vymir. Anthropological Measurements of Philosophical Research, 9, 17-28. DOI: 10.15802/ ampr2016/72119.

${ }^{13}$ Shynkaruk, V., Salata, G. \& Danylova, T. (2018). My thas the Phenomenon of Culture. Academy of Managerial Staff of Culture and Arts Herald, 4, 17-22.

${ }^{14}$ Shynkaruk, L., Salata, G. \& Danylova, T. (2018). Dialogue of Cultures: E. Hall and F. Kluckhohn. Academy of Managerial Staff of Culture and Arts Herald, 3, 128-133.

${ }^{15}$ Salata, G. \& Danylova, T. (2018). The Ecological Imperative and Human Nature: A New Perspective on Ecological Education. Interdisciplinary Studies of Complex Systems, 12, 17-24.

${ }^{16}$ Danylova, T. (2015). The Way to the Self: The Novel "Steppenwolf" Through the Lens of Jungian Process of Individuation. Anthropological Measurements of Philosophical Research, 7, 28-35.

${ }^{17}$ Pylypiv, V. (2019). Arkhetypni kulturni symvoly ta formuvannia kulturnoi identychnosti ukraintsiv Kanady: do postanovky problemy. National Academy of Managerial Staff of Culture and Arts Herald, 1, 190-194. DOI: https://doi.org/10.32461/2226-3209.1.2019.166907. 
the study of cultural identity as a necessary component of individual and collective identity. However, the concept of cultural identity requires a thorough development, a closer attention of Ukrainian researchers to this phenomenon.

Culture is a conglomeration of cognitive and evaluative beliefs / ideas about desirable reality that are detailed in values, institutions, and norms ${ }^{18}$. Culture can be interpreted as denotative, connotative and pragmatic knowledge shared by a certain group with a common history and participating in the society structuring ${ }^{19}$.

Culture is not an abstract concept - it is "embedded" in the realities of everyday life. In fact, culture cannot be separated from the social realities in which it develops, or from the people who are both its creators and creations. For a deeper understanding of culture and avoiding simplified interpretations, it is necessary to take into account the social realities, political, geographical, demographic and economic aspects of society.

The history of Ukrainian culture ... like any other, imbued with symbols that transmit its meaning from one generation to the next. Culture symbols can be of two types - external and internal, that is, visible and patterns of behaviour or results of behaviour, perceived by others. These include dances, diaspora members' gatherings, pictorial and linguistic presentations, art objects and more.

Although internal symbols are usually transmitted through external symbols, they are cognized intelligently or intuitively, not merely conceived. These include beliefs, values, feelings and ideas, for example, religious beliefs, political or social values, such as the value of democracy; legends, mythology, or a particular group history and a group self-identification sense.

Preserving ethnic identity across generations does not necessarily mean preserving all the characters contained in the culture. In fact, the ubiquity of a culture does not mean that all its symbols are equally significant or accepted by all members of the community. People selectively use cultural symbols. This is especially true of different generations living in a culturally diverse environment ${ }^{20}$.

Although many claim that we are now living in an age of text, our active use of symbolic images proves another thing. Symbols are the basis of culture.

${ }^{18}$ Kemper, D. (1993). Sociological Models in the explanation of emotion. In M. Lewis \& J.M. Havilland (Eds.). Handbook of Emotions. New York: The Guilford Press (pp. 41-51).

${ }^{19}$ Swidler, A. (2003). Talk of Love; How Culture matters. Chicago, Il: University of Chicago Press (pp. 250-285).

${ }^{20}$ Pylypiv, V. (2019). Arkhetypni kulturni symvoly ta formuvannia kulturnoi identychnosti ukraintsiv Kanady: do postanovky problemy. National Academy of Managerial Staff of Culture and Arts Herald, 1, 190-194. DOI: https://doi.org/10.32461/2226-3209.1.2019.166907. 
A symbol is an object, word, or action full of hidden meanings not rooted in the natural world, but in the world of culture. Human life and human interaction are based on cultural symbolism and manifest through it. Symbols mean different things to different people; some are from experience, others are from culture.

Symbolic representation has been inherent in humanity throughout history. Different clans and tribes had their own symbolism, with which they decorated their banners, shields and clothes. These symbols contained the meanings, people attached to certain shapes, colours, textures, and images. All this was used in the process of communicating with other clans and tribes thus identifying the designated cultural group by certain symbolic images.

A symbol is defined as anything that has a specific meaning and the meaning is recognized by a particular culture representatives ${ }^{21}$. Symbols help members of one culture to understand what other parties are doing ${ }^{22}$.

The perception, interpretation, and experience of using symbols vary across cultures. Therefore, symbols can be of special meaning for people sharing the same culture and not have a deep semantic load for members of other cultures, while not causing a negative reaction.

For example, on the first day of Chinese New Year, the Chinese tend to dress bright in colours such as red, believing that bright colours bring happiness, prosperity and good luck throughout the year. However, this custom is not mandatory for other cultural groups. Today, the cultural speech of mankind includes more and more visual forms of communication. Even the use of characters begins to change ${ }^{23}$.

Interpreting the specific character of the symbol, A. Losev highlighted its natural decomposition into many reincarnations, which is to be the most original feature of the symbol. According to the philosopher, the symbol of a thing, though being its reflection, actually contains much more than the thing itself, since we perceive every thing as it is at the moment. Instead, the hidden symbol contains all possible manifestations of a thing. It is this extraordinary generalization and ideological richness that make it the basis of culture ${ }^{24}$.

Thus, the symbol acts as the principle of constructing a thing or phenomenon, providing them with a deeper meaning. A symbol generates a thing or phenomenon, shaping their internal pattern. This generation is only a penetration into the deep and natural basis of the very things presented in the

\footnotetext{
${ }^{21}$ Macionis, J. (2005). Sociology. Pearson Prentice Hall.

${ }^{22}$ Peoples, J. \& Bailey, G. (2017). Humanity: An Introduction to Cultural Anthropology. Cengage Learning.

Unger, J. (2018). Symbols and Symbolisms in Culture. Papyrus. URL: http://papyrus.greenville.edu/ 2018/02/symbols-and-symbolisms-in-culture.

${ }^{24}$ Losev, A.F. (1995). Problema symvolu ta realistychnoho mystetstva. Moscow: Iskusstvo.
} 
sensual reflection, only very vague, uncertain and chaotic ${ }^{25}$. The symbol combines single things into certain integrity, fixing it in cultural code and transmitting it to subsequent generations.

Symbols give rise to a deep sense of existence, elevates man above the "world of consumption". Symbols cannot be interpreted within the framework of formal logic because they appeal to instincts, affects and emotions; they provide opportunities to comprehend life, because life itself gives rise to emotions and symbolic ideas.

In the process of comprehending a symbol, we should take into account not only the symbol itself, but also the uniqueness of the culture that generated it. It is important for anthropologists to consider their own cultural background while studying symbolism in a different culture. This is because many symbols, although similar in appearance, can have different meanings.

These symbols need to be interpreted through the prism of the particular culture to which they refer; otherwise they may lose their unique meaning. One example of a misinterpreted cultural symbol is the swastika symbol, which is a long-standing solar symbol, spread from India to America. Because it looks almost identical to the Nazi swastika, it provokes a negative reaction in many people.

Cultural symbols are commonly used to express "eternal truths". They go a long way in transforming and acquiring conscious characteristics, gradually obtaining the qualities of collective images adopted by a particular culture. Symbols that are part of human culture retain a significant charge of their original energy, causing some people to have a strong emotional response.

This original energy is fully manifested in natural symbols, arising from the subconscious content of the psyche and representing innumerable variations of the basic archetypal images. In many cases, they can be traced back to their original roots, that is, ideas and images found in ancient sources that came from primitive societies ${ }^{26}$.

Language is the most commonly used form of symbolism. There are 6,912 living languages known, with their diversity been caused by some isolation. Most languages have their own "symbols" to indicate each letter, word or phrase. Using a language is adaptive: for example, there are two language groups in contact with each other it causes a need of finding ways of communication.

They create a language that has a great deal of flexibility in using language symbols (sound models) or a hybrid set of symbols for transmitting messages. This contact language - the pidgin - eventually gives way to the creole

\footnotetext{
${ }^{25}$ Losev, A.F. (1995). Problema symvolu ta realistychnoho mystetstva. Moscow: Iskusstvo, p. 47.

${ }^{26}$ Yunh, C.G. (1991). Arkhetip i simvol. Moscow: Renessans, p. 84.
} 
language with a more formal set of symbols (words), grammatical rules for organizing them, as well as their own native speakers transmitting language from generation to generation.

Language is the key to the world of culture and a system of symbols that allows people to communicate with one another. The sense-creative function of symbols forms a single cultural space of a particular group, promotes cultural identification, produces a common meaning, provides guidelines for individual existence, and transmits cultural values into the future. The symbols' usage is adaptive. This means that people can learn to associate new characters with an established concept or a new concept with a familiar symbol.

\section{Basic approaches to understanding the phenomenon of culture}

There are different approaches to understanding the phenomenon of culture. The essentialist point of view is based on the idea that culture is conditional and static, it has fixed characteristics, and differences between representatives of one culture are considered secondary.

In a globalized world where people often migrate, travel both physically and virtually, live in constant interaction with other cultures, this approach is considered to be irrelevant. Moreover, such a reductionist view of culture restricts human understanding only to the theories and methodologies not corresponding the realities of the XXIst century.

But the constructivist approach defines culture as a multi-faceted dynamic phenomenon being in continuous evolution. From the constructivism's point of view, culture is defined through interaction between people; being fluid, it constantly evolves and adapts to new realities.

Thus, culture develops and changes over many years; it is affected by the interaction of its members with members of other cultures and with their environment, as well as cultural and economic exchange and globalization.

This type of discourse interprets culture as a process that is multifaceted and diverse in its values, beliefs, practices, and traditions, some of which may be completely new. Thus, from this point of view, culture is negotiable, giving opportunities for personal choice, social justice, and a dynamic process whereby the arrangements and boundaries of groups or communities are revised in accordance with current needs ${ }^{27}$.

Combating social exclusion, implementing the principle of social justice is one of the important factors in the history of postmodern world culture. Social justice is a concept that defines a fair and honest relationship between man and society. It is measured by the explicit and latent conditions for the

27 Intercultural Learning: theories, contexts, realities. (2009). URL: https:// pjp-eu.coe.int/documents/1017981/10762748/Ch2.pdf/0b364432-7efb-6a45-a4bc-50de19787213. 
distribution of wealth, opportunities and social privileges. Social justice includes our deepest convictions, shaped by cultural identity, politics, religion, ethnicity, and a sense of identity ${ }^{28}$.

Our perception of culture influences the interpretation of cultural reality, our interaction with others, and the way we understand our identity and that of others. Of course, culture is not the answer to every question, but it is an important aspect that shapes our worldview and our interpretations, along with other aspects such as living conditions, gender, sexual orientation, social and economic status, etc.

In the context of culture, like many other dimensions, identity is constantly being built, and the process of the role's acceptance and fulfilment, mediated by external (social, political) and internal (psychological, emotional) aspects, lasts throughout life ${ }^{29}$.

A fluid cultural identity can be understood as the unification of two identities - individual and group - into one. Thus, cultural identity is always in the process, it is never a complete fact ${ }^{30}$.

If we consider our identity as static, ascriptive, we are inclined or forced to conform to a certain system of expectations regarding cultural norms, gender roles, religious beliefs, and the like. Understanding our identity and the identity of other people as a dynamic process allows us to constantly change our identity according to our needs, aspirations, expectations, and not according to what the world expects.

An important aspect is that within the outlined paradigm, we allow other people to build their own identities, refraining from stigmatization, social stigma, perception through the prism of stereotypes.

Thus, identity can be defined as belonging to one group and differentiating from others. Depending on the context in which we are, we are constantly reevaluating our identity. For example, a single woman in a male group may have a stronger understanding of gender identity than in a mixed gender group. Therefore, modern researchers turn to the concept of "multiple identities" ${ }^{\prime 31}$.

${ }^{28}$ Salata, G. (2019). Bibliotekoznavstvo, informatsiini nauky ta sotsialna spravedlyvist. Ukrainian Journal on Library and Information Science, 3, 10-18. DOI: http://dx.doi.org/ 10.31866/2616-7654.3.2019.169662.

${ }^{29}$ Ohana, Y. \& Otten, H. (2012). A new intercultural learning concept for the European youth sector? In Ohana, Y., Otten, H. (Eds.). Where do you stand? Intercultural learning and political education in contemporary Europe. Berlin, Germany: VS VS Verlag für Sozialwiessenschaften (pp. 183-240).

${ }^{30}$ Kim, Y. (2009). The Identity Factor in Intercultural Competence. In D. K. Deardorff (Ed.). The Sage Handbook of Intercultural Competence. Thousand Oaks, CA: Sage (pp. 53-65).

31 Danylova, T. (2012). Problema liudskoi identychnosti u postmodernii kartyni svitu. Anthropological Measurements of Philosophical Research, 3, 16-22. 
Although this concept is mainly used to analyse people who have combined different cultural traditions, it can be extended to any person in a changing social context, the "search for the Self" is largely a reaction to the science's confidence in its own efforts to explain the outside world and determine the place of man in this world.

In fact, this is due to the recognition that the reality we perceive is not a "perse" reality, but rather constructed by the mind itself. That is why the postmodern era is very sceptical of the explanations that claim absolute truth. Instead, it focuses on the relativity of truth for each individual.

In the postmodern sense, everything is an interpretation - we create our own reality by interpreting the world around us. Reality arises through our interpretation of what the world means to us personally. Preferring concrete experience over abstract principles, postmodernism argues that the results of one's own experience are relative rather than definitive and universal, and tries to offer a new understanding of man within the discourse ${ }^{32}$.

Identity becomes fluid; it is formed and constantly transformed in ways of representation in the cultural systems that surround us. As S. Hall noted, "within us are contradictory identities, pulling in different directions, so that our identifications are continually being shifted about ${ }^{33}$."

A person's identity is defined both through self-identification (as we identify ourselves) and through hetero-identification (as others identify us). At the individual level, identity is closely related to the need to interact with others, with society as a whole and with the recognition of one's own autonomy. More often, the identity that a person "assigns" differs from the identity that others "attribute" to it.

Even through the prism of the dynamic, constructivist point of view of the postmodern era people often assume that there is only one identity. This type of worldview generates cognitive dissonance, which is extremely dangerous, especially in a globalizing world and growing cultural contacts.

Individuals strive to maintain a positive self-identity and feel safe within their identity. To achieve this, various strategies are used. One is to emphasize the differences between in-groups and out-groups, which can create artificial categorization that emphasizes differences and reduces similarity. This often leads to competition or confrontation, which in some cases causes acts of violence and discrimination.

${ }^{32}$ Danylova, T.V. (2017). Searching for the True Self: The Way of Nondual Wisdom. Anthropological Measurements of Philosophical Research, 12, 7-15. DOI: 10.15802/ ampr.v0i12.119069.

${ }^{33}$ Hall, S. (1992). The Question of Cultural Identity. In S. Hall, D. Held and T. McGrew (Eds.). Modernity and Its Futures. Milton Keynes. Cambridge: Open University Press (pp. 27-316). 
To avoid this dissonance and related problems, to create a narrative congruent, any individual needs to integrate various aspects of his identity in order to feel himself as a unique and full-fledged person ${ }^{34}$. Published by the Council of Europe, the European Manifesto for Multiple Cultural at certain times or at different stages of their lives, people may have different cultural affiliations: "Multiple cultural affiliation is one way of recognising the place of plurality in the face of globalism.

Today's world is fragmented and pluralist, and modern human beings live in different groups, on different levels, and with affiliations of different degrees of intensity, making every social group heterogeneous. Today's European may be conceived in Venice, spend his or her teenage years in Paris, study in Coimbra, get married in Berlin and divorce in London. Where will he or she be buried? Cultural reference systems, that were once fixed and inviolable are now inevitably bound to change in far-reaching ways ${ }^{35}$ ".

Typically, individuals are subjectively identified with more than one social group. In addition, people often use their personal characteristics and interpersonal relationships and social roles as additional components of their own identification. These multiple identifications with social groups, characteristics, relationships and roles help people navigate the world.

For a successful intercultural dialogue, it is necessary to find a balance between accepting one's own identity, recognizing the cultural characteristics of one's group, and tolerant attitudes toward representatives of cultural outgroups.

"...Multiple cultural affiliation is becoming the central pillar of an emerging European citizenship. It makes it possible both to conceive and to experience the complex, differentiated development of cultural identity in mature democratic societies. It firstly recognises communities which bring with them different references in terms of identity, and secondly allows each individual to have a number of specific identities expressed through belonging to various cultures... multiple belonging is perceived as the possibility for everyone, either individually or in a group, to feel simultaneous or successive affiliation with a set of values or cultural references shared by several groups or communities..."36.

${ }^{34}$ Danylova, T. (2015). The Way to the Self: The Novel "Steppenwolf" Through the Lens of Jungian Process of Individuation. Anthropological Measurements of Philosophical Research, 7, $28-35$.

${ }^{35}$ European Manifesto for Multiple Cultural Affiliation. (2007). URL: https://rm.coe.int/ 16806abde8.

${ }^{36} \mathrm{Ibid}$. 


\section{CONCLUSIONS}

The scientific novelty of the work is to justify the feasibility of using the concept of multiple cultural identity in the context of globalization processes, which requires the development of a new paradigm of thinking. In modern conditions, the imperative of social and cultural interaction becomes one's own free choice of cultural affiliation, which encourages the individual to comprehend interpersonal and intergroup interactions from the position of tolerance and makes him or her open to understanding the other identities carriers.

The constructivist approach to understanding the phenomenon of culture, which has become dominant in the postmodern world, has fostered a new interpretation of cultural identity, which is understood as a dynamic process of combining individual and group identities and is not completely finalised.

The symbol is one of the most meaningful concepts in culture. Since it represents the deepest level of culture, its meaning cannot be deciphered in a directly, rationally; on the contrary, it must be experienced and felt "emotionally", gradually deciphering the whole multitude of all its meanings. Symbols carry a deep cultural and semantic load, traced back to the ancient times and reflecting archaic thinking.

Symbols act as a peculiar language and try to answer the most difficult questions of being. They direct thought beyond the individual horizon and acquire a new, unexpected sound, depending on the recipient's understanding. The symbol as a cultural memory accumulator permeates through all cultures, "translating" archetypes into the language of culture, for its interpretation it is necessary to move along the cultural "vertical", trying to understand its primary meanings.

Multiple cultural identity contributes to a person's capacity for change, the ability to cope with new challenges, the globalized world is full of. This ability to adapt is a crucial prerequisite for improving the process of intercultural communication within the new geopolitical construction of the universe. The authors see the prospects for further scientific research in the study of the cultural identification mechanisms; it has important theoretical and practical significance for the formation of a favorable cultural environment.

\section{SUMMARY}

A symbol is one of the most meaningful concepts in culture. Based on the deepest level of culture, its meaning cannot be deciphered directly, rationally; on the contrary, it must be experienced and felt "emotionally", gradually deciphering all its meanings. Symbols carry a deep cultural and semantic load, traced back to the ancient times and reflecting archaic thinking. The 
constructivist approach to culture, being dominant in the postmodern world, contributes to the emergence of a new cultural identity interpretation. It is understood as a dynamic process of combining individual and group identities, considered as fundamentally incomplete. The results of the study concluded the multiple cultural identities contributing to a person's ability to change, the ability to cope with the new challenges of the globalized world. This ability to adapt is an essential prerequisite for improving the process of intercultural communication within the framework of the new geopolitical structure of the world.

\section{REFERENCES}

1. Berry, J.W. (1980). Introduction to methodology. In H.C. Triandis \& J.W. Berry (Eds.). Handbook of cross-cultural psychology, 1. Boston: Allyn and Bacon (pp. 1-28).

2. Burke, P., \& Stets, J. (2009). Identity Theory. Oxford University Press.

3. Collier, M., \& Thomas, M. (1988). Identity in intercultural communication: An interpretive perspective. In Y.Y. Kim \& W.B. Gudykunst (Eds.). Theories in intercultural communication (International and Intercultural Communication Annual), 12. Newbury Park, CA: SAGE 12 (pp. 99-120).

4. Danylova, T. (2012). Problema liudskoi identychnosti u postmodernii kartyni svitu. Anthropological Measurements of Philosophical Research, 3, $16-22$.

5. Danylova, T. (2013). Overcoming the Cultural Differences: Parable as a Means of Intercultural Dialogue. Anthropological Measurements of Philosophical Research, 3, 42-51.

6. Danylova, T. (2015). The Way to the Self: The Novel "Steppenwolf" Through the Lens of Jungian Process of Individuation. Anthropological Measurements of Philosophical Research, 7, 28-35.

7. Danylova, T.V. (2017). Searching for the True Self: The Way of Nondual Wisdom. Anthropological Measurements of Philosophical Research, 12, 7-15. DOI: 10.15802/ampr.v0i12.119069.

8. European Manifesto for Multiple Cultural Affiliation. (2007). URL: https://rm.coe.int/16806abde8.

9. Hall, S. (1992). The Question of Cultural Identity. In S. Hall, D. Held and T. McGrew (Eds.). Modernity and Its Futures. Milton Keynes. Cambridge: Open University Press (pp. 27-316).

10. Intercultural Learning: theories, contexts, realities. (2009). URL: https://pjp-eu.coe.int/documents/1017981/10762748/Ch2.pdf/0b364432-7efb6a45-a4bc-50de19787213. 
11. Jackson, R.L. (1999). The negotiation of cultural identity: Perceptions of European Americans and African Americans. Westport, CT: Praeger.

12. Yunh, C.G. (1991). Arkhetip i simvol. Moscow: Renessans.

13. Kemper, D. (1993). Sociological Models in the explanation of emotion. In M. Lewis \& J.M. Havilland (Eds.). Handbook of Emotions. New York: The Guilford Press (pp. 41-51).

14. Kim, Y. (2009). The Identity Factor in Intercultural Competence. In D. K. Deardorff (Ed.). The Sage Handbook of Intercultural Competence. Thousand Oaks, CA: Sage (pp. 53-65).

15. Losev, A.F. (1995). Problema symvolu ta realistychnoho mystetstva. Moscow: Iskusstvo.

16. Macionis, J. (2005). Sociology. Pearson Prentice Hall.

17. Ohana, Y. \& Otten, H. (2012). A new intercultural learning concept for the European youth sector? In Ohana, Y., Otten, H. (Eds.). Where do you stand? Intercultural learning and political education in contemporary Europe. Berlin, Germany: VS VS Verlag für Sozialwiessenschaften (pp. 183-240).

18. Peoples, J. \& Bailey, G. (2017). Humanity: An Introduction to Cultural Anthropology. Cengage Learning.

19. Pylypiv, V. (2019). Arkhetypni kulturni symvoly ta formuvannia kulturnoi identychnosti ukraintsiv Kanady: do postanovky problemy. National Academy of Managerial Staff of Culture and Arts Herald, 1, 190-194. DOI: https://doi.org/10.32461/2226-3209.1.2019.166907.

20. Salata, G.V., Bachynsjka, N.A. (2019). Kultura i komunikatsiia: yak kultura vplyvaie na spryiniattia informatsii. Bibliotekoznavstvo. Dokumentoznavstvo. Informologhija, 3, 80-87.

21. Salata, G. \& Danylova, T. (2018). The Ecological Imperative and Human Nature: A New Perspective on Ecological Education. Interdisciplinary Studies of Complex Systems, 12, 17-24.

22. Salata, G. (2019). Bibliotekoznavstvo, informatsiini nauky ta sotsialna spravedlyvist. Ukrainian Journal on Library and Information Science, 3, 10-18. DOI: http://dx.doi.org/10.31866/2616-7654.3.2019.169662.

23. Shin, C.I. \& Jackson, R.L. (2003). A review of identity research in communication theory: Reconceptualizing cultural identity. In W.J. Starosta \& G.-M. Chen (Eds.). Ferment in the Intercultural Field: Axiology/Value/Praxis. Thousand Oaks, CA: SAGE (pp. 211-241).

24. Shynkaruk, L., Salata, G. \& Danylova, T. (2018). Dialogue of Cultures: E. Hall and F. Kluckhohn. Academy of Managerial Staff of Culture and Arts Herald, 3, 128-133. 
25. Shynkaruk, V., Salata, G. \& Danylova, T. (2018). My thas the Phenomenon of Culture. Academy of Managerial Staff of Culture and Arts Herald, 4, 17-22.

26. Storozhuk, S.V. \& Hoyan, I.M. (2017). Gender Equality as a Modern Phenomenon. Anthropological Measurements of Philosophical Research, 11, 71-83. DOI: 10.15802/ampr.v0i11.105481.

27. Storozhuk, S. V., Hoyan, Y.N. (2016). Vplyv virtualnoi realnosti na samoaktualizatsiiu tyneidzheriv: antropolohichnyi vymir. Anthropological Measurements of Philosophical Research, 9, 17-28. DOI: 10.15802/ ampr2016/72119.

28. Swidler, A. (1998). Culture and Social Action. In Ph. Smith (Ed.). The New American Cultural Sociology. Cambridge, U.K.: Cambridge University Press (pp. 17-187).

29. Swidler, A. (2003). Talk of Love; How Culture matters. Chicago, Il: University of Chicago Press (pp. 250-285).

30. Tajfel, H. (Ed.). (2010). Social Identity and Intergroup Relations (European Studies in Social Psychology). Cambridge, U.K.: Cambridge University Press.

31. Triandis, H.C. (1995). Individualism and Collectivism (New Directions in Social Psychology). Boulder: Westview Press.

32. Unger, J. (2018). Symbols and Symbolisms in Culture. Papyrus. URL: http://papyrus.greenville.edu/ 2018/02/symbols-and-symbolisms-in-culture.

33. Yep, G.A. (2003). Approaches to cultural identity: Personal notes from an auto-ethnographical journey. In $M$. Fong \& $R$. Chuang (Eds.). Communicating ethnic and cultural identity. Lanham, MD: Rowman \& Littlefield Publishers (pp. 69-81).

\section{Information about the author: Volodymyr Pylypiv,} Candidate of Historical Sciences, Associate Professor, Rector of Kyiv University of Culture, 20, Chyhorina str., Kyiv, 01042, Ukraine http://orcid.org/0000-0001-6548-1405 


\section{INFORMATION AND COMMUNICATION TECHNOLOGIES AS A TOOL OF SOCIO-CULTURAL TRANSFORMATION}

\section{Yuliia Trach}

\section{INTRODUCTION}

Since its inception, technology has been a unique means of transforming human society. Nowadays, technology is increasingly influencing different aspects of society, both positively and negatively, contributing to the formation of a global man-made environment. Despite the importance of engineering and technology in socio-cultural changes, today, on the one hand, we must note something late understanding the whole importance of this issue. Moreover, there is a perception that technology is outside of culture, and that people, technology, are subject to it. In fact, it is a crisis situation in relation to engineering and technology in general, which requires a comprehensive analysis of their position and role in socio-cultural processes.

On the other hand, the need for a humanitarian study of the technology phenomenon is mainly related to the contradiction of two attitudes: a) overoptimistic assessment of the achievements and prospects of modern technological development, and b) extremely critical attitude to technological progress in society (especially in the humanitarian environment). This approach to technology and technology is due to the fact that due to the peculiarities of their development, they pose a number of problems to cultural studies; in particular, it is a question of changes in culture, exploration of development trends, etc. Consideration of the technology role and technology in socio-cultural transformations is an urgent scientific, cultural, task, since "first of all, it is necessary to overcome the naturalistic, instrumental representation of technology. It should be replaced by an understanding of technology, on the one hand, as a manifestation of complex intellectual and socio-cultural processes ... on the other, as a particular habitat of a person, which imposes on him environmental archetypes, rhythms of functioning, aesthetic images, etc" .

One cannot disagree with the cultural scientist V. Rozin that "... public participation in the discussion and modern technology evaluation is one of the prerequisites for the formation of a new understanding of technology and overcoming the crisis of techno genic civilization. Efforts are equally important in other directions: breeding technology and sociality, discussing

\footnotetext{
${ }^{1}$ Rozin, V.M. (2018). Istoriya i filosofiya nauki. Moscow: "Yurayt", p. 48.
} 
new types of sociality necessary for the modern person and for the future, analyzing and minimizing the negative consequences of scientific and technological development, criticizing technocratic discourse, changing the traditional scientific and engineering picture of the world, reforms in the field of technical and humanitarian education, the creation of social institutions focused on new types of sociality, and much more. The movement in this direction is already visible, although so far it is only trends, only individual sprouts and foci of new life, which are hardly making their way against the background of the $\langle\ldots\rangle$ rapid development of the structures of techno genic civilization..."

\section{Scientific and technological progress as a factor in the development of a "techno genic" society}

Technique was used by mankind at all stages of its development, it is a natural process and "in fact, the technical basis is the man's activity and culture" ${ }^{3}$. However, today, in the era of the so-called techno genic civilization, the engineering development and technology, despite all its advantages, has become threatening to man. This is reflected in the quantitative and qualitative variety of technical means, as well as in their deep penetration into the modern man's life and society as a whole, which become largely dependent on the techno genic environment, which ultimately determines the comprehensive impact of technology on socio-cultural reality. The main features of a techno genic society are the growing role of the interaction of the sciences, the interdisciplinary study of global problems; internationalization of all human activity; techno sphere formation; increasing the socio-cultural significance of information activities; increasing the level of general and special education; formation of "mass culture"; the emergence of new human problems as a person related to the change in lifestyle and pace, the cultural system and moral values, etc.

The study of engineering and technology as the basis of techno genic civilization and as a means of sociocultural transformation is directly related to the identification of the scientific essence and technological progress, which is usually understood as a single, interdependent, progressive development of science and technology, the origins of which are derived from manufactory XVI-XVIII centuries as scientific, theoretical and technical

\footnotetext{
${ }^{2}$ Rozin, V.M. (2018). Istoriya i filosofiya nauki. Moscow: "Yurayt", p. 48.

${ }^{3}$ Rozin, V.M. (2006). Ponyatie i sovremennyie kontseptsii tehniki. Glava 5. Krizis tehnogennoy tsivilizatsii i puti vyihoda iz nego. URL: https:/gtmarket.ru/laboratory/basis/ 5612/5617.
} 
activities begin to converge ${ }^{4}$. Before that scientific and technological progress have been two, albeit indirect, but relatively separate areas of human activity ${ }^{5}$. It was during the period of manufactory production that the first scientific and technical elements of large industry began to develop, which became the basis for the development of the industrial revolution - the first stage of scientific and technological progress. The second stage of scientific and technological progress is characterized by the fact that science and technology mutually stimulate each other's development at an accelerated rate, which was made possible by machine production, which opened new, unprecedented opportunities for technological application of science ${ }^{6}$. It is the combination of science and technology that has become a decisive factor in the rapid development of technology and technology. The acceleration of technological progress has been influenced and continues to be influenced by many areas of the social sciences, such as economics and production organization, the logic of technical creativity, etc., as well as fundamentally new ideas in the fields of biology, psychology, linguistics, etc. Thus, science is constantly revolutionizing technology, which, in turn, constantly stimulates the progress of science, putting before it new requirements and tasks: "technological progress in the history of mankind has taken place to a certain extent by one and the same pattern: the continuous growth of technical improvement is not only the continuous process of social transformation, but also intensified, expanded the latter, and the specificity of socio-cultural forms of organization and transformation largely determined and technological progress" $"$.

And finally, the third stage of scientific and technological progress, which began in the mid-1950s, it is related to the scientific deployment and technological revolution, it is a qualitative leap in the productive forces development, the transformation of science into a leading factor in production, etc. Modern scientific and technological progress covers not only industry as it once was, but also education, transport, communications, medicine, agriculture, spheres of administration and everyday life, etc., which testifies to the progressive, revolutionary society's changes. Today, progress is based on accelerated mutual science development, engineering and technology, increasing technological determinism of social life and, accordingly, increasing rates of socio-cultural change. It is a "powerful social process connected with the radical transformation of the nature of productive activity

4 Volkov, G.N. (2011). Nauchno-tehnicheskiy progress. In Bolshaya sovetskaya entsiklopediya. URL: https://dic.academic.ru/contents.nsf/bse.

${ }^{5}$ Ibid.

${ }^{6}$ Ibid.

${ }^{7}$ Filosofiya nauki i tehniki. (2003) / pod red. V. V. Ilina. Moscow: Izdatel'stvo MGTU im. N.E. Baumana, p. 167. 
through the widespread displacement of living labor, the rationalization and life's intellectualization through the transformation of the knowledge power into a direct and largely decisive technological force" ${ }^{\prime 8}$. Such a scientific and technological revolution was made possible by the breakthrough technologies that not only accelerated the technological development of civilization from different directions, but also led to significant socio-cultural transformations. Among the most significant technologies, besides steam engine and internal combustion engine, electric power and aircraft construction, etc., information technologies are especially distinguished, which have become an extremely effective catalyst for, first of all, economic activity and scientific and technological, and then socio-cultural transformations, and after behind them so-called high-tech, rapidly evolving technologies: nanotechnology and biotechnology, etc. However, the main characteristic of the scientific and technological revolution is not the great scientific discoveries, not the restructuring of the entire technological mode of production, namely the receipt on the basis of scientific and technological progress of positive sociocultural transformations: it affects all society's aspects, including culture, people's psychology, the relationship of society with nature, changing consciousness and person's thinking, etc. For comparison, according to experts of the Organization for Economic Cooperation and Development, in the middle of XX century the rate of economic growth was determined by the progress of technology by $38 \%$ and by the end of the same century - by $65 \%$. It is generally accepted that this factor accounts for about $75 \%$ of labor productivity growth, more than $50 \%$ of national income growth, significantly reducing the cost of production. According to the British Labor Commission, $60 \%$ increase in the overall efficiency of US and Japanese industry is due to changes in technology?.

Such a scientific and technological revolution is also called informational, based on the revolutionary changes brought by information technologies in different spheres of society, in which there is a combination of society, bio and techno sphere into a single whole and strengthening the role of the latter in socio-natural and socio-cultural processes. It is about the formation of the techno sphere as the basis of the artificial material world. It is the technical side of the information revolution that has given impetus to a new culture development, an emerging information society culture. However, the most important result of the development of information and telecommunications technologies is the mutual proliferation process of cultures. Such processes on

${ }^{8}$ Filosofiya nauki i tehniki. (2003) / pod red. V. V. Ilina. Moscow: Izdatel'stvo MGTU im. N.E. Baumana, p. 5.

9 Khodykina, V.V. (2005). Mizhnarodna naukovo-tekhnichna integhracija Ukrajiny v konteksti strateghiji innovacijnogho rozvytku. PhD Thesis. Donecjk. 
a rather limited scale occurred in ancient times, but only in the second half, especially at the end of the nineteenth century, this process has become universal. Thanks to radio, television, cinema, the Internet and other media, the intervention of American mass culture, as well as the authoritative cultural standards of Europe and some Asian regions, into the spiritual and the world cultural space has begun. Technological means, especially the mass media, have made a decisive impact here, because information technologies are culturally diverse in general. That is, it is a culturally diverse information technology function whose essence is that they have an auto generation effect and computers and computer programs can and are being used to produce similar artifacts on an expanding scale.

The information revolution development has expanded the "field of opportunity" for development, creation, creativity and meeting more and more new needs. Human needs, human choices have become increasingly decisive determinants of scientific and technological, economic and social development. There is an "increase in the intellectual and behavioral autonomy of the individual" ${ }^{\prime 0}$. In addition, there is a weakening of connections between social groups and individuals, their social and group identity blurring, etc. The determination of group cultures is replaced by the convergence and averaging of lifestyles, behavior's motives and norms, which is expressed in the concepts of "mass person", "mass culture", "mass", which puts the person in a position of cultural and psychological loneliness. In addition, it is necessary to ascertain the degradation of culture and morality, the marginalization of large sections of the population, the change in values, ideals, modern man needs, etc.

It is worth noting that the methods of mathematical description and information measurement were used in the development of the theory in the information society that appealed to the ever-increasing amount of information, which, in fact, stated the increase of communicative acts, whereas their "efficiency", i.e the growth rate of the new knowledge could remain zero. Because of this lack of information concepts, critical theories have emerged almost simultaneously in the social and human sciences, claiming that the information revolution not only causes the knowledge formation society but, on the contrary, creates an environment in which the production of new knowledge becomes problematic. This situation prompted the theoretical and methodological need to disclose the substantive component of the technological and technological process, stipulating the use of the concept of "knowledge revolution", which just reflects the qualitative changes in the ways of producing new knowledge.

\footnotetext{
${ }^{10}$ Vasilchuk, Yu.A. (1991). Epoha NTR: masshtabyi peremen. Polis, 1-3, p. 57.
} 
As a result of the differentiation of the "information" and "knowledge" concepts to reveal the essence of the phenomena of information and knowledge revolutions and their comparisons, researchers such as G. Schiller, A. Bart and others concluded that the information revolution is not accompanied by knowledge, but rather hinders it. The reason for this is the unstructured, contradictory and fragmentary continuous information flow, which leads to the formation of an equally contradictory and fragmentary picture of the world. In addition, the modern information technology development has created a special sign reality, consisting of a continuous stream of simulacra that people do not know or understand, and which is emotionally responsive.

Considering, first and foremost, the techno and technologically determined processes and phenomena that are most closely connected with the computer technology development and scientific fields that are directly related to this kind of technology, other scientists argue about the onset of the computer revolution, noting when that it is impossible to delineate its boundaries in such a way as to separate it from other components of those processes which are characterized as the aforementioned "scientific and technical revolution", "information revolution", "knowledge revolution", "society's information" etc.

However, no matter what you call the latest revolution - whether information, knowledge, or computer, it is because of revolutionary changes that scientists have been able to build virtual models and manipulate them, to process vast arrays of primary information, to instantly obtain scientific information from any it's repositories in any country. Scientific discoveries and inventions immediately become common property. Education on the basis of information and communication technologies becomes public, continuous, distance, significantly increases the speed and efficiency of mastering new knowledge and skills of the younger generation. The ability to spread new ethical standards is facilitated. A planetary spiritual space is formed, a world foundation, which represents the values of every nation, ethnicity, every civilization, and from which anyone can absorb them according to their needs and individual taste. Thus, the information revolution has become, in fact, a new socio-cultural phenomenon that has shaped modern civilization. However, it should be borne in mind that the danger of an information revolution in the humanitarian sphere is less obvious, but more threatening in the long run, as it is at odds with the humanization of society.

When examining the engineering impact and technology on culture, one must take into account the type of sociality that has developed in recent 
centuries $^{11}$. "As long as we think that technology is the main thing, that major social problems are solved on its basis, that the well-being of humanity is directly related to the modern technologies development, we will continue to contribute to the deepening crisis of our civilization. Although technology plays an enormous role in our anthropogenic civilization, from the perspective of development perspectives it is necessary to promote the understanding that these things are different. The existing type of sociality can no longer satisfy us, the conviction that major social problems can be solved on the basis of technology, is increasingly becoming a destructive moment. Any society and culture assume technique, but are not completely defined by the latter"12. Technology should be seen as a phenomenon, as part of the culture of modernity, which significantly influences the spiritual values, socio-cultural relations of civilization, but nothing more.

Therefore, the main contradiction of modern techno genic civilization is that modern technology, on the one hand, opens unprecedented opportunities for satisfaction and even to create human needs, and on the other, creates the danger of destroying the very foundations of human existence. The French professor of economics J. Jecreo, critically reflecting on the economic foundations of modern society, clearly characterized the socio-cultural contradictions of techno genic society: "Never has our ability to produce wealth been so great, never has our inability to direct this prosperity for the benefit of all people been so evident" ${ }^{\prime 3}$. Thus, the magnitude and pace of changes in social life, which the scientific and technological revolution brings with it, with unprecedented still urgency, necessitate timely and as complete as possible prediction of the totality of their consequences in different spheres of life of modern society, including in the culture sphere.

\section{Contradictory impact of technology on modern society}

As noted above, the development of techno genic society is contradictory because, against the background of increasing scientific and technical and technological rationalization of not only production but also human life conditions, there are negative processes in these and other spheres. Initially, the scientific and technological revolution was seen as a consequence of the industrial revolution, but as the sociocultural consequences of the scientific and technological revolution became more obvious and irreversible, within the limits

${ }^{11}$ Rozin, V.M. (2018). Istoriya i filosofiya nauki. Moscow: "Yurayt", p. 48.

${ }^{12}$ Ibid.

13 Généreux, J. (2001). Manifeste pour l'économie humaine. Esprit, 7. URL: https://esprit.presse.fr/article/genereux-jacques/manifeste-pour-l-economie-humaine-9022? folder $=2$. 
of technological radicalism and social conservatism, concepts began to emerge, the authors opposed to the technological revolution of the sociocultural changes. Certainly, speaking of the technology's role in the socio-cultural progress of civilization, one cannot fall into the extreme and one-sidedness associated with the exaggeration of the technology's role and its capabilities as perhaps the only tool of human progress. This is clearly and distinctly demonstrated by technocratic theories based on the doctrine of the transition of management and power in production and in society from owners and politicians to engineering and technical intelligentsia (technocracy) and management specialists who emerge as the main "driving force" of progress. Technocratic theories reflected the increasing importance of science and technology in social relations in the face of the scientific and technological revolution. On the basis of technocratic determinism, the principle of determining the role of technology in socio-cultural progress was formulated, the essence of which is that technology possesses "autonomy of development" (including in the sense of independence from sociocultural control), and technical development is understood as progress (in that sense, that all, without exception, technical innovations are progressive), which does not experience any deterministic influence on the part of other social phenomena, on the contrary, acting as the final determinant of all social transformations and cultures s modifications ${ }^{14}$. That is, a characteristic feature of technical optimism is the idealization of technology, the overestimation of its development potential: technology is seen as the sole or paramount determinant of socio-cultural progress.

Technical pessimism is characterized by the negation of technology and, accordingly, the finding of the crisis of modern civilization, responsible for declaring large-scale technological development and principles that underpin modern industrial and technological civilization: orientation to increasing consumption and the advantage of socio-cultural innovations. The increasing anthropogenic filling on the biosphere causes its compensatory potential to be on the verge, and therefore its transition to a new state unsuitable for human life is quite possible: "a catastrophe can explode completely unexpectedly and so quickly that no action can change anything" 15 . Representatives of technical pessimism are of the opinion that the techno genic environment "tightens, deforms and, finally, threatens the complete destruction of those areas that are either unique gifts of nature or unique gifts of culture", and as an alternative, increasingly call for the rejection of rational for the benefit of, alternatively, the

${ }^{14}$ Filosofiya tehniki. (2013). In Noveyshiy filosofskiy slovar. URL: https://www.gumer.info/ bogoslov_Buks/Philos/ New_Dict/852.p.

15 Moiseev, N. (1992). Prirodnyiy faktor i krizisyi tsivilizatsii. URL: http://ecsocman.hse.ru/data/817/ 807/1231/08-Moiseev.pdf. 
religious renewal of humanity, or the reduction of man-made load by limiting further technological growth. Thus, according to the estimates of M.M. Moiseev, a scientist known for his fundamental works in the field of modern rationalism, in order for mankind to be able to fit into the "natural" biosphere cycles, it is necessary to reduce the level of satisfaction of his needs by about 10, and the US in general 50 times $^{16}$. Some countries are trying to follow such recommendations, but in practice they are often faced with the situation of the strongest opposition, caused by uneven technological development of different regions, countries that develop their industry sees in expanding techno sphere only path to economic prosperity and technological leaders do not want to lose their advantage. In addition, some scientists, talking about the crisis, are forced to admit that leaving it is impossible without further development of such components of the process of civilization, as the development of productive forces, as well as the achievements of science and technology ${ }^{17}$.

Thus, without appropriate socio-cultural transformations of society, it is impossible to solve the economic and socio-cultural contradictions of modern techno genic society. In this connection, particular attention should be paid to such questions as the level of conformity of modern society to the modern level of techno genic civilization, whether the pace of rapid scientific and technological revolution requires the same rapid transformations of society, and whether it is the last stimulus of these transformations? Undoubtedly, scientific and technological progress in the modern world must create the technical and economic, material basis of socio-cultural progress, thus, being one of the important components of society's progress in the interests of all people, then the science and technology successful development can contribute to solving the complex of economic and social cultures the tasks facing civilization, the creation of material and spiritual preconditions for the comprehensive and harmonious development and realization of the potential of the individual and humanity as a whole.

It is important to understand that global problems of techno genic civilization are a consequence of a historically predetermined way of being human, in other words, global problems are a by-product of the person's vital activity who seeks to survive and realize him in the course of historical development. However, people's activities, in addition to the results that are considered optimal, have negative consequences, which have exceeded the critical mass by now. It is with scientific and technological development that the emergence of global problems is connected, and more precisely with

\footnotetext{
${ }^{16}$ Moiseev, N.N. (1997). S myislyami o buduschem Rossii. Moscow.

17 Obraschenie akademika Nikityi Moiseeva. (2012). URL: http://www.ccas.ru/manbios/ moistestam_r.html.
} 
technology that has reached the level of the ability to perform grandiose tasks of global influence, and technologies that have created a mechanism for the global impact of technology on the world around us: "a significant role in all global problems of 20th century history have been played by science and technology, which have added, in fact, this very global of events.

Originally technics was perceived as nothing more than a tool of work and the result of human activity, the improvement of which is aimed at solving all vital problems, as it develops, undergoes substantial changes that make it impossible to evaluate it unequivocally positively or negatively"18.

Most of the global problems and their connection with the techno genic civilization is most clearly demonstrated by the ecological crisis and as a result of the continuous interaction of the biosphere and techno sphere. Another source of global problems is the conflict between technology that comprehensively embraces human life and traditional cultural values, the traditional way of life, which ultimately leads to the emergence and rapid change of modern paradigms, problems in the education of entire generations, anthropogenic and mental changes, etc.

Thus, the Industrial Revolution led to a sharp rise in man-made burden on the biosphere, which, unfortunately, and it is regarded as an infinite reservoir of resources for technical activities, and it could not but cause concern of the international community. Human pressure on the environment has become incomparable with it, the environment, and its ability to resist. By its economic activity, the person constantly violates the basic principles of the natural structure of the biosphere: thermal balance, the cycle of substances formed, the species and biological communities diversity, population stability, etc. ${ }^{19}$ As a result, tense relationships between the techno sphere and the biosphere, expressed by the mismatch between the techno genic load and the biosphere's resources, have reached the ecological crisis level. The ways to solve the latter are reduced, mainly, to the halt of technological development and at least the reduction of the existing techno sphere (and often calls for a return to the "bosom of nature"), or to the strict control and regulation of techno genic development, especially potentially dangerous, in terms of technological possibilities catastrophes, productions. However, these measures should be combined with the simultaneous adaptation of humanity to the new socio-natural laws, although at best they will only be able to slow down anthropogenic degradation of the biosphere, but not stop it.

18 Sultanova, Zh.B. (2005). Tehnika kak osnovanie sovremennoy kulturyi. Filosofiya $i$ buduschee tsivilizatsii, 3, 553-554.

19 Lobanova, Z.M. (2009). Ekologiya i zaschita biosferyi. Barnaul. URL: http://lzm.users.altstu.ru/book/glava1.html. 
It is necessary to state that environmental ideas have not yet become the norm of technology development, so they should be given considerable attention.

The comprehensive impact of technology and techno culture on man, society and nature provoked a maturation and anthropological crisis, which covered the whole complex of human relationships. The person's behavior and his or her way of thinking change so much that the subject of anxiety was the degradation of the person himself or herself. Many see the way out of the crisis in the revival of spirituality and either in the form of traditional religions or in the form of developing and preaching a "new morality". But the practical implementation of these proposals is complicated by the same reasons that caused the ecological crisis: the widespread spread of technic and technology, including robotics, genetic engineering, and Nano and many other technologies that American scientist and programmer B. Joy calls evil in the extreme, which goes beyond the weapons of mass destruction ${ }^{20}$. But in trying to solve the problem of technical reality, some points should be taken into account: 1) technological development, not balanced with the interests of the biosphere, it is an objective process of realization of human nature, so that the global interaction of humanity as a whole is necessary to solve global problems; 2) the direction of techno genic development is further distancing new generations from the biosphere existence, and complete abandonment of technology is not only impossible but also harmful, making any attempts of people to "fit in" into the biosphere meaningless. Thus, a contradiction arises: humanity cannot live without the biosphere, and humanity cannot but change the biosphere. This is the main problem of modern civilization: how, as a person, to continue to realize its active and active nature? One of the members of the Roman Club E. Pestel offers an answer to this question: "not blind opposition to progress, but opposition to blind progress" 21 .

Met technologies are increasingly becoming a "second nature", forming boundaries and setting the conditions for the development of the individual and humanity as a whole. In a sense, the words "second nature", created by met technologies, will become for the information society the same external constraint and impetus to development that the original "first" nature was for the original community. The main feature of met technologies is that the society that consumes them automatically loses the opportunity to compete with the societies producing these technologies, providing their developer with strategic subjugation of anyone and anyone who uses these technologies. Further revolutionary changes in the development of information technology related to the information superhighways evolution, designed to supply a large

${ }^{20}$ Dzhoy, B. (2007-2011). Pochemu myi ne nuzhnyi buduschemu. In Globalnyie riski : sbornik statey. URL: https://www.proza.ru/2009/10/15/107.

${ }^{21}$ Pestel, E. (1987). Za predelami rosta. URL: http://alt-future.narod.ru/Future/rome3.htm. 
amount of information to its consumers on the basis of information infrastructure, to provide communication and information services ${ }^{22}$.

The revolution in the field of computer and telecommunication technology, which is the material basis of society's information, marks the beginning of a new process in cultural genesis, which can be defined as demassification. Instead of modern television and radio channels, systems are emerging not only multi-channel, but also providing unlimited possibilities for individual choice of business, household, political, cultural, educational information. Information causes the emergence of new technologies and models of activity, another type of culture, which are becoming a single "organism" through information.

Person is increasingly spending his or her leisure time in a virtual, computer-engineered world. There is a sense of unity of the machine with the user, and the action of virtual objects is perceived by a person similar to the "usual" reality. Virtual reality allows you to discover and create new dimensions of culture and society, to bring to life the idea of a multiplicity of worlds. In turn, cyberspace makes it possible to overcome the existential limitations of reality. Education and entertainment are the most promising areas of technology. At the same time, the global information technology industry (radio, television and the Internet) is contributing to an unprecedented increase in misinformation, which has a contradictory psychological effect on the society, its individuals.

Recognizing the full benefits of the information society, it cannot be ignored that it brings with it not only new solutions and opportunities, but also new problems and risks, such as the inability to intelligently comprehend large amounts of information and, in this regard, the loss of stability; information manipulation and related stress; monopolies in information technology as a way of exploiting developing countries; total information control and restrictions on the dissemination of information and the latest information technologies. In addition, the question arises: will people be able to adapt to these changes, are ICTs creating new jobs or destroying existing ones? Will the complexity and high cost of modern technologies increase the gap between industrialized and less developed countries, young and younger generations, those who can handle them and who do not know them? It is obvious that the transition to mass use of the latest information and telecommunication technologies will inevitably create serious social stress, will give technical opportunity to groups of people who own media and communication to a certain extent and if necessary to control the whole society in general and each person separately.

${ }^{22}$ Praktika globalizatsii: igryi i pravila novoy epohi (2003) / pod red. M.G. Delyagina. Moscow: "INFRA-M". URL: http://www.imperativ.net/iprog/deliagin.htm. 
Considering the potential of culture in this matter, it is its conservative component that should ensure in the rapidly changing external world the preservation of a stable, permanent essential component, which determines the purposeful progress of civilization and a common understanding of the nature and directions of the progress of humanity. In this movement, the most important criterion for the correctness of the chosen direction must be sociocultural progress. Given the growing socio-cultural importance of technology and technology, their assessment should be made as they contribute, above all, to the complex development of society. This should determine the general direction of scientific and technological progress.

\section{CONCLUSIONS}

Socio-cultural progress is largely related to the technology progress and its application in the science development. In technology, humanity has accumulated its centuries-old experience, techniques, methods of cognition and transformation of nature, accordingly, it should be perceived as a means of socio-cultural transformations. The importance and role of technology in the socio-cultural development throughout human history has steadily increased, reaching today, in the era of techno genic civilization, an unprecedented level. The most important characteristic of the modern stage of civilization development is, on the one hand, the active formation of the information society, and on the other, the same society, which is comprehensively and increasingly covered by technology, and it is increasingly technological. The interaction of technology, information and traditional culture and their joint influence on modern civilization is extremely complex, giving rise to many socio-cultural problems of today. However, disputes about the future of technology concern not so much technology as the civilization future. Humanity is vitally interested in the future of technology, understood as the only common phenomenon of human culture, which has become a factor that largely determines the future development. Of course, the search for protective mechanisms must meet the requirements of protecting the biosphere from the negative effects of scientific and technological progress, excluding the complete abandonment of technology.

The cause of many techno problems is the emergence of a gap between technology and culture; in the predominance of the paradigm of the science and technology dominant role in the general development of civilization in a rather large period of society, in the emergence of this "mass culture".

Therefore, the importance of the tasks and solutions to the problems facing cultural studies today requires the formation of a new paradigm of understanding and attitude to technology in society, including the definition of its role in contemporary culture and role among the instruments of sociocultural transformation. 
The spread of information technology, the emergence of a new information civilization requires the human values development designed to offset the impersonal nature of technology. In the information world one will have to cultivate humanity, strive for mutual understanding, to form a new picture of the world, civilizations. One of the fundamental principles in this movement should be the humanitarian understanding and use of technology from the standpoint of the public good.

\section{SUMMARY}

The article draws attention to the need to study techniques and technologies from the standpoint of cultural knowledge, which will allow overcoming the crisis in their attitude, to take into account their role in socio-cultural processes. Techniques and technologies are considered as the basis of techno genic civilization and as means of socio-cultural transformations. The latter are directly related to scientific and technological progress, in which the combination of science and technology has become a decisive factor in the engineering and technology rapid development. It is stated that the main characteristic of the scientific and technological revolution is not the great scientific discoveries, not the restructuring of the whole technological mode of production, namely obtaining on the basis of scientific and technological progress positive socio-cultural transformations. It is emphasized that engineering and technology should be considered as a phenomenon, as part of the culture of modernity, which significantly influences the spiritual values, socio-cultural relations of civilization, but nothing more. It is noted that a characteristic feature of technical optimism is the idealization of technology, the overestimation of its development potential: technology is regarded as the sole or paramount determinant of socio-cultural progress. Technical pessimism is characterized by the negation of technology and, accordingly, the finding of the crisis of modern civilization, responsible for declaring large-scale technological development and principles that underpin modern industrial and technological civilization: orientation to increasing consumption and the advantage of socio-cultural innovations. Considering the culture potential in the process of transition to mass use of the latest information and telecommunication technologies, it is its conservative component that should ensure in the rapidly changing external world the preservation of a stable, permanent essential component, which determines the purposeful progress of civilization and the general direction of movement and common sense. 


\section{REFERENCES}

1. Dzhoy, B. (2007-2011). Pochemu myi ne nuzhnyi buduschemu. In Globalnyie riski : sbornik statey. URL: https://www.proza.ru/2009/10/15/107.

2. Filosofiya nauki i tehniki. (2003) / pod red. V. V. Ilina. Moscow: Izdatel'stvo MGTU im. N. E. Baumana.

3. Filosofiya tehniki. (2013). In Noveyshiy filosofskiy slovar. URL: https://www.gumer.info/bogoslov_Buks/Philos/New_Dict/852.p.

4. Généreux, J. (2001). Manifeste pour l'économie humaine. Esprit, 7. URL: https://esprit.presse.fr/ article/ genereux-jacques/manifeste-pour-leconomie-humaine-9022? folder $=2$.

5. Khodykina, V.V. (2005). Mizhnarodna naukovo-tekhnichna integhracija Ukrajiny v konteksti strateghiji innovacijnogho rozvytku. $\mathrm{PhD}$ Thesis. Donecjk.

6. Lobanova, Z. M. (2009). Ekologiya i zaschita biosferyi. Barnaul. URL: http://lzm.users.altstu.ru/ book/glava1.html.

7. Moiseev, N. (1992). Prirodnyiy faktor i krizisyi tsivilizatsii. URL: http://ecsocman.hse.ru/data/817/ 807/1231/08-Moiseev.pdf.

8. Moiseev, N.N. (1997). S myislyami o buduschem Rossii. Moscow.

9. Obraschenie akademika Nikityi Moiseeva. (2012). URL: http://www.ccas.ru/manbios/moistestam_r.html.

10. Panarin, A.S. (2002). Iskushenie globalizmom. Moscow: EKSMOPress.

11. Pestel, E. (1987). Za predelami rosta. URL: http://alt-future.narod.ru/ Future/rome3.htm.

12. Praktika globalizatsii: igryi i pravila novoy epohi (2003) / pod red. M. G. Delyagina. Moscow: "INFRA-M". URL: http://www.imperativ.net/ iprog/deliagin.htm.

13. Rozin, V.M. (2006). Ponyatie i sovremennyie kontseptsii tehniki. Glava 5. Krizis tehnogennoy tsivilizatsii i puti vyihoda iz nego. URL: https://gtmarket.ru/laboratory/basis/ 5612/5617.

14. Rozin, V.M. (2018). Istoriya i filosofiya nauki. Moscow: "Yurayt".

15. Silichev, D. A. (2005). Sotsialnyie posledstviya perehoda ot industrializma i moderna k postindustrializmu i postmodernu. Voprosyi filosofii, 7. URL: https://elibrary.ru/item.asp? id=9138605.

16. Sultanova, Zh. B. (2005). Tehnika kak osnovanie sovremennoy kulturyi. Filosofiya i buduschee tsivilizatsii, 3, 553-554.

17. Trach, Yu.V. (2012). Informatsina revoliutsiia ta yii vlyv na kulturni protsesy v hlobalnomu masshtabi. Issues in Cultural Studies, 28, 122-129.

18. Trach, Yu.V. (2015). Vysoki tekhnolohii u konteksti istorychnoho rozvytku tekhnohennoi tsyvilizatsii. National Academy of Managerial Staff of Culture and Arts Heral, 3, 70-75. 
19. Vasilchuk, Yu.A. (1991). Epoha NTR: masshtabyi peremen. Polis, $1-3,53-67$.

20. Volkov, G.N. (2011). Nauchno-tehnicheskiy progress. In Bolshaya sovetskaya entsiklopediya. URL: https://dic.academic.ru/contents.nsf/bse.

Information about the author: Yuliia Trach, Candidate of Pedagogical Sciences, Professor, Director of the Research Institute, Kyiv National University of Culture and Arts, 36, Y. Konovalets str., Kyiv, 01133, Ukraine http://orcid.org/0000-0003-2963-0500 


\section{PART 2. POLYASPECTIVITY OF THE ART PHENOMENA}

DOI https://doi.org/10.36059/978-966-397-204-6/63-77

\section{THEORETICAL CONCEPTS IN THE PRACTICE OF THE SOVIET UKRAINE BALLET CRITICISM IN LATE 1920S}

\section{Alina Pidlypska}

\section{INTRODUCTION}

A holistic understanding of any kind of art is impossible without the study of its criticism, because the unity of theory, history and criticism is the key to the existence of art disciplines, including ballet knowledge. The fundamental studies of the Ukrainian prominent ballet scholars (L. Dolokhova, M. Zahaikevych, Yu. Stanishevskyi, A. Chepalov, etc.) are based on artistic criticism of various historical periods. The aforementioned authors themselves made a lot of efforts to develop the art-critical discourse of Ukraine. However, Ukrainian ballet criticism has not yet become the subject of a special study.

The transformation of the social and cultural sphere of Ukraine at the end of the XXth and beginning of the XXIst centuries, the collapse of the totalitarian Soviet regime, opening access to previously classified archival materials, changing value orientations made it possible to objectively reproduce the panorama of the ballet criticism development in Ukraine. The first steps in this direction have already been taken by us in previous publications ${ }^{1}$. New research allows us to deepen the subject of the study.

In the focus of the late 1920s Ukrainian criticism of the theatrical forms of art (Drama Theatre, Opera, etc.) ballet criticism gradually gained the right to independence. In that time the problems of the ballet repertoire updating in the Soviet Ukraine were the main issue in the discussions, associated with the diverge from the of Proletkult's (Proletarian cultural and educational organizations) ideological attitudes and the formation of a new aesthetic platform of Soviet art's formation. These were the conditions influencing the formation of the Ukrainian ballet criticism.

The aim of the study is to identify the main aspects of the Soviet Ukraine ballet criticism's development in late 1920s through the prism of general aesthetic concepts of art criticism.

${ }^{1}$ Pidlypska, A. (2019). Balety Kasiana Holeizovskoho "Iosyp Prekrasnyi" ta "Hrotesk" V Radianskii Ukraini druhoi polovyny 20-kh rr. XX st.: krytychnyi dyskurs. Dance Studies, 2, 2, 158-167. DOI: https://doi.org/10.31866/2616-7'646.2.2.2019.188816. 
Ukrainian ballet criticism as an independent phenomenon was formed in the field of art criticism, the search for a common aesthetic platform of which continued inseparably throughout the 1920s. The first part of the study is devoted to this aspect.

The Ukrainian ballet theatre criticism reflected ideological principles proclaimed by theorists and practitioners of the USSR cultural construction. In the depths of criticism there were formed certain aesthetic canons of the artistic value of works depending on the proximity to the "old ballet", as well as certain social and ideological attitudes. This issue is highlighted in the second part of the study.

\section{Aesthetic platform of art criticism on the pages of Ukrainian periodicals}

After the contradictory circumstances of the October Revolution or the "events of 1917" (according to A. Badiou) ${ }^{2}$, the national liberation struggle in Ukraine of the 1918-1921, the Politics of War Communism affected the cultural and artistic life of Ukraine, there began a period of certain stabilization, the search for a unified doctrine of cultural development.

The authorities recognized art criticism on the pages of the media (newspapers, magazines) as one of the important tools for introducing ideological principles in the artistic culture. A specialized theatrical journal "Nove mystetstvo" (New Art) (1925-1929) began to be published in Kharkiv in 1925. It became an important subject of the art-critical discourse of Ukraine. In the seventh issue for 1925, K. Rafalsky made an extensive article on criticism in the artistic life, recognizing the lack of attention to it. The author noted the dynamics of changes in the artistic development of society and the corresponding tasks of criticism, that must be considered and set in the general context of the state's tasks in the field of artistic policy, with that one of the 1925 being significantly different from the artistic policy of 1919-1920, and the latter not being like the art politics of 1917 and $1918^{3}$. The author proved the "ideologically artistic values" to be gradually replacing abstract revolutionary agitation in art and criticism. He understood the naturalness of moving away from a purely anti-art agitation, the pursuit of artistic value in the content and form of the work. Political and ideological attitudes are clearly visible in the publication: theatre and art criticism are positioned as one of the "most powerful tools of social reorganization", "the factor of educating the public". K. Rafalsky also considered criticism

${ }^{2}$ Abushkin, P.G. (2014). Revolyutsiya s tochki zreniya filosofii i politiki: teoriya sobytiya A. Badiou. Obshchestvo: filosofiya, istoriya, kul'tura, 2, 20-24.

${ }^{3}$ Rafalskyi, K. (1925). Krytyka. Nove mystetstvo, 7, 1. 
to be an important factor in the art propaganda, which should be on the path of a deeper, thoughtful approach to artistic life, under the sign of the increased artistic demands ${ }^{4}$.

One of the key issues of the Soviet cultural policy was treating the attitude to opera, ballet, and musical art. In the USSR, in a difficult situation of the early 1920s, opera and ballet were perceived as "remnants of the past". Throughout the 1920s, the issue of one or another classic, or a work of classical art "usefulness" for a new society remained the subject of active debate. However, the main thing was that the "bourgeois cultural heritage" elimination responded to the Proletkult and avant-garde's directions to creating a new "revolutionary art". Thus, the Proletkult and avant-garde brought together utopian intentions and projects for the society's reconstruction, with this "new art" being an important factor of which.

Mid 1920s was the time when the Proletkult attitudes regarding the artistic heritage still dominated, but given the external and internal social and political factors, they were gradually losing influence. In 1925, to develop a unified cultural policy in the USSR, there was founded "Sovetskoe iskusstvo" (Soviet Art) magazine (Moscow). In its first issue the magazine's editor-in-chief stated that the old principles [of bourgeois aesthetics] had been destroyed, new ones had not yet been created ... there was no theory, and the revolution would be pathetic without the theoretical foundation of scientific socialism ${ }^{5}$. And in these conditions, one of the ways of stabilization was to appeal to the theatrical repertoire of the past.

In 1926 answering the question of the classical repertoire acceptance from the Marxism point of view, the famous philosopher and art critic M. Lifshits remarked that it was necessary to practice the old repertoire reworking. Although in the future the emergence of new things that meet new needs and increase the mass cultural level in our country, would allow the release of classical works without changes ${ }^{6}$.

According to M. Lifshitz, when reworking, there were two circumstances to be taken into account. The first one was the truly classical works, with a specific period of the mankind's development been reflected in, needed reworking not because they were outdated, but because they needed to be made accessible to viewers, which in turn was aimed at further promoting them. At the same time, M. Lifshits warned that it was necessary to remember

\footnotetext{
${ }^{4}$ Rafalskyi, K. (1925). Krytyka. Nove mystetstvo, 7, 1.

${ }^{5}$ Pel'she, R. (1925). O edinoi khudozhestvennoi politike (k postanovke voprosa). Sovetskoe iskusstvo, 1, 10-12.

${ }^{6}$ Lifshits, M. (1926). Dopustimy li s tochki zreniya marksistskoi estetiki peredelki veshchei klassicheskogo repertuara? Programmy gosudarstvennykh akademicheskikh teatrov, 55, 4. URL: http://www.gutov.ru/lifshitz/mesotes/ zper.htm.
} 
which imperceptible line separated popularization from vulgarization and how noticeable there were its slightest violations. Secondly, according to the critic, a classical work reproduction was in its transcription ${ }^{7}$. Since it was impossible to change the essential, historical content of a work without violating its artistic merit, but changes were accessible when they contributed to the disclosure of its content. But this, according to M. Lifshitz, did not mean that preference was given to the cognitive side of art over the effective one. There was no need to admire the superficial revolution, but very carefully to apply the materialistic interpretation of the classical heritage, while maintaining the true meaning of the work.

Discussions about the aesthetic canons and the Marxist foundations of artistic activity and its criticism reached Ukraine as well. M. Khrystovyi considered the arsenal of Marxist principles while developing the theory of art criticism, proving the educational role of art criticism. He said that the criticism should express artistic tendencies to the class, the artistic tendencies of our era society's organizer - the proletariat. Briefly speaking, the criticism of that time was to be Marxist ... It was the time of developing Marxist criticism... it was necessary to find and educate the specialists of the Marxist criticism in general and theatrical in particular ${ }^{8}$. Without being immersed in the ideas of Marxism, the writer used this term as a certain stamp, imparting it with the features of ideological reliability, correctness.

The author claims that theatrical criticism to be a socially necessary factor in building a socialist culture; the critic was to be able to correlate his thoughts and impressions with the tasks of the time, the general theatre policy. M. Khrystovyi was sure that art criticism had never been so popular anywhere; there had never been such a mass consumer as the proletariat before. Orienteering to the masses a priori deprived artistic criticism of elitism, deep artistic content, interpretative features and the like. According to the author of the article, ideological relevance and social importance should have become the main evaluation parameters for the critics.

The seventh issue of the "Nove mystetstvo" magazine for 1926 contained an article "Znovu y znovu pro te same" (Once again about the same) (unfortunately, the author was not indicated) ${ }^{9}$. The article stated the art criticism lacking sustainable methods and any principles and expressive line of work. There were expressed some concerns about the lack of a single methodological guideline. There was felt an attack on personal and individual

7 Lifshits, M. (1926). Kakogo roda peredelki veshchei klassicheskogo repertuara v nastoyashchee vremya dopustimy dopustimy i zhelatel'ny? Programmy gosudarstvennykh akademicheskikh teatrov, 59, 6. URL: http://www.gutov.ru/ lifshitz/mesotes/zperv.htm.

${ }^{8}$ Khrystovyi, M. (1926). Pro nashu teatralnu krytyku. Nove mystetstvo, 25, 1-2.

${ }^{9}$ Znovu y znovu pro te same. (1926). Nove mystetstvo, $7,1$. 
manifestations in the critics' statements. The author believed that the theater reviews were full of too many "coincidences", "individual taste domination", "nepotism". He openly opposed individual sympathies, aesthetism and idealism in art and criticism, considered them to be the legacy of the bourgeois social order.

The author refers to the resolution of the Central Committee of the Communist Party of the Soviet Union (without naming it) "On Party Policy in the Field of Fiction" (1925), which became important for the country's further cultural development. The criticism's tasks were formulated here: it (criticism) was one of the main educational tools in the hands of the party ${ }^{10}$. According to the resolution, it was argued that criticism would become the educator of society when armed with sustainable scientific methods and based on its ideological superiority. The author appealed to Marxist ethics, which denies individual tastes, insists on the critics to use the scientific Marxist method. There was a call for the elimination of unprincipled, eclecticism, prerevolutionary bourgeois heritage, as well as a radical change in the principles of critical approach to theater and methods of work.

The author saw the mission of criticism to be not only in the analysis of works. A critic should be a "judge of art", "the most important factor in the organization of psychology of the masses". The starting points for criticism should be "ideology of the time", "social and public value", "class nature" (reflecting the class ideology of the proletariat), "focus on the present"

The problem of the theoretical foundations of art criticism was not limited to discussions on the newspaper pages; it was regularly solved in the USSR in a normative way. In addition to the aforementioned resolution, there were issued a number of documents on art criticism, in particular, at the end of December 1926, the Press Department of the Bureau of the Central Committee of the Communist Party of the Soviet Union approved the Thesis on Theatre Criticism ${ }^{12}$. In addition to various explanations for the role of art criticism in Soviet society, there were also suggested ways of combating substandard criticism. Any manifestation of hack-work, illiteracy, or lack of education ledge in the field of theatrical criticism, hidden under the poorly mastered Marxian phraseology and aplomb, being completely opposite and not corresponding the real the art tasks and politics of the party, should be

${ }^{10}$ Babichenko, D.L. (ed). (1997). "Schast'e literatury": Gosudarstvo i pisateli, 1925-1938. Dokumenty. Moscow: ROSSPEN.

${ }^{11}$ Znovu y znovu pro te same. (1926). Nove mystetstvo, 7, 1.

${ }^{12}$ Tezy pro teatralnu krytyku (Zatverdzheni Viddilom druku Biuro TsK VKP(b) 29 hrudnia 1926 roku). (1927). Nove mystetstvo, 4, 14-15. 
mercilessly pursued and pulled out from usage ${ }^{13}$. These theses were full with tyrannical tendencies, gradually rooting in life.

Thus, in the late 1920s Ukraine as a part of the USSR began to search for a methodological basis for artistic criticism, which had already departed from the anti-artistic agitation of the proletariat, but still was not oriented to axiological and epistemological principles.

\section{Ideological attitudes reflected in the Soviet Ukraine ballet criticism}

Proletkult's attitudes towards revolutionary, "new art" contrasted with the artistic essence of ballet theatre, where conservatism and traditionalism became the key to the very concept of "ballet". Ballet, being in its essence an elitist, aristocratic art, did not fit into the strategy of a new reality construction as a "revolution in art".

As for the propaganda direction of choreographic activity, it, given the worldview incompatibility of many recognized ballet masters with the requirements of proletarian culture, caused persistent rejection and even resistance. However, the propaganda of political ideas by means of art was the first and main direction, supported by the new government, and "the effectiveness of art", at the same time, was determined by its "propaganda power, the ability to effectively incorporate into reality" ${ }^{14}$.

The mid 1920s period of experiments in choreographic art ended with the closure of a number of dance studios and theatres, with the press launching campaigns to return the Soviet culture and art to the previous century traditions. It primarily concerned realism; with the movement "to learn from the classics" gaining its momentum.

Classical ballet, the basis of which is classical dance as an established set of poses, movements, gestures and visual means, is strictly conventional. There are two ways to break this convention: deviate from classical dance, as Isadora Duncan did, or try to invent your own micro-convention inside classical dance (ballet). The need to preserve this conventionality was also understood by A. Lunacharsky. According to him there were people saying that the classical ballet school was a product of the ancient past. As people would mainly need dances depicting true performance, past dramatic or dance in the proper sense, there was no need for ballet at all. Thus, artificial "classic" was out of needed. But during A. Lunacharsky's time as a theatre

\footnotetext{
${ }^{13}$ Tezy pro teatralnu krytyku (Zatverdzheni Viddilom druku Biuro TsK VKP(b) 29 hrudnia 1926 roku). (1927). Nove mystetstvo, 4, 14-15.

${ }^{14}$ Napreenko, G. \& Novozhenova, A. (2018). Epizody modernizma: ot istokov do krizisa. Moscow: Novoe literaturnoe obozrenie.
} 
and art educator, he was always afraid of breaking the traditional line, because once it been lost, anybody would never find it again. In case the Russian classical dance, being at such a high altitude with no one daring to equal, be destroyed, then not only ballet lovers, but, possibly, proletarian youth would cry with bitter tears ${ }^{15}$. The preservation of the acquired and reforming the individual components of classical ballet became an ideological setting that determined the ways for the further development of the opera and ballet theatres' repertoire and, in general, the classical basis of the USSR ballet.

Amid unprecedented social and cultural transformations, well-known theatre critic I. Sollertinsky sought to preserve the great achievements of classical ballet, realizing its unique artistic value. Therefore, having sufficiently mastered political rhetoric, he participated in new values promotion, a new way of life, the ideals of the revolution and the communist future of the country. Thus, when considering the fifteen-year path of the ballet and opera theatre development in the History of the Soviet Theatre, published in 1933, with reconstruction (reduction or sovietisation, interpretation) being a relevant issue, the central problem of the military communism era was considered to be the "development of the opera-ballet heritage left over from autocratic, landowner and capitalist Russia. The critic noted that although the opera and ballet theatres "lived in classics and heritage", they were fundamentally distinguished from those ones of the previous years by their orientation "to the new multi-million proletarian audience". Thus, both I. Sollertinsky and M. Lifshitz talked about bringing classical ballets closer to the audience.

Regarding the performances of classical ballet heritage in Soviet ballet, two strategies could be distinguished: authentic reproduction of the author's version (restoration) and interpretation of the ballet performance according to ideological prescriptions of party instances.

In 1923-1924 F. Lopukhov, in the early 1920s standing up for the authentic reproduction of the author's text and defending the old repertoire, was one of the first Soviet choreographers to perform the restoration of "The Nutcracker" and "Sleeping Beauty" on the stage of the Mariinsky Theater. But this work caused controversial reviews. On the press pages K. Goleizovsky accused him that F. Lopukhov, as a director, was pulling the ballet of the Mariinsky Theatre back to bygone times ${ }^{16}$. And this was not surprising, because the K. Goleizovsky's creative work at that time became an

\footnotetext{
${ }^{15}$ Lunacharskii, A. (1958). Novye puti opery i baleta. In V mire muzyki. Moscow: Sovetskij kompozitor (pp. 399-417). URL: http://lunacharsky.newgod.su/ lib/v-mire-muzyki/-novye-putiopery-i-baleta/.

${ }^{16}$ Lopukhov, F. (1966). Shest'desyat let v balete. Vospominaniya i zapiski baletmeistera. Moscow : Iskusstvo.
} 
innovative breakthrough in the aesthetics of Soviet ballet, but it was aggressively perceived and did not take root.

The staff of the State Ukrainian Opera (Kharkiv) operated within framework of the first strategy. On October 25, 1925, the premiere of P. Tchaikovsky's "Swan Lake" ballet was staged by R. Balanotti. The latter sought to preserve the L. Lavrovsky and M. Petipa's choreography as accurately as possible ${ }^{17}$.

Oddly enough, but the new audience liked the "old" ballet. According to Yu. Yakovleva, despite all the feverish proposals of the Proletkultists, the public did not want to see the Dawn of the Revolution instead of Princess Aurora ${ }^{18}$.

The signs of the second strategy of attitude towards the ballet heritage (total renewal) are observed in the author's interpretation of M. Moiseev, the new choreographer of Kharkov State Opera. In March 1926 he staged the "Le Corsaire" ballet to the music of A. Adam ${ }^{19}$. According to a contemporary, the director's approach to the "Le Corsaire" ballet was a healthy dance without its refinement and decadence ... He (director) gave the ballet an original interpretation, rejecting the stencil of Moscow theatres' old productions ${ }^{20}$. The author of the review clearly expressed his position regarding the ballets of the past. He considered the choreography of that time to be "sick", refined and decadent, seeing the prospects for the ballet development in a total update, manifested not only in choreography, but also in all components of the ballet. In the fifth picture of the act the choreographer staged a flying ballet and addressed to moving planes ${ }^{21}$. The reviewer was in the position of "new art", striving for a "new reality" in ballet.

The decoration by A. Petrytsky, created without the use of designs, was typical of the theatrical scenography of that time. In the aesthetic principles of the article's author, the Proletkult attitudes were felt to emphasize the human body's beauty, depriving of the national identification signs. The reader's attention was drawn to the absence of "ethnography" in the sets and costumes. It was felt that the writer positively perceives that the costumes emphasized not the nationality, but the features of the human body.

After the "Le Corsaire" premiere, there appeared a new review by I. Turkeltaub in "Nove Mystetstvo" magazine. The author enthusiastically discussed about the variety of colours and paints of the ballet's decoration,

17 Stanishevskyi, Yu. (1986). Baletnyi teatr Radianskoi Ukrainy: 1925-1985: Shliakhy i problemy rozvytku. Kyiv : Muzychna Ukraina.

18 Yakovleva, Yu. (2017). Sozdateli i zriteli. Russkie balety epokhi shedevrov. Moscow: Novoe literaturnoe obozrenie.

${ }^{19}$ B. (1926). Do postanovky baleta "Korsar". Nove mystetstvo, 7, 3.

${ }^{20} \mathrm{Ibid}$.

${ }^{21}$ Ibid. 
where each picture was created in a different style. The author called the costumes a real "feast for the eye".

The choreography was recognized as masterful. I. Turkeltaub considered the compositional construction logical, the choreography organically interacting with the music, the pantomime revealing the plot, the characters being endowed with characteristic features. But the reviewer noted the lack of the mass scenes drawings, the excessive static of the corps de ballet in individual scenes. And this manifested the features of the future ballet aesthetics, when in the early 1930s the masses would become the main force in the performances, the driving force of the plot (for example, "Flames of Paris", choreographed by of V. Vainenen to music by B. Asafyev, Leningrad, 1932).

I. Turkeltaub noted the widespread use of purely dance moments, supported the stylization of dances, depriving the performance of a conservative stencil ${ }^{22}$. The reviewer dwelled on the individual characteristics of the performers: he considered the Siamese dance performed by Somova and Maslova to be rhythmically complex and the dance of the prima ballerina Salnikova in the image of Medora to be technically perfect. Whatever Salnikova did, it was full with lightness and elevation; it had a clear rhythm and very firm pointes. In "Le Corsaire" Salnikova was magnificent and completely captured the audience with a complicated "frapper" combined with "fouettes" ${ }^{23}$. I. Turkeltaub was one of the few who carefully and comprehensively analysed the lexical and choreographic details of the ballet using professional dance terminology. Unfortunately, such an art criticism approach was rare for Soviet Ukraine's critical ballet discourse of the late 1920s, because theatrical and musical critics, who were not deeply aware of the choreographic art nuances, used common stamps when evaluating the art of works.

I. Turkeltaub also emphasizes the shortcomings of the performance, considering the "flying ballet" to be unsuccessful and the last act shipwreck organization to inappropriate. The reviewer considered the musical decision of the ballet to be strange. Namely, the conductor A. Weissenberg used an Overture from the Wagner's "The Flying Dutchman" Opera, processed by Tolstiakov, as an introduction to the "Le Corsaire" 24 .

In the mid-1920s, most of the reviews were still saturated with the Proletkult's attitudes to the ballet classics. For example, an Odesa critic, who signed as Largo, accused the Odesa Opera House ballet of constantly referring to the repertoire of the past. According to him, "Le Corsaire's" plot with its musty musical content

\footnotetext{
${ }^{22}$ Turkeltaub, I. (1926). "Korsar". Nove mystetstvo, 10, 7.

${ }^{23}$ Ibid.

${ }^{24}$ Ibid.
} 
brought nothing to the heart or the head ${ }^{25}$. The critic, although not denying the usage of the ballet heritage for creating new performances, noted that, except for "Swan Lake", there was not any attempt to address to great ballet literature published before and after the October period ${ }^{26}$.

The concepts of the Proletkult were gradually losing their influence, thus affecting the idea's cultivation of the parity importance in the repertoire of traditions and innovations. However, critical publications put forward requirements for new ballet performances not from the point of view of artistry, but from the standpoint of social accessibility, orientation to the taste of workers; although the educational aspect of art was not left behind. The educational function was understood from the perspective of the collectivism's cultivation, but not from the point of the individual personality characteristics' identification and development. Recognizing all the financial risks of introducing a new repertoire, experiments that the viewer simply would not attend, critic Largo emphasized the task of the Soviet theatre to educate the new formation while noting that the theatre shouldn't focus exclusively on the audience in the art work ... it should adapt to the dynamics of that day's theatre life ${ }^{27}$ ".

The forerunners of the new Soviet art in Ukraine were the ballets to music of S. Vasilenko "Joseph the Beautiful" and "Grotesque", staged by K. Goleizovsky in 1926 in Odesa and in 1928 in Kharkov. However, according to critics, they did not fit into the canons of ideology and orientation towards the mass working viewer and were accused of aesthetics ${ }^{28}$.

In full accordance with the ideological guidelines of the time, there was developed the ballet of R. Glier's "Red Poppy" (first staged in Moscow on the stage of the Bolshoi Theatre in the summer of 1927, by ballet masters V. Tikhomirov and V. Lashchilin). It was proclaimed to be the first Soviet ballet in the Soviet historiography ${ }^{29}$. Already in December 1927, the premiere of "Red Poppy", staged by M. Moiseev, was held in Kharkiv. Compared to the ballet performance that took place in Moscow in 1927, the Kharkiv one was marked with significant changes. According to the Nevermore reviewer despite the general impression of novelty of choreography and scenography, it closely related to the forms and means of the old ballet. The critic admitted

${ }^{25}$ Largo. (1928). Odeskyi derzhavnyi opernyi teatr. Nove mystetstvo, 13, 6-7.

${ }^{26}$ Ibid.

${ }^{27}$ Ibid.

${ }^{28}$ Pidlypska, A. (2019). Balety Kasiana Holeizovskoho "Iosyp Prekrasnyi" ta "Hrotesk" v Radianskii Ukraini druhoi polovyny 20-kh rr. XX st.: krytychnyi dyskurs. Dance Studies, 2, 2, 158-167. DOI: https://doi.org/10.31866/2616-7'646.2.2.2019.188816.

${ }^{29}$ Stanishevskyi, Yu. (1986). Baletnyi teatr Radianskoi Ukrainy: 1925-1985: Shliakhy i problemy rozvytku. Kyiv : Muzychna Ukraina. 
compliance with the ideological requirements of modern times, but blamed the presence of "pure ballet aesthetics". He noted that was thanks to the "dreams", which gave pure classical dance, as well as splendour and fabulousness, ordinary adagio and variations been introduced, etc. All these were the attributes of old ballet art. The fear of breaking the age-old traditions of the ballet art was felt in everything ${ }^{30}$. The reviewer had a positive attitude not to pure dance, but to pantomimes or mimodramas. There were signs of admiration for the choreodrama, which from the beginning of the 1930 would become firmly entrenched on the Soviet ballet stage, slowing the down the ballet dancing development, in fact choreographic forms themselves.

The reviewer considered A. Moiseev production to be more successful than the Moscow one, that been facilitated by A. Petritsky's artistic stage design. The latter managed to mechanize the permutations as much as possible, using theatre technique extensively. A. Petritsky's rich colourful costumes left a vivid impression; especially original and workshop costumes with wings. Therefore, it was not surprising that the artist's work caused unanimous applause of the audience. Nevermore noted that no one could accuse the artist of aesthetics because it was not conditioned by the ballet itself ${ }^{31}$.

The reviewer also praised the choreographer, but his attention was also drawn to the weak mass-scenes of pantomime, which, in their static and lack of proper choreographic solution, were similar to the opera mass scenes.

A unique performance of this period was the production of "Tales of a Jester" by M. Diskovsky to music of S. Prokofiev at Kyiv Opera and Ballet Theatre in 1928. According to F. Malkov, the original production showed significant creative opportunities and prospects for the Ukrainian ballet theatre, how far modern ballet had gone with its libretto and music content from ceremonial ballet performances of the past ${ }^{32}$.

In late 1920s, despite the fact that the Soviet government was no longer sought to get rid of the classical heritage, but, on the contrary, to use its "great aesthetic power" as a "powerful weapon" 33 for its own purposes, the main evaluation criteria for the reviewers was either presence or absence of ties with ballet of the past.

30 Nevermore. (1928). Balet "Chervonyi Mak" v Kharkivskii Derzhavnii Operi. Nove mystetstvo, 1, 6-7.

${ }^{31}$ Ibid.

32 Malkov, F. (1928). "Kazka pro blaznia, shcho simokh blazniv peremudryv". Nove mystetstvo, 8, 7 .

${ }^{33}$ Lunacharskii, A. (1958). Novye puti opery i baleta. In $V$ mire muzyki. Moscow: Sovetskij kompozitor (pp. 399-417). URL: http://lunacharsky.newgod.su/ lib/v-mire-muzyki/-novye-putiopery-i-baleta/. 
The complexity and tragedy of the Soviet ballet formation process, including ballet criticism, with the interpretations of classical ballets and original works prevailing, was determined by the search for a special way of ballet development in the conditions of the increasing the state's role in the artistic process, the desire to control the course of the latter. Thus, there began and was spreading the process, while defining which one can refer the concept of the German literary critic Hans Gunther "nationalization" - "the ballet nationalization", which resulted in the "Soviet ballet" concept emergence, and more broadly - "the dance art nationalization".

\section{CONCLUSIONS}

In late 1920s the Soviet Ukraine art criticism departed from anti-artistic agitation and was searching for a theoretical basis for its continued existence. The methodological field of art criticism was formed by discussions unfolding on the pages of social and political and specialized periodicals (for example, the "Nove Mystetstvo" theatre weekly, published in Kharkiv in 1925-1928), as well as normative documentation (resolutions, resolutions of party and governmental agencies). The very presence of discussions was an important progressive sign of the times, because the next decade lost this opportunity for the USSR critics.

Gradually, critics increasingly came to define a limited range of tasks, instead of simply discussing a wide range of meaningful and functional attributes. Among the leading ones there were recognized social (tools of social adjustment), educational, propaganda functions of art criticism. The critic was required to obey the general ideological guidelines, to focus on the mass reader. The main evaluation criteria for this or that artistic phenomenon were class affiliation, true ideology, social and public value, modernity. Art criticism was proclaimed to be an effective factor in cultural construction.

In late 1920s, the apologists of Marxist ethics in art criticism insisted on the relevance of criticism to the public interest. Marxist ethics, within the framework of the Soviet art criticism concept development, became a dogma that for many years banned personality-oriented evaluative canons, made it necessary to consider works of art from a position of social significance. The objections of transferring the critics' individual tastes turned them solely into an ideological mouthpiece and an instrument of reprisal.

With the opening of Kharkiv State Opera Theatre in 1925, the functioning of Odesa and Kyiv Opera Houses, where ballet performances were staged, ballet critics became intensified. Accordingly, two approaches to the ballet heritage (one is periodical reference, minor editing, preservation of traditions; the other is a total reworking of everything related to the ballet of the past) in the criticism formed an evaluation criterion. The overwhelming majority of 
ballet critics drew attention to the presence or absence of communication with the ballet of the past, which was a manifestation of the Proletkult's certain features dominance.

Among the ballet performances that became the object of the critics' attention there were "Swan Lake" (with minimal revisions, the maximum preservation of the early XX century classical performance text), "Le Corsaire" (a significant degree of reworking, compared to the classical primary source), "Joseph the Beautiful" and "Grotesque" (innovative ballet performances transferred from the Moscow stage, minimally adapted to the conditions of Odesa and Kharkiv theatres),"Red Poppy" (a considerable degree of originality), "Tale of a Jester" (original production). A wide thematic and lexical palette of ballets in late 1920s Soviet Ukraine testified the considerable creative potential of Ukrainian ballet.

Gradually, ballet critics moved away from the revealing the epistemological and axiological aspects of the works and turned to the search for the social and educational role of the performances.

In general, Ukrainian critical art discourse underwent transformations and gradually turned into a product of political and ideological determination.

\section{SUMMARY}

A comprehensive understanding of any kind of art is impossible without studying its criticism, because the unity of theory, history and criticism is the key to the existence of the art disciplines, including ballet knowledge. In the focus of the late 1920s Ukrainian criticism of theatrical art forms, ballet criticism gradually gained the right to independence.

The art criticism of that time departed from anti-artistic agitation and was searching for a theoretical basis for its continued existence. The methodological field of art criticism was formed by discussions unfolding on the pages of social and political and specialized periodicals, as well as by specialized and normative documentation (decrees, resolutions).

The main evaluation criteria for this or that artistic phenomenon were class affiliation, true ideology, social and public value, modernity. Art criticism was proclaimed to be an effective factor in cultural construction.

Marxist ethics, within the framework of the Soviet art criticism concept development, became a dogma that for many years banned personalityoriented evaluative canons, made it necessary to consider works of art from a position of social significance, and denied transferring the critics' individual tastes.

With the opening of Kharkiv State Opera Theatre in 1925, the functioning of Odesa and Kyiv Opera Houses, where ballet performances were staged, ballet critics became intensified. Accordingly, two approaches to the ballet 
heritage (one is periodical reference, minor editing, preservation of traditions; the other is a total reworking of everything related to the ballet of the past) in the criticism formed an evaluation criterion. The overwhelming majority of ballet critics drew attention to the presence or absence of communication with the ballet of the past, which was a manifestation of the Proletkult's certain features dominance.

In general, Ukrainian critical art discourse underwent transformations and gradually turned into a product of political and ideological determination.

\section{REFERENCES}

1. Abushkin, P.G. (2014). Revolyutsiya s tochki zreniya filosofii i politiki: teoriya sobytiya A. Badiou. Obshchestvo: filosofiya, istoriya, kul'tura, 2, $20-24$.

2. B. (1926). Do postanovky baleta "Korsar". Nove mystetstvo, 7, 3.

3. Babichenko, D.L. (ed). (1997). "Schast'e literatury": Gosudarstvo i pisateli, 1925-1938. Dokumenty. Moscow: ROSSPEN.

4. Gunther, H. (1984). Die Verstaatlichung der Literatur. Entstehung und Funktionsweise des sozialistisch-realistischen Kanons in der sowjetischen Literatur der 30er Jahre. Stuttgart.

5. Khrystovyi, M. (1926). Pro nashu teatralnu krytyku. Nove mystetstvo, $25,1-2$.

6. Largo. (1928). Odeskyi derzhavnyi opernyi teatr. Nove mystetstvo, 13, $6-7$.

7. Lifshits, M. (1926). Dopustimy li s tochki zreniya marksistskoi estetiki peredelki veshchei klassicheskogo repertuara? Programmy gosudarstvennykh akademicheskikh teatrov, 55, 4. URL: http://www.gutov.ru/lifshitz/mesotes/ zper.htm.

8. Lifshits, M. (1926). Kakogo roda peredelki veshchei klassicheskogo repertuara $\mathrm{v}$ nastoyashchee vremya dopustimy dopustimy i zhelatel'ny? Programmy gosudarstvennykh akademicheskikh teatrov, 59, 6. URL: http://www.gutov.ru/ lifshitz/mesotes/zperv.htm.

9. Lopukhov, F. (1966). Shest'desyat let v balete. Vospominaniya i zapiski baletmeistera. Moscow : Iskusstvo.

10. Lunacharskii, A. (1958). Novye puti opery i baleta. In $V$ mire muzyki. Moscow: Sovetskij kompozitor (pp. 399-417). URL: http://lunacharsky.newgod.su/lib/v-mire-muzyki/-novye-puti-opery-i-baleta/.

11. Malkov, F. (1928). "Kazka pro blaznia, shcho simokh blazniv peremudryv". Nove mystetstvo, 8,7 .

12. Napreenko, G. \& Novozhenova, A. (2018). Epizody modernizma: ot istokov do krizisa. Moscow: Novoe literaturnoe obozrenie. 
13. Nevermore. (1928). Balet "Chervonyi Mak" v Kharkivskii Derzhavnii Operi. Nove mystetstvo, 1, 6-7.

14. Pel'she, R. (1925). O edinoi khudozhestvennoi politike (k postanovke voprosa). Sovetskoe iskusstvo, 1, 10-12.

15. Pidlypska, A. (2019). Balety Kasiana Holeizovskoho "Iosyp Prekrasnyi" ta "Hrotesk" v Radianskii Ukraini druhoi polovyny 20-kh rr. XX st.: krytychnyi dyskurs. Dance Studies, 2, 2, 158-167. DOI: https://doi.org/10.31866/2616-7'646.2.2.2019.188816.

16. Pidlypska, A. (2019). Sotsrealistychnyi kanon ta baletna krytyka seredyny 30-kh rr. XX st. National Academy of Managerial Staff of Culture and Arts Herald, 3, 347-352.

17. Rafalskyi, K. (1925). Krytyka. Nove mystetstvo, 7, 1.

18. Stanishevskyi, Yu. (1986). Baletnyi teatr Radianskoi Ukrainy: 1925-1985: Shliakhy i problemy rozvytku. Kyiv : Muzychna Ukraina.

19. Tezy pro teatralnu krytyku (Zatverdzheni Viddilom druku Biuro TsK VKP(b) 29 hrudnia 1926 roku). (1927). Nove mystetstvo, 4, 14-15.

20. Turkeltaub, I. (1925). Za naukove vyvchennia mystetstva. Nove mystetstvo, 5, 2.

21. Turkeltaub, I. (1926). "Korsar". Nove mystetstvo, 10, 7.

22. Yakovleva, Yu. (2017). Sozdateli i zriteli. Russkie balety epokhi shedevrov. Moscow: Novoe literaturnoe obozrenie.

23. Znovu y znovu pro te same. (1926). Nove mystetstvo, 7, 1.

\section{Information about the author:}

Alina Pidlypska,

Candidate of Arts, Professor, Professor of the Choreographic Art Department, Kyiv National University of Culture and Arts, 36, Y. Konovalets str., Kyiv, 01133, Ukraine http://orcid.org/0000-0012-9706-0306 


\section{THE UKRAINIAN DANCE ON THE STAGE AND IN THE HOUSEHOLD CULTURE OF THE NATION: CURRENT ISSUES}

\section{Olha Boiko}

\section{INTRODUCTION}

The construction of a modern society in post-colonial Ukraine has peculiarities in the aspect of culture, in particular choreographic, due to historical factors. Describing the XIX century as a unique period of national history, G. Skrypnyk emphasizes: "The decisive role in the preservation of ethnicity and in the national solidarity processes of the society was played by ethnic culture, which came under this time a fully developed, holistic system with peculiar characteristic features of its genres and artistic and stylistic characteristic"1. The artistic values of ethno culture were largely preserved and developed in the folk-stage choreography of the Soviet era, when, by changing ideological accents, the government tolerated the populist traditions of the XIX - early XX centuries. In the era of state independence, Ukrainian choreographic culture entered, preserving the rich artistic heritage of the past, often lost by developed countries of Western Europe. The new cultural reality is characterized by the overcoming of the ethnography inherent elements in the populist approach, as well as the rudiments of the leveling national identity of the "socialist realism method", but the scientific community has not yet developed a consolidated opinion on the role and place of folk choreography in a modern model of the culture. This leads to a deeper study of the problem of preserving and developing the national choreographic heritage in the context of the leveling impact of globalization, and leads to the idea that the answer to the question: "What is contemporary choreography?" foreign dances, but also in the complex interaction of traditions and innovations, ambiguous, diverse and multifaceted transformation of folk dance, in general, the transformation of cultural codes and regional and local cultural canons.

Turning to the corner in choreology problem of the traditions interaction and innovations, Ukrainian researchers reject unilateral approaches; in particular, formed in Soviet art studies under the influence of ideological factors, interpret the dialectics of the interaction of traditions and innovations as the driving force

\footnotetext{
${ }^{1}$ Skrypnyk, H.A. (2008). Istoriia ukrainskoi kultury: u 5 tomakh. T. 4. Kn. 1. Kyiv: Naukova dumka.
} 
for the development of national culture. "Innovation is not a radical denial or destruction of a tradition and it can be an improvement or refinement of it," $\mathrm{K}$. Kyrylenko notes. - Tradition, in its turn, is not something that remains unchanged, tradition is not synonymous with archaisms or retrograde"2. In the context of innovation, emphasizes the researcher, the interaction of tradition and innovation is transformed into a constructive dialogue, forming an innovative culture. In this context, the contemporary choreographer is seen as the subject of innovative processes, in the professional activity of which the dialogue of tradition and innovation "is the basis for the search for new forms and contents in the contemporary cultural and artistic space"3. As a successful example of innovation, K. Kyrylenko cites the contemporary dance that emerged at the beginning of the $21^{\text {st }}$ century as a synthesis of modern and postmodern dance with various techniques of oriental physical education schools (yoga, aikido, etc.). In our opinion, no less successful example of an innovative approach on the basis of Ukrainian culture is the creation of "Fighting Hopak" is a kind of reading of the iconic folk dance as a dance of the modern, and at the same time is as encrypted in its movements of a holistic system of psychophysical improvement created by the Zaporozhye Cossacks. "Fighting Hopak" was created in the late 1980s and became widely known among the Ukrainian youth, its recognition in the status of modern dance is confirmed by the authoritative opinion of M. Vantukh ${ }^{4}$.

Centuries-old traditions of Ukrainian folk choreography are distinguished by regional and local originality: the dances of the steppes differ from the dances of Polishchuk and Gorjan, even in the swords of one region, for example, the Carpathian, the dances of Hutsuls, fights and lemmas have distinct differences. However, throughout the variety of dance forms, Ukrainian choreography developed on the basis of common archetypes, a single macro-cultural code, and the principle of unity in diversity, which defined the role of folk dance as a powerful means of establishing Ukrainian identity. Understanding this role of folk dance is growing in the professionals minds and the general public after the Revolution of Dignity, in view of the circumstances of the "hybrid war", whose purpose in spiritual and cultural aspect is to eliminate identity. In today's struggle for Ukrainian dance, in

2 Kyrylenko, K.M. (2016). Tradytsii ta novatsii yak skladova innovatsiinoi kultury maibutnoho khoreohrafa. In Khoreohrafiia XXI stolittia: mystetskyi ta osvitnii potentsial: materialy Vseukrainskoi naukovo-praktychnoi konferentsii (m. Kyiv, 15-16 kvitnia 2016 r.). Kyiv: KNUKiM (pp. 17-20).

${ }^{3}$ Ibid.

${ }^{4}$ Burkovskyi, O. (2013). Zavzhdy v dorozi: Dokumentalna povist pro M. Vantukha. Kyiv: Presa Plius. 
addition to the challenges posed, new challenges are emerging that require theoretical reflection and an adequate and timely response from society.

\section{Topical issues of choreographic thought}

The culture of Ukraine, the territory of which for many centuries was divided between different states, developed under unfavorable conditions, under the influence of dominant cultures. This led, in particular, to the delayed, in comparison with other European peoples, the formation of scientific reflection on Ukrainian folk dance as an object of special research. The records of choreographic folklore made in the 19th - early 20th centuries by V. Hnatyuk, B. Grinchenko, P. Chubinsky, P. Shcheryk-Donykiv, B. Shukhevych, Polish ethnologist V. Shukhevych had mostly fragmentary characters, as were records of folk folklore, as well as records of folk folklore. The first "Theory of Ukrainian Folk Dance" by V. Verkhovynts appeared only in $1920^{5}$. The systematic development of Ukrainian choreographic art criticism in the Soviet era was significantly hampered by numerous restrictions and prohibitions. Its works were taken by K. Balog, M. Vantukh, K. Vasylenko, V. Verkhovynets, P. Virsky, O. Gomon, A. Gumenyuk, B. Kolnohuzenko, A. Krivokhizhi. Notable phenomenon was the publication of K. Vasylenko's fundamental work "The Lexicon of Ukrainian Folk Dances", which had no analogues in Soviet art criticism. It first substantiated a number of theoretical and methodological problems that are important for the development of national folk-stage choreography.

The main task of post-Soviet Ukrainian choreology was to critically rethink the theoretical framework created by its predecessors from the standpoint of historicism and scientific objectivity, using the latest methodological approaches. In general, the directions of modern chorological studies ${ }^{6}$ have been identified, which in a new way reveal the historical, cultural, theoretical, methodological and pedagogical aspects of the formation and Ukrainian folk development and folk choreography. The filling process the "white spots" is ongoing, that is, the return to scientific circulation of works removed from ideological considerations, biographical materials about prominent figures of national culture whose names were banned in Soviet times are published. Choreology is becoming an increasingly important component of national

${ }^{5}$ Verkhovynets, V. (1990). Teoriia ukrainskoho narodnoho tantsiu: 5-te vyd., dopovnene. Kyiv: Muzychna Ukraina.

${ }^{6}$ Kozynko, L.L. (2016). Zberezhennia folklornykh tantsiuvalnykh tradytsii u praktytsi profesiinykh khoreohrafichnykh kolektyviv zakhidnoho rehionu Ukrainy. In Khoreohrafiia XXI stolittia: mystetskyi ta osvitnii potentsial: materialy Vseukrainskoi naukovo-praktychnoi konferentsii, m. Kyiv, 15-16 kvitnia 2016 r. Kyiv: KNUKiM (pp. 62-67). 
culture, actively interacting with related fields of humanitarian knowledge and history, philosophy, cultural studies, ethnology, sociology.

Particular attention is paid by modern researchers to the study of authentic dance, the comprehension of figurative archetypes, regional cultural codes, zonal and local specificity of performance, and the influence of assimilation processes. Common terms are constantly being refined and new terms are introduced, which contributes to the achievement of terminological purity, the harmonization of scientific instruments with those established in European choreology. Ukrainian scientists use the foreign choreologists achievements. Thus, I. Mostova emphasizes, in particular, the productivity of using the experience of Polish choreologists to identify folk dances of Slobozhanshchina: "Based on the analysis of Polish scientists conceptualized the term "dance canon" to determine the dancing traditions features of Slobozhanshchina"7. The researcher states: "The term "dance canon" defines a system of folk dance signs, which allows identifying deep meanings and symbols during their broadcast and, forming one system, identifies dance with a nation, ethnographic group, and region", .

The concept of identifying dance with a nation, region, ethnographic group, etc. is at the heart of the vast majority in current research. Unlike Soviet art critics, who, by carefully examining the early forms of folk dance, relayed tendencies about the "common origins" of Russian, Ukrainian, and Belarussian dance, Ukrainian scholars, drawing on the experience of prominent national historians of the past (D. Antonovich, D. Bagaliy, F. Vovk, M. Hrushevsky, M. Maksimovich, V. Petrov, M. Sumtsov, I. Franko, D. Yavornitsky), the position and conclusions of modern historians, cultural scientists, ethnologists (I. Dzyuba, V. Borysenko, M. Grimich, O. Kurochkina, A. Ponomaryov, G. Skrypnyk, V. Smolia, M. Popovych, $\mathrm{N}$. Yakovenko), the achievements of world humanitarian studies reproduce the real picture of the evolution of folk choreographic culture.

V. Shkorinenko emphasized the need to understand the phenomena of folk and folk-choreography in a wide cultural context, one of the first in the Ukrainian post-Soviet choreology, recognizing as a primary task "the definition of approaches that would allow to conceptually justifying the traditional and the context of national and human culture" . Noting that onesidedness in the analysis of artistic forms of dance has caused a number of problems with its identification, B. Shkorinenko looks for the key to solving

${ }^{7}$ Mostova, I.S. (2019). Khudozhno-mystetski aspekty identyfikatsii narodnykh tantsiv Slobozhanshchyny v konteksti sotsiokulturnoho rozvytku rehionu. PhD Thesis. Kharkiv, p. 6.

${ }^{8}$ Ibid.

${ }^{9}$ Shkorinenko, V.O. (2003). Narodnyi tanets u tradytsiinii i suchasnii kulturi Ukrainy. PhD Thesis. Kyiv, p. 6. 
them in the methodological plane: "The most promising area is the rethinking and the systematization of research material from a cultural standpoint", the researcher says, - that is, the consideration of the dance art as an integral part of the overall process of ethno culture" 10 .

The methodological "retooling" process of Ukrainian choreology is ongoing. Its performance is evidenced by the research of O. Yelyokhina, K. Kinder, A. Korol, N. Marusyk, O. Merlianova, A. Morozov, I. Mostova. Thus, the use of the poly methodology principle, the phenomena comprehension of folk and folk-choreography at the junctions of different branches of humanitarian knowledge is choreology, philosophers, history, cultural studies, sociology, ethnology, ethno-psychology, religious education, theatrical education and music, peculiarities positions of dance art of Kyven Russ, in particular, dance art of buffoons ${ }^{11}$; K. Kinder is to reveal the semantics of plastic symbols of folk dance ${ }^{12}$; A. King is to interpret female characters in Ukrainian ballets in a new way, using the experience of modern ethno-choreology ${ }^{13}$; A. Morozov is to study the evolution of virtuoso movements in folk and folk-dance ${ }^{14}$. The principle of poly methodology was used by us to clarify a number of the theory provisions of artistic image, the basis of which is not always consistently substantiated and formulated by K. Vasylenko.

The mentioned and other works of young Ukrainian researchers, as well as numerous analytical articles and explorations published in scientific periodicals, materials of scientific and practical conferences, etc. testify to the qualitative growth of modern Ukrainian choreology. At the same time, we have to state that the process of accumulating material in Ukraine, which should be completed with the creation of generalizing works on the history of folk choreographic art, is somewhat delayed. In the sphere of theoretical, methodological and pedagogical literature, which in the days of independence was enriched by the works of K. Vasylenko, O. Zharov, S. Zabredovsky, S. Zubatov, A. Markovich, A. Tarakanova, O. Tarantseva, the lack of generalizing works of textbook character is keenly felt. Actually, whether or not there is only systematic

${ }^{10}$ Shkorinenko, V.O. (2003). Narodnyi tanets u tradytsiinii i suchasnii kulturi Ukrainy. PhD Thesis. Kyiv, p. 6.

${ }^{11}$ Yelyokhina, O.O. (1996). Problemy rozvytku tantsiuvalnoho mystetstva Ukrainy. Period Kyivskoi Rusi. PhD Thesis. Kyiv.

${ }^{12}$ Kinder, K.R. (2007). Semantyka plastychnykh symvoliv narodnoi tantsiuvalnoi kultury ukraintsiv. PhD Thesis. Kyiv.

13 Korol, A.M. (2019). Zhinochi obrazy v ukrainskykh baletakh. PhD Thesis. Kyiv: KNUKiM.

${ }^{14}$ Morozov, A.I. (2019). Virtuozni rukhy v ukrainskomu narodno- stsenichnomu tantsi. PhD Thesis. Kyiv: KNUKiM. 
textbook is "Ukrainian Dance" by K. Vasylenko", certain provisions and conclusions of which, formed under the Soviet art criticism influence, need correction. A productive attempt to create a textbook on the material of a particular region for students of specialized educational institutions of the first year study is the "methodology of teaching Ukrainian folk dance" by S. Zubatov ${ }^{16}$. However, manuals of this type, to some extent satisfying the demand, given the narrow coverage of the material, cannot compensate for the lack of generic, universal textbooks on folk choreographic art. Creating such author's or collective textbooks is a top priority for Ukrainian scientists.

The worst, in our opinion, is the case of literature addressed to the mass reader, whose purpose is to popularize Ukrainian dance, in accessible narratives to reveal to the general public its aesthetic perfection, ancient history, significance in the past and present life of the people. After all, mass consumers of different types of contemporary cultural product are unlikely to be interested in repertoire collections, theoretical and methodological developments, dissertations, articles in specialized collections, which are out of print and addressed to specialists, as well as anniversary presentations such as, for example, "Bukovina dance" ${ }^{17}$. Mass reader needs vivid stories about dances, documentary stories about outstanding choreographers and dancers. In our opinion, a positive example of such literature needed by society is O. Burkovsky's already mentioned story "Always on the Road" ${ }^{\text {" }}$. The text is a record of M. Vantukh's memoirs and reflections. The book is read with unwavering interest because it reveals the master's creative laboratory, contains emotionally charged thoughts, addressed not only to professionals but also to Ukrainian society. Unfortunately, we have very few such books, and they are badly needed. In the competition against mass culture, we are still losing in such an important segment as the popularization of folk choreographic art by means of literature.

\section{Questions of interaction of folk-stage and household dancing}

Ukraine is rightly proud of the outstanding choreographers' achievements and performers of folk-dance, whose list is headed by P. Virsky. Building his own artistic style based on the synthesis of folk dance and classical ballet, P. Virsky created choreographic masterpieces that are admired not only in Ukraine but also

\footnotetext{
${ }^{15}$ Vasylenko, K. (1997). Ukrainskyi tanets: pidruchnyk. Kyiv : IPKPK.

${ }^{16}$ Zubatov, S.L. (2017). Metodyka vykladannia ukrainskoho narodnoho antsiu: pidruchnyk. Kyvi: Lira.

17 Bukovynskyi tanets u zapysakh M. A. Pomorenskoho, Ya. P. Murakhovskoho, T.V. Suliatyzhkoho, M. H. Pupchenka. (2007). Chernivtsi: Vydavnychyi dim "Bukrek".

${ }^{18}$ Burkovskyi, O. (2013). Zavzhdy v dorozi: Dokumentalna povist pro M. Vantukha. Kyiv: Presa Plius.
} 
in many countries of the world, as evidenced by numerous reviews in the foreign press, given by the author of the article cited. M. Vantukh, who headed the P. Virsky Dance Ensemble after the master's death, has set himself the goal of preserving his classic heritage and creating, based on the aesthetic potential of these and those inheriting P. Virsky's traditions.

The cultural policy of the Soviet authorities consisted in the network development of professional and amateur ensembles of various levels, whose repertoire was tightly controlled, with the simultaneous consistent eradication of authentic folk dance as an important component of national custom in folk life and the replacement of its forms with surrogate innovations. The result of this cultural policy was, on the one hand, the achievement of a high level of dance skill in professional teams headed by K. Balogh, M. Vantukh, V. Verkhovynets, P. Virsky, O. Homon, L. Kalinin, O. Kolosk, A. Krivokhizha, D. Swallow, V. Marushchak, V. Mikhailov, Y. Chuperchuk the second is the decline of folk dance culture in the context of the general decline of folklore traditions that tried to replace them with false Soviet "traditions" in the format of "red calendar", "Komsomol wedding", etc. Mass folk dance was better preserved in Western Ukrainian lands, finally annexed to Soviet Ukraine after World War II, where assimilation processes and earlier historical periods were marked by lower dynamics than in the territory of "sub-Russian" Ukraine.

As of the early 2000s, a wide network of professional and amateur choreographic teams was operating in Ukraine: National Dance Ensemble named after P. Virsky (Kyiv), "Tavriya" (Simferopol), "Donbass" (Donetsk), "Nadzbruchanka" (Ternopil), "Zoryani" (Kirovohrad, now Kropyvnytskyi), "Slavuta" (Dnipropetrovsk, now - Dnipro), Verkhovyna (Lviv), Rodoslav (Zhytomyr), highly professional choreographic groups of the People's Choir named after G. Verevka, Transcarpathian, Volyn, Cherkasy folk choirs, Bukovyna, Chernihiv, Hutsul ensembles of songs and dances, Poltavskaya also about 20 thousand choreographic groups of different departments ${ }^{19}$.

In the past, the network of choreographic groups has undergone some changes. The Ukrainian choreographic groups in the annexed by the Russian Federation of Crimea and in the areas occupied by Donetsk and Lugansk regions ceased their activity; in new economic and socio-cultural circumstances, a number of ensembles were on the verge of survival, and some ceased operations.

In order to preserve national choreographic culture, develop performing traditions and popularize Ukrainian dance in new cultural realities at the

${ }^{19}$ Stan narodnoi khoreohrafii v Ukraini ta perspektyvy yii rozvytku: materialy naukovopraktychnoi konferentsii (28 liutoho 2002 r., m. Kyiv). (2002). Kyiv: Stylos, p. 5. 
initiative of leading masters, in 2002 an All-Ukrainian Choreographic Union was founded, headed by M. Vantukh, and the All-Ukrainian Festival of Folk Choreography was founded. These activities soon proved to be effective, but they are not enough for radical changes in the field of folk choreographic art, which, unlike contemporary choreography, which is actively developing in the context of show business, requires state care and material support. Independent Ukraine is defined by lack of clarity and weakness. "Unfortunately, we do not have a state policy in the field of culture and art", says M. Vantuh. - Everything is tossed, everyone does what they want. And this is under the slogan "We are going to Europe!" And will it not happen that while we run there, we will lose everything?"20

The process of national-cultural revival in Ukraine, for all its positives, turned out to be extremely dramatic. In the context of the traumatic breakdown of the old system of cultural management and the formation of fundamentally new forms of organization of cultural and artistic process and change of social priorities before the national choreography posed a real threat to be on the cultural periphery.

Leading oligarch-funded TV channels are removing folklore and folkdance from their programs, favoring contemporary choreography. "The passion for rhythm mania drove the folk dance from the repertoire of most amateur groups," - said A. Krivozhikha ${ }^{21}$. According to D. Demkiv, one of the most pressing issues of choreographic art was the "uncontrolled travel abroad of all kinds of concerts under the brand of "dance ensembles", which degraded the Ukrainian culture, glorified in the world thanks to the activities of the collectives named after P. Virsky, G. Veryovka and others ${ }^{22}$. A number of problems in professional preparation of students are noted by S. Zabredovsky, in particular:

" - One-sidedness of scientific-theoretical, professional knowledge, lack of their completeness in the field of Ukrainian folk choreographic art ;

- insufficient level of general geographical practical skills and skills for the fulfillment of future multifaceted artistic, creative and pedagogical activity;

${ }^{20}$ Burkovskyi, O. (2013). Zavzhdy v dorozi: Dokumentalna povist pro M. Vantukha. Kyiv: Presa Plius. p. 24.

${ }^{21}$ Kryvokhyzha, A.M. (2002). Problemy narodno-stsenichnoi khoreohrafii ta shliakhy yikh vyrishennia. In Stan narodnoi khoreohrafii v Ukraini ta perspektyvy yii rozvytku: materialy naukovo-praktychnoi konferentsii (28 liutoho 2002 r., m. Kyiv). Kyiv: Stylos (pp. 62-64).

${ }^{22}$ Demkiv, D.P. (2002). Problemy ta rozvytok ukrainskoi narodnoi khoreohrafii. In Stan narodnoi khoreohrafii $v$ Ukraini ta perspektyvy yii rozvytku: materialy naukovo-praktychnoi konferentsii (28 liutoho 2002 r., m. Kyiv). Kyiv: Stylos (pp. 42-43). 
- a narrow understanding of the content and nature of the functioning of folk choreographic art ..."23.

S. Zabredovsky emphasizes that the main factor of professional preparation of students is the motivational sphere, that is, a conscious choice of activity, which provides an asceticism element.

These and other problems, formulated by the participants of the stage in the recent history of Ukrainian dance of the conference "State of folk choreographic art in Ukraine and prospects for its development", have not lost their relevance today. The positive changes that have taken place since the conference (2002) mainly concerned the sphere of folk-dance and the use of Ukrainian dance in contemporary domestic culture is of concern. Understanding this problem and finding ways to solve it by harmonizing the two spheres: folk and stage dancing, given the rapid dynamics of urbanization processes and the onset of mass culture is a priority of the scientific environment, a society at large, building a European future that is bound by the obligation of the maintaining cultural values.

As you know, folk dance was formed in the context of national holidays of calendar and family cycles, the whole complex of traditional custom. Its functioning is ensured by the preservation of traditional culture elements in a particular region. Huge arrays of folk dances are associated with calendar holidays (spring dance); dance games related to the Kupala and New Year and Christmas holidays, ceremonial wedding dances (ceremonial and erotic). The names of the Bukovynian dances "In Chunkov at the temple" (Rzhavintsev village), "Wreath of Bukovyna dances in Toloka" (Mamaivtsi village), "At the Banylivka crowd" (Banylovo village), "Levenets temple festivals" (Leventsiv village) attest to their tethering not only to a particular locality, but also to certain work and religious traditions, marked by local identity ${ }^{24}$.

A valuable contribution to the treasury of national culture was made by Ukrainian choreographers, recording and re-enacting a large number of authentic dances, providing them with a long stage life. Field studies were carried out by V. Avramenko, K. Balogh, K. Vasylenko, V. Verkhovynets, P. Virsky, A. Krivokhizha, D. Lastovka, Y. Murakhovsky, M. Pomoryansky, and Y. Chuperchuk. In particular, K. Balog recorded and staged such Transcarpathian dances, such as "Rakovetsky twisted", "Chotyryanka",

${ }^{23}$ Zabredovskyi, S.H. (2002). Rozvytok motyvatsiinoi sfery studentiv - yak zaporuka pidvyshchennia yakosti navchannia. In Stan narodnoi khoreohrafii v Ukraini ta perspektyvy yii rozvytku: materialy naukovo-praktychnoi konferentsii (28 liutoho 2002 r., m. Kyiv). Kyiv: Stylos (pp. 31-36).

24 Bukovynskyi tanets u zapysakh M. A. Pomorenskoho, Ya. P. Murakhovskoho, T.V. Suliatyzhkoho, M. H. Pupchenka. (2007). Chernivtsi: Vydavnychyi dim "Bukrek", p. 25. 
"Fighting fun" (from the Irshava district), "Sheepdogs on Polonina" (Rakhiv district), "Droboyka" (Mizhhirsky district), Bereznyanka (Veliko Bereznyany district) ${ }^{25}$. More than 30 dances of Zaporizhzhya region recorded Z. Sizonenko ${ }^{26}$. This list can be continued for a very long time as evidence of the ascension of Ukrainian choreographers in the Soviet period of history. However, it should be remembered that at that time the process of preserving choreographic authenticity was carried out mainly in one direction and from the folk environment to the amateur or professional scene, since folklore, including choreographic, customs and rituals were more or less eradicated from the folk. Today, special attention is needed to ensure the movement in the opposite direction, that is, the relaying of Ukrainian folk dance from the stage to the national environment, hence its revival in the context of the general process of revival of traditions. The dynamics of this process in the aspect of choreography is still far behind the dynamics of the revival of the folk song treasures and let us remember at least the proliferation of Christmas carols in Ukraine today, which were recently banned by the totalitarian state.

\section{An image of Ukrainian dance in the media space}

Writing about the Ukrainian folk dance, researchers do not tire of repeating that it is a unique property of the spiritual culture of the nation and self-identification means, reflects the character of the people and its inherent features: cheerfulness, soft humor, lyricism, etc. All this is true, although the stereotypical formulations of the "love-loving nature", "the reflection of the struggle heroics and the grandeur of victories and the joy of creative work" that have transposed into modern texts from Soviet art, together with the stamp "sparkling dance", have long filled the rubble. All this is true, although the stereotypical formulations of the "love-loving nature", "the reflection of the struggle heroics and the grandeur of victories and the joy of creative work" that have transposed into modern texts from Soviet art, together with the stamp "sparkling dance", have long filled the rubble. Unfortunately, this is not how Ukrainian folk dance appears in the contemporary media space, in particular, in various musicals, TV shows, and kitsch.

During the breaking of the stereotypes of Soviet culture, the folk choreographic art, unilaterally interpreted individually in the context of the populist tradition of the nineteenth and early twentieth centuries, suffered from biased and sometimes destructive criticism, a continuation of which, in

25 Baloh, K.F. (2008). Tantsi Zakarpattia: Repertuarnyi zbirnyk. Uzhhorod: KP "Uzhhorodska miska drukarnia", p. 5.

${ }^{26}$ Chmil, V.A. (2005). Tantsi Zaporizkoho kraiu v obrobtsi Z. Syzonenka. Kyiv: Vydavnychyi budynok "MMD". 
particular, O. Raznik sees in the choreographic art of "socialist realism". Evaluating the activities of "similar to each other, as if water drops of amateur dance or "songs and dance" "ensembles", as well as a "network of "exemplary" professional choreographic collectives, which should not only show the flowering of national cultures in the USSR, but also indicate their own citizens, what and how the "Soviet man" should dance ${ }^{27}$, the cultural scientist did not mention the artistic achievements of the choreographic collectives. In his opinion, they were only "powerful amplifiers" of the hinged-embroidered stereotype of the Ukrainian.

Defending the idea of creating a modern nation, some researchers believe; that showing on the TV screen of diverse folklore activities accompanied by authentic dances, concerts by well-known choreographic groups (such TV projects were a characteristic phenomenon of the 1990s) draws Ukrainians into the patriarchal past. Folk dances are interpreted by cultural scientists of the postmodernist orientation as a surviving instrument of Ukrainian based on the classical literature models of the XIX - beginning of the XX centuries, as a return to the "sharovarshchina", which should be eliminated. However, according to L. Novikov, "the masses did not want to identify themselves with the proposed image of Ukraine and Ukrainians" 28 .

The critique of folklore activities in the media space contributed to the fact that in the early 2000s the folk dance disappeared from the screen of Ukrainian television, giving way to mass culture products. This phenomenon alarmed the choreographic community. Appealing to TV producers, Yu. Gureyev notes: "It would be desirable for them not to be scared of accusations of "hawksbill" (very often this term is used badly and intentionally to humiliate and destroy our culture) and would organize a series of educational programs for children (and not only!) ... and show (they were very bored!) broadcasts (at least from stock materials) with performances by the best professional groups, as well as song and dance ensembles and folk choirs where there is a dance group. "This would be a real contribution to the continuation of the cause for which the bright and light life of P. Virsky lived"29. The disappearance of Ukrainian folk dance from the TV screen is noted with alarm by D. Demkiv: "... Ukrainian television favors contemporary dance, variety sports, ballroom and folk choreography. If we had

${ }^{27}$ Riznyk, O. (1998). Tanets. In Narysy ukrainskoi populiarnoi kultury. Kyiv: UTsKD, p. 647.

${ }^{28}$ Novykova, L. \& Trymbach, S. (1998). Telebachennia. In Narysy ukrainskoi populiarnoi kultury. Kyiv: UTsKD, p. 677.

${ }^{29}$ Hureiv, Yu.I. (2002). Vykhovannia natsionalnoi svidomosti zasobamy khoreohrafii v dytiachomu samodiialnomu kolektyvi. In Stan narodnoi khoreohrafii v Ukraini ta perspektyvy yii rozvytku: materialy naukovo-praktychnoi konferentsii (28 liutoho 2002 r., m. Kyiv). Kyiv: Stylos, p. 96. 
previously had the opportunity to study television ... to study in the glorious ensembles of P. Virsky, G. Verevka choir, now there are no such programs" ${ }^{\text {30 }}$.

The quotes we have received are from the conference materials almost twenty years ago. Has the situation improved today? We are confident that it has not improved. "I am already sick of the so-called modern dance that has filled all television screens," admits M. Vantukh. - "Because what we see is not dance, it's show business, far from art and dance" 31 . Appreciating in general the interest of contemporary youth in dance, M. Vantukh notes onesidedness and at the same time points to the narrowness of this interest, which is formed by the television screen: "Today you can learn a lot about modern dances and watch them without leaving home, in numerous television projects: "Dancing everyone!", "Dancing with the stars", "Big dances", "Maidans", "Dirty dances". There is even a dance and social project "Free man is free land" ${ }^{32}$. The outstanding choreographer questions the aesthetic value of the choreographic television projects offered to the viewer: "In ballet, on stage, in television programs, you can make any production, but first of all, one should think about its moral and aesthetic component, remember the great influence of art on people, rather than spoiling the youth with a low-key spectacle, calling it a modern dance ${ }^{33}$.

In the context of the problem of the presentation of Ukrainian folk choreography in television programs, it should be clarified: dancing as a phenomenon of national culture disappeared, giving way to a parody image of Ukrainian folk dance in satirical programs, kitsch, etc. Observing individual kitschy on the TV screen with the use of elements of dance moves and national clothing, it is sometimes difficult to set the slippery boundary beyond which irony or satire turns into a vicious mockery of national culture when a Ukrainian is presented in the image of a misunderstood "little-haired" or "layered", who thoughtlessly has fun in "vodka-hopak" Ukraine. Unfortunately, researchers who have an inadequate understanding of the Ukrainian dance history, its role and significance in national culture, tend to perceive, treat abusive caricatures of dance as manifestations of postmodern irony. We analyzed this negative trend in one of the author's articles ${ }^{34}$, in particular, pointing out that the authors and

${ }^{30}$ Demkiv, D.P. (2002). Problemy ta rozvytok ukrainskoi narodnoi khoreohrafii. In Stan narodnoi khoreohrafii $v$ Ukraini ta perspektyvy yii rozvytku: materialy naukovo-praktychnoi konferentsii (28 liutoho 2002 r., m. Kyiv). Kyiv: Stylos, p. 43.

${ }^{31}$ Burkovskyi, O. (2013). Zavzhdy v dorozi: Dokumentalna povist pro M. Vantukha. Kyiv: Presa Plius.

${ }^{32}$ Ibid.

${ }^{33}$ Ibid.

${ }^{34}$ Boiko, O.S. (2017). Ukrainskyi narodnyi tanen u komediinykh teleshou: ironichna interpretatsiia chy vulharyzatsiia? Ukrainian Culture: the Past, Modern, Ways of Development, 24, 291-296. 
perpetrators of evil parodies are not so much in the "wildlife" as in the Ukrainian dance in general, consciously or unconsciously continuing the dubious tradition formed in the Russian Empire and fueled by the enemies of Ukraine today as one of the "hybrids".

Lexical "arsenal" we attribute parody dances as a "dance doublespeak" 35 . The use of such rust, as well as linguistic, can be justified in view of the artistic purpose of ridiculing certain rudiments of everyday culture. However, if in entertaining TV shows we see Ukrainian folk dance only in a caricatured, distorted way, then, given the lack of programs in the TV show presenting high artistic achievements of national choreographic art, it makes one speak of a dangerous trend. Considering the popularity of numerous show projects is "Quarter 95" on $1+1$ channel, "Diesel show" on ICTV, the Russian show, the hopes for radical shifts in the media space appear rather illusory. At least for now it should be noted that the vocabulary of Ukrainian folk dance has partly become today the material for the creation of a show-product of a cat character, such as the image of Verka Serdyuchka ${ }^{36}$.

\section{CONCLUSIONS}

Ukrainian folk-choreography is actively reforming in the context of creating a model of modern national culture, preserving and developing the artistic heritage of the past and responding to the present challenges. The introduction into the scientific circulation of significant arrays of factual material, the critical rethinking of the theoretical base developed by its predecessors, and the use of modern research methods have ensured the qualitative growth of Ukrainian chorological thought. The biggest problems of choreology include the problem of creating a generalized history of folk choreographic art and complex modern textbooks on choreography. Sharply lacking books addressed to the mass reader that would promote dance as a unique phenomenon of national culture, reveal its incorruptible aesthetic value and significance as a powerful means of asserting Ukrainian identity.

Even in difficult circumstances of political, economic and cultural crisis, professional and amateur groups are steadily growing creatively and present the best samples of folk-dance in Ukraine and abroad. Among the priorities of the choreographers are the problems of clearing the choreographic art from the rudiments of "socialist realism", as well as the creation of effective

35 Boiko, O.S. (2017). Ukrainskyi narodnyi tanen u komediinykh teleshou: ironichna interpretatsiia chy vulharyzatsiia? Ukrainian Culture: the Past, Modern, Ways of Development, 24, 291-296.

${ }^{36}$ Hrytsenko, O. (1998). Vierka Serdiuchka yak dzerkalo ukrainskoi kulturnoi transformatsii. In Heroi ta znamenytosti v ukrainskoi kultury. Kyiv: UTsKD (pp. 340-351). 
mechanisms of protection against the negative impact of globalization processes, counteracting the expansion of Russian culture in the context of "hybrid war".

Today one of the major challenges is the problem of popularizing folk dance in the media space. While Ukrainian folk-dance and folklore dance has virtually disappeared from television screens, numerous show projects offer the mass spectator often doubtful about the aesthetic dimension of contemporary choreography.

The dangerous tendency of today has been the use of elements of folk dance in satirical television projects that form an inadequate view not only of dance, but also of the national culture of Ukrainians.

\section{SUMMARY}

The section on extensive material highlights the overall picture of the transformation of folk choreographic art in Independent Ukraine. In particular, attention is paid to topical issues of choreographic thought, as well as issues of interaction of folk-stage and everyday dance. The image of Ukrainian dance in the media space is revealed in the light of the trends that determine the life of Ukrainian dance in modern society. Priorities in choreography and practical activity of choreographers have been outlined and priorities have been highlighted: problems of creating modern textbooks on choreography, popularization of values of folk dance art in literature and mass media, revival of Ukrainian dance not only on stage, but also in folk life. As one of the negative tendencies characteristic of the contemporary cultural and artistic process, the widespread practice of using mock (using the brand of ironic) use of folk dance vocabulary in satirical TV projects, kitsch has been analyzed.

\section{REFERENCES}

1. Baloh, K.F. (2008). Tantsi Zakarpattia: Repertuarnyi zbirnyk. Uzhhorod: KP "Uzhhorodska miska drukarnia".

2. Boiko, O.S. (2017). Ukrainskyi narodnyi tanen u komediinykh teleshou: ironichna interpretatsiia chy vulharyzatsiia? Ukrainian Culture: the Past, Modern, Ways of Development, 24, 291-296.

3. Bukovynskyi tanets u zapysakh M.A. Pomorenskoho, Ya. P. Murakhovskoho, T. V. Suliatyzhkoho, M. H. Pupchenka. (2007). Chernivtsi: Vydavnychyi dim "Bukrek".

4. Burkovskyi, O. (2013). Zavzhdy v dorozi: Dokumentalna povist pro M. Vantukha. Kyiv: Presa Plius.

5. Vasylenko, K. (1997). Ukrainskyi tanets: pidruchnyk. Kyiv : IPKPK.

6. Verkhovynets, V. (1990). Teoriia ukrainskoho narodnoho tantsiu: 5-te vyd., dopovnene. Kyiv: Muzychna Ukraina. 
7. Hrytsenko, O. (1998). Vierka Serdiuchka yak dzerkalo ukrainskoi kulturnoi transformatsii. In Heroi ta znamenytosti v ukrainskoi kultury. Kyiv: UTsKD (pp. 340-351).

8. Hureiv, Yu.I. (2002). Vykhovannia natsionalnoi svidomosti zasobamy khoreohrafii v dytiachomu samodiialnomu kolektyvi. In Stan narodnoi khoreohrafii $v$ Ukraini ta perspektyvy yii rozvytku: materialy naukovopraktychnoi konferentsii (28 liutoho 2002 r., m. Kyiv). Kyiv: Stylos (pp. 91-96).

9. Demkiv, D.P. (2002). Problemy ta rozvytok ukrainskoi narodnoi khoreohrafii. In Stan narodnoi khoreohrafii $v$ Ukraini ta perspektyvy yii rozvytku: materialy naukovo-praktychnoi konferentsii (28 liutoho 2002 r., m. Kyiv). Kyiv: Stylos (pp. 42-43).

10. Yelyokhina, O.O. (1996). Problemy rozvytku tantsiuvalnoho mystetstva Ukrainy. Period Kyivskoi Rusi. PhD Thesis. Kyiv.

11.Zabredovskyi, S.H. (2002). Rozvytok motyvatsiinoi sfery studentiv yak zaporuka pidvyshchennia yakosti navchannia. In Stan narodnoi khoreohrafii $v$ Ukraini ta perspektyvy yii rozvytku: materialy naukovopraktychnoi konferentsii (28 liutoho 2002 r., m. Kyiv). Kyiv: Stylos (pp. 31-36).

12.Zubatov, S.L. (2017). Metodyka vykladannia ukrainskoho narodnoho antsiu: pidruchnyk. Kyvi: Lira.

13. Kyrylenko, K.M. (2016). Tradytsii ta novatsii yak skladova innovatsiinoi kultury maibutnoho khoreohrafa. In Khoreohrafiia XXI stolittia: mystetskyi ta osvitnii potentsial: materialy Vseukrainskoi naukovopraktychnoi konferentsii (m. Kyiv, 15-16 kvitnia 2016 r.). Kyiv: KNUKiM (pp. 17-20).

14. Kinder, K.R. (2007). Semantyka plastychnykh symvoliv narodnoi tantsiuvalnoi kultury ukraintsiv. PhD Thesis. Kyiv.

15. Kozynko, L.L. (2016). Zberezhennia folklornykh tantsiuvalnykh tradytsii u praktytsi profesiinykh khoreohrafichnykh kolektyviv zakhidnoho rehionu Ukrainy. In Khoreohrafiia XXI stolittia: mystetskyi ta osvitnii potentsial: materialy Vseukrainskoi naukovo-praktychnoi konferentsii, m. Kyiv, 15-16 kvitnia 2016 r. Kyiv: KNUKiM (pp. 62-67).

16. Korol, A.M. (2019). Zhinochi obrazy v ukrainskykh baletakh. PhD Thesis. Kyiv: KNUKiM.

17. Kryvokhyzha, A.M. (2002). Problemy narodno-stsenichnoi khoreohrafii ta shliakhy yikh vyrishennia. In Stan narodnoi khoreohrafii $v$ Ukraini ta perspektyvy yii rozvytku: materialy naukovo-praktychnoi konferentsii (28 liutoho 2002 r., m. Kyiv). Kyiv: Stylos (pp. 62-64).

18. Morozov, A.I. (2019). Virtuozni rukhy v ukrainskomu narodnostsenichnomu tantsi. PhD Thesis. Kyiv: KNUKiM. 
19. Mostova, I.S. (2019). Khudozhno-mystetski aspekty identyfikatsii narodnykh tantsiv Slobozhanshchyny v konteksti sotsiokulturnoho rozvytku rehionu. PhD Thesis. Kharkiv.

20. Novykova, L. \& Trymbach, S. (1998). Telebachennia. In Narysy ukrainskoi populiarnoi kultury. Kyiv : UTsKD (pp. 667-686).

21. Riznyk, O. (1998). Tanets. In Narysy ukrainskoi populiarnoi kultury. Kyiv: UTsKD (pp. 645-654).

22. Skrypnyk, H.A. (2008). Istoriia ukrainskoi kultury: u 5 tomakh. T. 4. Kn. 1. Kyiv: Naukova dumka.

23. Stan narodnoi khoreohrafii $\mathrm{v}$ Ukraini ta perspektyvy yii rozvytku: materialy naukovo-praktychnoi konferentsii (28 liutoho 2002 r., m. Kyiv). (2002). Kyiv: Stylos.

24. Chmil, V.A. (2005). Tantsi Zaporizkoho kraiu v obrobtsi Z. Syzonenka. Kyiv: Vydavnychyi budynok "MMD”.

25. Shkorinenko, V.O. (2003). Narodnyi tanets u tradytsiinii i suchasnii kulturi Ukrainy. PhD Thesis. Kyiv.

\section{Information about the author:}

Olha Boiko,

Candidate of Arts, Associate Professor, Associate Professor of the Choreographic Art Department, Kyiv National University of Culture and Arts, 36, Y. Konovalets str., Kyiv, 01133, Ukraine http://orcid.org/0000-0001-4534-2201 


\section{MODERN MUSICOLOGY RESEARCH: GAME THEORY PROJECTIONS}

\section{Kateryna Fadyeyeva}

\section{INTRODUCTION}

In the history of the development of mathematical science, the theoreticalgame principles can be traced over a long period of time, which is measured over several centuries. The Game theory has numerous fields of application in those areas of knowledge where the condition of uncertainty, stochasticity is manifested. Extrapolation of the theoretical-game regularities to the study of composer's creativity allows us to find out the logical-constructive principles of musical thinking, associated with combinatorics and probability.

The relevance of the topic of the study is determined by the nature of contemporary composer's thinking, the updating of composer techniques, the searches and the combination of various sound-producing means in the context of the theoretical-probabilistic, random (stochastic) processes, with focusing attention on game regularities in mechanisms of musical thinking.

The purpose of the research is to study the manifestation of the theorygame regularities in the composer's creativity.

The analysis of the musical text in the projection of probability theory and the theory of games provides an opportunity to study logical-constructive regularities in composer's thinking.

The origins of the principles of the mathematical probability theory were first discovered on examples of gambling and games in dice that were found in archival documents of correspondence of B. Pascal and P. Fermat dated July 29,1654 . It is up to this date that the emergence of the theory of games as a mathematical discipline can be attributed. At the categorical level of scientific knowledge, the concept of "probability" reflects a special type of relationships between phenomena that characterize the processes indicated by the sign of multiplicity. In connection with the above, let us note that the theory of probability as a mathematical science reveals the regularities that arise in the interaction of a significant number of random factors in the form of a qualitatively peculiar connection between random and necessary. Based on the above theoretical-probabilistic definitions and regularities, it is important to note that apart from the various connections within the limits of mathematical probability the game theory has numerous applications outside of it, mainly in those branches of knowledge where is the condition of uncertainty is manifested. The theory of games was created by studies of 
Ch. Waldegrave (1712), D. Bernoulli (1732), P. Laplace (1814), J. Bertrand, E. Zermelo (1911), E. Borel (1921), J. Neumann (1928), O. Morgenstern.

Besides the various connections within Mathematics itself, the game theory has numerous applications beyond it, mainly in those areas of knowledge where uncertainly is encountered.

\section{Patterns of game theory in theoretical musicology. Analytical retrospections}

Game patterns in musicology are manifested in the folk polyphony. Thus, in J. Hominsky's study "The History of Harmony and counterpoint" it was noted that in the Ukrainian and Russian folklore the heterophonic kind if polyphony was most developed, characterized by simultaneous combinations of different variants of the same melody with vocal, instrumental or mixed performance. In the process of performance there is an element of spontaneity, which is caused by the creative capabilities of the performers, improvisation, integrated with the means of musical expression ${ }^{1}$.

Investigating the logical-constructive processes in composer's work it turned out to be important for us that the theoretical game regularities were used in the art science in the work of composer Ia. Xenakis "Formalized areas of music"2. Thus, in particular, in the third chapter, named "Musical Strategy", the principles of a musical composition, created by two groups of performers in accordance with the principles of the game theory, are set forth. The use of gaming factors allows us to generalize that this is a spontaneous, stochastic process, where each state determines the strategy of the game, which is conducted in accordance with the matrix of the transition.

In the composition of Ia. Xenakis "Strategy" for two orchestras the composer uses a game concept based on combinatorial principles. In this work the game situation is manifested in the duration and speed of combinatorial combinations.

The concept of the analysis of academic professional composer creativity, which is considered in connection with the system-structural method of analysis of composer's personality, is proposed by A. Mukha in the study "The Process of Composer's Creativity"3. The processuality of the artist's work is directed at the composition of the musical work which is determined by structural elements and dynamic development (from the initial to the final

\footnotetext{
${ }^{1}$ Hominsky, J. (1975, 1979). Istorija gharmoniji ta kontrapunktu. Kyiv: Muzychna Ukraina. (Vols. 1, 2).

${ }^{2}$ Xenakis, Ia. (1971). Formalized Music thought and mathematics in composition. London: Indiana University Press, Bloomington.

${ }^{3}$ Mukha, A.I. (1979). Protsess kompozitorskogo tvorchestva: problemy i puti issledovaniya. Kyiv: Muzychna Ukraina.
} 
stage). The most important, value component of the creative process is the process of choosing the appropriate option which arises spontaneously or improvisationally. Harmonious design of variants of a musical form depends on factors of the creative method, stylistic features, system of creative guides. A. Mukha applies theoretic-game regularities to the logical-constructive principles of musical thinking, focusing attention on rational moments in the creative process where the composer's individuality, figurative content, the system of representations, taking into account traditions and previous experience, are interrelated.

Ye. Nazaykinsky's study "The logic of musical composition" ${ }^{4}$ is devoted to the study of the laws and compositional principles of European professional instrumental music (on the example of the sonata-symphonic genre and instrumental miniature) in combination with the peculiarities of musical creativity, performing culture and perception of musical culture of the twentieth century.

In the context of our study, the fourth chapter of the above work, where the theoretical and game laws are considered, is of a particular interest. Thus, Ye. Nazaykinsky defines three main groups of functions that are characteristic of the composition of a work of art - a group of "communicative", a group of tectonic ("formative") and a group of meaningful and semantic functions. The most typical ones based on the general logic of development of the development material are dialogic and monological logic. The foresight offered by the musicologist explores the incorporation of game logic, which in the process of thematic development is determined by the laws of composition and reproduces it in intonation forms. Game logic uses one of the following forms - polylog, dialogue, monologue, or moves from one to the other. Analysis of instrumental works by D. Scarlatti, J. K. Bach, J. Haydn, W. A. Mozart, R. Schuman, F. Chopin, P. Tchaikovsky, S. Rachmaninov, I. Stravinsky demonstrated that game logic was not formed in the development, but in the initial sections of the form and integrated with the logic of exposure.

Structural aspect of the use of game-theoretical regularities is proposed by L. Akopyan in the article "Initial principles of formalized analysis of musical text" ${ }^{\text {"5 }}$. The author examines paradigmatic (a number of segments with repeating structures that are grouped into a certain number of paradigms) and syntactic (a unit of musical text, endowed with a more complex structure than

\footnotetext{
${ }^{4}$ Nazaykinsky, Ye.V. (1982). Logika muzykal'noy kompozitsii. Moscow: Musyka.

${ }^{5}$ Akopyan, L.O. (1986). Iskhodnye printsipy formalizovannogo analiza muzykal'nogo teksta. In Strukturnyy analiz teksta: sb. statey AN Armyanskoy SSR, 2. Yerevan: AN Armyanskoy SSR (pp. 210-220).
} 
a segment of the motive level), weak and strong positions of musical text, which are in the process of complex game.

\section{Patterns of game theory in the creativity of contemporary Ukrainian composers}

Analyzing modern studies that consider the inclusion of game regularities into the process of creating a musical composition, let us refer to the article by Alexei Skrypnyk "The phenomenon of aleatory in the work of composers of the twentieth century: the aesthetic and cultural aspect" $"$ where the trends of the development of musical art, which are associated with scientific achievements: the development of the universe as an evolving system, changes in the perceptions of the functioning of space and time, the macrocosm and the microcosm in the twentieth century, which influenced the character of the composer's thinking, are considered. According to the author of the article, the result of the above factors "... was a radical renewal of expressive means, techniques of composition aimed at reflecting the latest life impulses, events squeezed in time with their unusually high informative saturation, rapid dynamics of emotional and psychological processes" ${ }^{, 7}$.

O. Skrypnyk notes the most popular composer techniques: seriality, serial, sonoristics, micropolyphonia, pointillism and aleatory. In determining of the phenomenon of aleatory the author of the article gives a variety of areas of its interpretation in the works of musicologists - as a direction, method of composition, writing technique, directly musical composition, characteristics of the creative and performing process, provided by modern researchers P. Boulez, Ct. Kohoutek, E. Denisov, Yu. Kholopov, D. Shulgin, S. Pavlyshyn, L. Entelis, O. Sokolov, N. Gulianitskaya. The key principle of aleatory is "... the principle of randomness, which follows from the etymology of the term itself: "aleatory" from the Latin "alea" - a dice, lot, randomness"

The appearance of aleatory was associated with philosophical, culturological, social, psychological processes of the twentieth century ${ }^{9}$. The author of the article, considering the philosophical aspect of the problem of the origin and development of aleatory technique in the works of representatives of various composer schools, noted that the beginning of the twentieth century was marked by the doctrine of the noosphere by P. Teilhard de Chardin and V. Vernadsky as the spiritualized energy sphere of the

${ }^{6}$ Skrypnik, A. (2009). Fenomen aleatoriki v tvorchestve kompozitorov XX veka: estetikokul'turologicheskiy aspekt. Naukovyi visnyk Natsionalnoi muzychnoi akademii Ukrainy imeni P.I. Chaikovskoho, 75: Kompozytor i suchasne sotsiokulturne seredovyshche, 155-171.

\footnotetext{
${ }^{7}$ Ibid., p. 155.

${ }^{8}$ Ibid., p. $155-156$.

${ }^{9}$ Ibid., p. 156.
} 
macrocosm, integrated with the individual microcosm of the composer. An example of the embodiment of cosmic ideas is the work of A. Skryabin, in particular, his composer's technique. In the thinking of A. Skryabin irrationality is associated with the manifestation of randomness, plurality, variability. An important element in understanding the origin of randomness is a synergetics, which supposes a constructive factor in the processes of self-organization ${ }^{10}$.

The philosophical understanding of randomness is associated with two types of randomness, namely, randomness which produces multiplicity options and randomness producing uncertainty. The effect of randomness on the macro level is related to the inclusion in the dynamic system, marked by the state of instability that is characteristic for musical art of the second half of the twentieth century. Herewith, the randomness causes endless replication with infinite multiplicity of variant opportunities and unpredictability. It is the modern philosophical interpretation of randomness that allows "... to substantiate the aesthetic nature of aleatory in artistic creativity, to understand the underlying causes and mechanisms of its manifestation in musical art"11. Among the factors of occurrence of aleatory the game one is considered to be important, accumulating probabilistic plurality, unpredictability, randomness. Game regularities, the key principle of which is randomness, were used by John Cage in the composition process involving gambling bones, maps, ancient Chinese book of fortune telling (The Book of Changes - I Ching). It is J. Cage who in the creation of the aleatory composition uses the principles of the game theory, associated with stochasticity of sound process. The game components of the aleatory composition are used as a constant model with the regulation of all parameters, that are characteristic for the creativity of J. Cage and K. Stockhausen, where stochasticity is associated with "unlimitedness", "totality"12.

The game components of the "limited", "controlled" action are used in the aleatory compositions of Ukrainian composers Y. Stankovych, V. Silvestrov, G. Lyashenko, I. Karabits, V. Zubytsky, M. Kovalinas, V. Runchak, O. Skrypnyk and West European composers P. Boulez, W. Lutosławski. Game principles are manifested in the improvisation of instrumental parties of orchestral groups, dynamic plans, colorist, stroke and nuanced techniques. In the above-indicated article O. Skrypnyk analyzes several works:

\footnotetext{
${ }^{10}$ Skrypnik, A. (2009). Fenomen aleatoriki v tvorchestve kompozitorov XX veka: estetikokul'turologicheskiy aspekt. Naukovyi visnyk Natsionalnoi muzychnoi akademii Ukrainy imeni P.I. Chaikovskoho, 75: Kompozytor i suchasne sotsiokulturne seredovyshche, 155-171.

${ }^{11}$ Ibid., p. 159.

${ }^{12}$ Ibid., p. 163.
} 
"Concert No. 1 for Piano and Strings" (1979), "Penitent verse for Violin and String Orchestra" (1989), "Aria-Passiona 2" (Chamber Symphony No. 3 for viola and Chamber Orchestra) (2000). Igor Shcherbakov uses game components fragmentary in the context of the principles of limited aleatory technique. "Indeterminate" musical episodes create “... a necessary psychological or colour background" in one case; in the other, they invade the dramaturgic process, introducing "imaginary" freedom into a well-thought-out algorithm of the work"13.

In the Concert No. 1 for piano and strings (tact 24-25) in a cello party (in the form of squares), " $\ldots$ the composer captures movement from note to note using glissando"14. The gaming components are found in the variant performing interpretation, in the dialogic form of interaction between the orchestral and piano parties ${ }^{15}$. In the party of violins (tact 49-50, 53) “... the composer uses squares of Pizzicato. Despite the precise sound-pitch definition and the sufficiently expressive metric introduction of voices, the absence of rhythmic differentiation $<\ldots>$ "the game components are freely interpreted by the performers of durations ${ }^{16}$. The game elements change the semantic results of identical methods of aleatory technique "... the canonical introduction of voices, designed in the form of squares, provides for free metric reading by performers within the tact" ${ }^{\prime 17}$.

The game elements are manifested in dynamic changes from (pianissimo crescendo - to four forte), which is achieved using the movement of the sonorous stratum. In Quasi Cadenza the aleatory game (tact 191-196) is traced in the piano solo, the technique of microchromaticity of all instruments, undifferentiated sound flow, creating the effect of the sonorous mass. The game is also manifested in the constant change of metric introductions, denoted by a square in the parties of performers, which implies interpretative variability ${ }^{18}$. In addition, the author of the article focuses on the manifestation of game factors in the artistic concept of the work - in comprehension of “... multi-directional flows of time in the complex plexus of the present, past and future, closed in the horizontal-vertical projection of the reflective consciousness"19.

${ }^{13}$ Skrypnik, A. (2009). Fenomen aleatoriki v tvorchestve kompozitorov XX veka: estetikokul'turologicheskiy aspekt. Naukovyi visnyk Natsionalnoi muzychnoi akademii Ukrainy imeni P.I. Chaikovskoho, 75: Kompozytor i suchasne sotsiokulturne seredovyshche, 155-171.

${ }^{14}$ Ibid., p. 165.

${ }^{15}$ Ibid.

${ }^{16}$ Ibid., pp. 165-166.

${ }^{17}$ Ibid., p. 165.

${ }^{18}$ Ibid., p. 166.

${ }^{19}$ Ibid. 
In the work of I. Shcherbakov "Repentant verse" for violin and string orchestra O. Skrypnyk notes the fragmentary use of aleatory. The composer' activates game elements "... as a dynamic crescendo in the form of squares with a certain rhythmic formula in the diagonal texture (tact 46-55) of the entire orchestra, except violins (1-2) of the group of first violins" ${ }^{\text {"20 }}$. The manifestations of the principles of the game are connected with the time of the introduction of instruments and improvisation in the process of performing, and the diagonal texture increase in combination "... with autonomous rhythmic formulas create expressive aleatory-sonorous stratum that is moving" 21 .

The composer "plays" with the rhythmic formulas, the texture-sonorous strata, the number of notes in squares of various groups of instruments, the regulation of the time "... of the sounding of mobile fragments $<\ldots$.. " within the limits of one tact, the regulation of the sounding of a square with the quantity designation of beats in the tact (tact 58 and 60) ${ }^{22}$. The game is traced in a dynamic plan: ".. a metric displacement, which depends on the free reading of the pace (speed) of the squares (four note durations in each square thirty second) creates the impression of the arbitrariness of the performing fragment" (tact 63-66) ${ }^{23}$. O. Skrypnyk focuses on the soloist's party (tact 64, 67-72) and in Quasi cadenza (tact 96, 98-99, 101), in which “... a rhythmic acceleration is written during one tact or a certain number of beats in a tact. It begins conditionally, from eighth durations and ends with thirty second durations. The composer accurately fixes the sound-pitch, controls the timing of rhythmic accelerations (within the limits of the tact or a certain amount of beats within the tact), but writes out the randomness of the number of repetitions by the notegraphy. The soloist decides on his own the need of one or another number of rhythmic repetitions, and each time during a new performance the number of repetitions may change" ${ }^{24}$. This is where the elements of the game in the party of the soloist are revealed and, in addition, the composer uses the elements of the game in the dramaturgic plan of the work“... in preculminating" (orchestra) and culminating (soloist) zones ..."25.

In the work "Aria-Passiont 2" (Chamber Symphony No. 3 for viola and chamber orchestra) of I. Shcherbakov the game elements of the aleatory technique appear fragmentarily, using three times the "... squares in the score

${ }^{20}$ Skrypnik, A. (2009). Fenomen aleatoriki v tvorchestve kompozitorov XX veka: estetikokul'turologicheskiy aspekt. Naukovyi visnyk Natsionalnoi muzychnoi akademii Ukrainy imeni P.I. Chaikovskoho, 75: Kompozytor i suchasne sotsiokulturne seredovyshche, p. 166.

${ }^{21}$ Ibid., p. 167.

${ }^{22}$ Ibid.

${ }^{23}$ Ibid..

${ }^{24}$ Ibid., p. 168.

${ }^{25}$ Ibid., p. 167. 
(tact 16, 19, 22) of the first violins, second violins and altos within a tact, when reproduced with the use of canonical introduction (textured crescendo), free readings of the pace by the performers, create each time lit in a new way sound spots" ${ }^{\prime 26}$. The game principles are manifested in the colouristic change of the sonorous stratum with the invariable time of the introduction and the ending of sounding of the square.

In Ye. Kharchenko's article "The Phenomenon of the Game" in Piano Miniatures of the 1990-2000s (on the Example of Piano Works by K. Tsepkolenko, S. Pilyutikov, I. Shcherbakov)" ${ }^{\text {27 }}$ are revealed the peculiarities of forming the national concept of postmodernism in musical culture with a focus on piano creativity. In the context of contemporary problems of globalization, the vector of creativity of Ukrainian composers is connected with non-revival, spiritual search. Creative pursuits in both the days of classicism, romanticism, avant-garde and postmodern are indicated by the appeal to the genres of piano music. The foundations of Ukrainian postmodernism are based on the revival of baroque, classicist, romantic and avant-garde traditions. There is a re-arrangement of the images and forms of the past, the mixing of genres and styles; the proportion of the intellectual component in creativity has been increased.

The modern cultural paradigm requires an update of the value system of coordinates. According to Ye. Kharchenko's definition: "The absurdity of modern life, its illusory, unnatural, chaotic nature, have provoked an elevated postmodern game style. Such a characteristic feature is drawn by many musicologists and searches in the field of contemporary creativity of Ukrainian composers"28. New piano works by contemporary Ukrainian composers illustrate the idea of the interaction between game and music.

In the context of the typological principle, the game factor applies Karmella Tsepkolenko, introducing the line of I. Stravinsky and S. Prokofiev. Samples of "phenomenon of game" in musical art are shown by S. Pilyutikov and I. Shcherbakov.

In K. Tsepkolenko's play "Evening Solitaire" (otherwise called "Card Game № 2") the principle of play is mediated through performance as an aesthetic manifestation of the "art of action". The composer uses the

${ }^{26}$ Skrypnik, A. (2009). Fenomen aleatoriki v tvorchestve kompozitorov XX veka: estetikokul'turologicheskiy aspekt. Naukovyi visnyk Natsionalnoi muzychnoi akademii Ukrainy imeni P.I. Chaikovskoho, 75: Kompozytor i suchasne sotsiokulturne seredovyshche, p. 168.

${ }^{27}$ Kharchenko, Ye. (2009). "Fenomen ghry" u fortepiannykh miniatjurakh 1990-2000-kh rr. (na prykladi fortepiannykh tvoriv K. Cepkolenko, S. Piljutykova, I. Shherbakova). Naukovyi visnyk Natsionalnoi muzychnoi akademii Ukrainy imeni P. I. Chaikovskoho, 84: Kompozytor i suchasnistj, 130-142.

${ }^{28}$ Ibid., p. 133. 
principles of playing in the form of solitaire decomposition and "ejection of cards" by the performer-pianist, that is indicated in the note text, figuratively dramatic plan forms the use of rhythmic pedal technique that corresponds to certain musical durations. The play is manifested in the use of temporal and acoustic spaces, combination of free atonality with the stage, theatricality.

In the work "From the Blues" by Karmella Tsepkolenko, as the author of the article notes, the game manifests itself in nostalgia "by the value criteria of earlier eras" 29 . Using the performance genre, the composer presents the blues in an avant-garde manner; combines sonoristics with jazz-style chords; piano improvisation articulated by the logic of the development of musical thought with a performance situational game.

K. Tsepkolenko in her work "Landscape-Solo" represents a game with figurative-listening and performing associative thinking. To reproduce the landscape, a system of "musical and expressive resources" is involved ${ }^{30}$ with giving at the end of the work "used system of symbols and abbreviations" 31 . The coloristic nature of sound resources is linked to the imaginative realm of the landscape, and the solo integrates an in-depth psychology with the instrumental content of the work. The composer does not limit the performer's imaginative and associative thinking and gives him the opportunity to use a free fantasy game. In addition, the elements of the game are assumed by the composer in the event of various performances.

The imaging sphere of the work is related to the seascape, the play elements of which are dramaturgy of two moods - calm and storm, embodied in two-part construction, tempo changes, vibrations of dynamic shades, different register sounds. The realization of the image-dramatic development is carried out by K. Tsepkolenko using the "game" of improvisationalchromatic technique for the reproduction of fragmentary movable ostinato, "sound blocks" that are formed into sound layers, created by the technique of controlled aleatory; also the pointillist technique is employed.

In the above article, Ye. Kharchenko analyzes the work "Play the game" by Sergei Pilyutikov, in which the musical space is represented in accordance with the game principles with the use of style play, aleatoric play of fragments and textured fabric. The author of the article states: "Here the concept of play is used in the sense of both playing the piano and aleatoric technique as

${ }^{29}$ Kharchenko, Ye. (2009). "Fenomen ghry" u fortepiannykh miniatjurakh 1990-2000-kh rr. (na prykladi fortepiannykh tvoriv K. Cepkolenko, S. Piljutykova, I. Shherbakova). Naukovyi visnyk Natsionalnoi muzychnoi akademii Ukrainy imeni P. I. Chaikovskoho, 84: Kompozytor i suchasnistj, p. 136.

${ }^{30}$ Ibid., p. 137.

${ }^{31}$ Ibid. 
playing with elements of a work" ${ }^{32}$. Composer's processing of sound elements is done by using combinatorial principles. Game principles are traced in the application of such techniques as pointillism, polyphonic bundles and agogic accents $^{33}$.

The composer's attention is focused on textures that are enriched by "small seconds from different sounds" ${ }^{34}$, one trill integrates with another, causing game finds with a sound vertical. According to the author, further development is determined by the transformation of "... vertical to horizontal" with the inclusion of the game "of different textural and rhythmic formations, four waves of development of the "game" with the game that are formed ${ }^{35}$.

In the work "Lullaby" by S. Pilyutikov, the properties of the game are realized by means of musical expressiveness. The composer develops the basic sound motif (complex) as a series, performs game variations with interval "overlays", their "clutches", transpositions, variations of major and minor. Interval overlays extend the textural and audio range. Changes in the color complex of the sound complex in each beat are made using polyphonic techniques, dynamic nuance, integration of pointillist technique with the development of melodic line. Game factor is manifested in aleatory, improvisation, dissonant harmonic layers ${ }^{36}$.

Analyzing Igor Shcherbakov's work "LiebesTod. Afterword" Ye. Kharchenko sees a manifestation of the play factor in a veiled conceptualism. The first part of the title encrypts the music of Western European composers, namely R. Wagner (opera "Tristan and Isolde"), the second part of the title is related to the properties of temporal space, where the dramatic "intonation-symbols" are concentrated ${ }^{37}$. The author of the article notes that "the composition is based on the leitons, themes and symbols that have passed through the age space and remain relevant to modern life (Sonata Op. 27 No. 2 cis-moll and motif of Fate from the Fifth Symphony by

${ }^{32}$ Kharchenko, Ye. (2009). "Fenomen ghry" u fortepiannykh miniatjurakh 1990-2000-kh rr. (na prykladi fortepiannykh tvoriv K. Cepkolenko, S. Piljutykova, I. Shherbakova). Naukovyi visnyk Natsionalnoi muzychnoi akademii Ukrainy imeni P. I. Chaikovskoho, 84: Kompozytor i suchasnistj, p. 138.

${ }^{33}$ Ibid., p. 139.

${ }^{34}$ Ibid.

${ }^{35}$ Ibid.

${ }^{36}$ Kharchenko, Ye. (2009). "Fenomen ghry" u fortepiannykh miniatjurakh 1990-2000-kh rr. (na prykladi fortepiannykh tvoriv K. Cepkolenko, S. Piljutykova, I. Shherbakova). Naukovyi visnyk Natsionalnoi muzychnoi akademii Ukrainy imeni P. I. Chaikovskoho, 84: Kompozytor i suchasnistj, p. 140.

${ }^{37}$ Ibid. 
L. van Beethoven, "Reflection" Intonations of "The Love Dreams" by F. Liszt)" ${ }^{38}$.

In a three-part reprise form the first part of the work is semantically linked to romantic keynotes - the music is encrusted with Isolde's leitem, the trio's rhythm base as an allusion to Sonata op. 27 No. 2 cis-moll by L. van Beethoven, "Flares" of F. Liszt's "Dream of Love",39.

The composer's "Everything is Blurry and smeared with Pedal" defines the playwriting of the second section. According to Ye. Kharchenko, for the reproduction of the "sound of Eternal time" the composer employs a pedal vibrato, a tremolo of reduced septa chords, to embody the sonar effect associated with temporal space ${ }^{40}$. Through the textural injection erupts the "Fate motif" of L. van Beethoven's Fifth Symphony <... >“411.

In the third section of the code, the composer includes all of the previously involved "leytinton structures and "blurs" the musical fabric of tremolo", in which the Fate motif sounds till the last tact"

Game patterns in the work are manifested in the philosophical understanding and comprehension of historical events; images of the past are encrusted in the "text of modern musical language" ${ }^{43}$. The trends of musical postmodernism synthesize the creative discoveries of previous eras.

The concept of scientific investigation of Bogdana Maksymenko "Rational and intuitive in the work of Vitaly Hodzyatsky "Game" is based on the principle of manifestation of the synthesis of intellectual and creative maxims. The work "Game" completes the cycle "Characteristic scenes", which includes seven plays - "portrait sketches of someone from the author's close people" 44 . The focus of the study is due to the programmatics of the work "Game", which is represented by the duality of rational and intuitive. Rational principles are related to game principles, and intuitive, in accordance, to the creative. Rational maxims in the work are realized for the use of stable structural elements, quantitatively limited, that are used in the sequence defined by the composer. As a stable output constant, a twelve-tone scale with a division into two sound combinational sequence is detected. The central

${ }^{38}$ Kharchenko, Ye. (2009). "Fenomen ghry" u fortepiannykh miniatjurakh 1990-2000-kh rr. (na prykladi fortepiannykh tvoriv K. Cepkolenko, S. Piljutykova, I. Shherbakova). Naukovyi visnyk Natsionalnoi muzychnoi akademii Ukrainy imeni P. I. Chaikovskoho, 84: Kompozytor i suchasnistj, p. 141.

${ }^{39}$ Ibid.

${ }^{40} \mathrm{Ibid}$.

${ }^{41}$ Ibid.

${ }^{42}$ Ibid.

${ }^{43}$ Ibid.

${ }^{44}$ Shurova, N.S. (1999). Vitaliy Godzyatskiy. Shtrikhi k portretu. Green Lamp, 3-4, 50-51. 
structure-forming element, according to the conception of V. Hodzyatsky, is a twelve-tone scale as the key principle of predecaphonical technique.

The elements of the game are two sound-pitch structures: the first "sound combination" is the alternation of the sound "a" with the big tertsia "ges/B", and the second is the sequence of sounds "c-des-as-es-g-h-d-f-e" 45 .

The structural analysis, as the author of the article points out, allowed to reveal two plans of sound tissue, namely, the sound-pitch constant obstinate movement in the first combination and the sound-pitch "ostinato" in the free register location and the interval segment (step) of the second combination. The game strategy of the composer's composition is based on a combinatorial principle - it is the sound-pitch obstinate repetition in the first combination and the scale one in the second combination. At the same time, the iterations alternately change - rhythmically (in both structural combinations); with chords (part I of the work); consistently (part II of the work); by register (part II of the work) and metrically. Precisely metrical changes - the shift of emphasis, varying size (using the "eighth progression or regression between stressed beats") ${ }^{46}$. The above-mentioned strategy of deploying a musical work is the area of rational. Regarding the intuitive sphere, its manifestations consist in choosing variants of "obstinate sound combinations" (metrorhythmic and registering) ${ }^{47}$. The emergence of new variants depends on the creative imagination of the composer. The logic of composer thinking determines the sequence of variants of sound combinations and, by definition of B. Maksymenko, "... here it cannot do without a rational, thought-out general plan of musical form, which can be defined as a two-part with an enlarged (extended) second part ..."48. Thus, in particular, in relation to the formative dramaturgy in the first part of the work, "Game", the composer introduces into the sound material of the first combination elements of variability - the use of pause, various rhythms, analogously to the variantcombination process of thinking in chess. In the second combination, both temporal (horizontal) and spatial (vertical) parameters are involved.

Precisely the changes in the harmonic components form new sound systems that affect the texture variability of the sound tissue. The phenomenon of arches, the continuous game between the first and second parts is formed by the use of the beginning notes of the second sound combination at the end of the first part of the work and which creates an

${ }^{45}$ Maksymenko, B.O. (2008). Ratsionalne ta intuityvne u tvori Vitaliia Hodziatskoho "Hra". Naukovyi visnyk Natsionalnoi muzychnoi akademii Ukrainy imeni P.I. Chaikovskoho, 73: Muzychna tvorchist ta nauka v istorychnomu prostori, 219-226.

${ }^{46}$ Ibid., p. 221.

${ }^{47}$ Ibid., p. 222.

${ }^{48}$ Ibid. 
integral deployment of the second part, simulating the game. And in this process of the game, in contradistinction to the scale ostinato, the temporal parameter in the form of the rhythm of eighth (eighth rhythm), in integration with the inclusion of natural musical intonations, caesura pauses and variable size, is detected as more weighty.

Examining the sound deployment of the second combination, the author of the article (B. Maksymenko) notes that its melodic presentation "... moves in the opposite interval direction from the previous one"49, while as the choice of the interval step of the register location is constantly changing, depending on the previous presentation of the sound combination, which is the manifestation of the intuitive start of time-space.

The variational changes are the characteristic feature of the first combination of the second part - the shift of emphasis, the change of duration (for small) and the rhythmic complications of the picture (syncope, aligned duration in combination with dashed rhythm, which creates a game of stressed and unstressed beats of two sound elements of the combination ${ }^{50}$. The game factor in the work is manifested not by the causal logic but by the characterized by the author of the article (B. Maksymenko) as "kaleidoscopic" one ${ }^{51}$. The causeeffect relationships of the "kaleidoscopic" logic are manifested in the previous sound situation with the certain immutability of the original material of the composition. The composer creates musical structures marked by stability with the introduction of pattern variability, and the chord completion of the work combines the original "c" and the sounds of the second combination, which is evidence of the manifestation of the game component. The analysis given by the author of the considered scientific investigation allows us to draw conclusions about the existence of logical-constructive principles of musical thinking in the creative work of V. Hodzyatsky, which are implemented by the composer using the laws of the intellectual game.

\section{Author's method of structural analysis of piano works by composers of the first third of the twentieth century:}

\section{A. Skryabin and M. Verykivsky}

In our study, the principles of game theory relate to combinatorics as a structural method of analyzing the A. Skryabin's harmonic system a system of large, not limited, as in classical music, number of elements that make it up.

\footnotetext{
${ }^{49}$ Maksymenko, B.O. (2008). Ratsionalne ta intuityvne u tvori Vitaliia Hodziatskoho "Hra". Naukovyi visnyk Natsionalnoi muzychnoi akademii Ukrainy imeni P.I. Chaikovskoho, 73: Muzychna tvorchist ta nauka v istorychnomu prostori, p. 224.

${ }^{50}$ Ibid.

${ }^{51}$ Ibid., p. 225.
} 
Chord structures vary in the number of sounds (from 3-tone to 12-tone structures), while at the same time in classical harmony it is mostly 3-4 sounds - triangles and septa-chords. Multi-sound chord structures (5-12 sound) - are varied in the mutual arrangement of sound elements in a harmonious vertical and texture-configuration horizontal.

The complicated type of harmonic system of A. Skryabin causes considerable individualization of textural and harmonic processes, which makes it necessary to apply a combinatorial method of analysis to the composer's creativity.

The essence of this structural method in information theory is that it represents one of the aspects of constructing and transforming the system of "messages" in the form of signs or in relation to our study of sounds. The regularities of combinatorics are related to the construction of elements of the original set, a derivative set called the combinatorial configuration. Such configurations include placement, rearrangement and connections.

The originality of A. Skryabin's late harmony lies precisely in the fact that each of the shortest in time exposures vertical projection of the textured complex forming any of the variants of the "Promethean" structure. That is, in multi-sound chord structures there is a leveling of the non-chord sounds that make up the "micro-vertical".

It should also be noted that in the chordal linkages of Late Skryabin's harmony, the dominant value belongs to voting, not harmoniously functional feature. Thus, its diversity is due, first of all, to interaction with textural factors of development. Multilingual chord structures can form an equirhythmic vertical, due to the integrated, almost "cluster" sounding, and A. Skryabin often used it in the works of later opuses.

The game regularities in our study are connected with combinatorics, as a structural method of analysis of piano creativity of A. Skryabin of the late period and piano creativity of M. Verykivsky, in particular, the discovery of certain properties of the harmonic language in the heritage of composers.

The study of the late-Skryabin harmonic system (on the example of Preludes, Op. 67 No. 1-2) using the combinatorial method of analysis and the author's heuristic computer program "MyAccord.exe." written in the programming language " $\mathrm{C}++$ ", allowed to find the manifestations of the game regularities and to make a number of important conclusions on the logical and constructive principles of musical thinking of the composer. Thus, the game factors in the late harmony of A. Skryabin are marked by an increase in quantity of sound-cells in chord structures (five, six, seven and more), which leads to an increase in the combinatorial variants of chord placement, and is accompanied by an exit beyond the boundaries of tertian texture.

However, with a considerable variety of constructively possible polyphonic chords in the work of A. Skryabin, namely in his late period 
(in comparison with classical and romantic harmony), there is a rather limited selection of sound elements and chords, their concrete-thematic implementation, which led to the formation of a "Promethean complex" not only at the level of individual chord structures, but also at the level of the integral construction of the work.

The obtained results of the study of harmonic language in the late period of the work of A. Skryabin make it possible to make the conclusion regarding the quality of the sound system that it is a compex-organizied orderly system with unequally probabilistic distribution of sound events values, which is manifested in combinatorial diversity, game principles, permutational changes in chord structures and intonation selection, the formation of an invariant centre in the form of "Prometheus complex". The idea of a combinatorial game is especially important in Skryabin's works, the difference of which lies in the variational-acoustic development of musical material.

The scientific novelty of the conducted research is to extrapolate the principles of the theory of games to the piano creativity of A. Skryabin of late period.

The unpredictability of the stochastic process, the variability, uniqueness, spontaneity that inherent in the game, are characterized by certain laws - the rules of the game, a kind of "algorithms" of a complex organized process.

It is this sense of "game", the unpredictability of the spontaneous process, which is perceived by the receptive consciousness in the music of the late period of A. Skryabin's creativity, which has direct confirmation in the study of combinatorial probabilistic-stochastic processes in the harmonic language of the composer.

The functioning of the game combinatorial principles of the organization of musical material is observed in the piano creativity of M. Verykivsky, in particular, in Preludes № 1 and № 11. The development of Prelude № 1 is determined by modulating sequential constructions (tact. 1-2), which in horizontal form reflect the structure of Skryabin's "Promethean chord". The use of the combinatorial method of analysis allowed to reveal the configurative game, permutative principles of the construction of musical tissue, which are assimilated with the idea of "Promethean complex". In the development of the musical material of Prelude № 11 the mode-scale principle of the non-accordion type is used with the inclusion of the elements of the mixolydian mode, the tonal discreteness, and the variability in the functioning of the invariant complex in the form of increased triplet-sound. The beginning of the Prelude (first line, tact. 1-2) is marked by a differentiated representation of the harmonic structure, which forms a diffuse complex-configurative structure in the subsequent game permutations (first line, tact № 3 and second line, tact № 1). Thus, in the development of this Prelude, a certain dynamics can be traced from the scale as an initial 
"code" with subsequent development in the form of the scale complex multiplicity and with its subsequent transformation into the polyphonic chords that form the simultate complex.

\section{CONCLUSIONS}

The research is focused on the analytical representation of the fields of application of the game theory in contemporary musicology. There were considered theoretical and musicological tendencies connected with the methods of exact sciences, in particular theoretical and game regularities with their extrapolation to composer's creativity, thematic development of the musical composition's form, structural and analytical study of musical works, study of logical and constructive principles of musical thinking.

Game patterns are also detected in folk polyphony. In Ukrainian and Russian folklore, heterophonical kind of polyphony has received the greatest development, which is characterized by simultaneous combination of different variants of the same melody with vocal, instrumental or mixed performance.

The main provisions of the theory of games were applied in musicology by a composer Iannis Xenakis for composing of his music. Two groups of musicians use the spontaneity in the process of perfomance, where each state determines the strategy of the game, which is conducted according to the matrix of the transition. The combinatorical principles are used a little differently in the composition "Strategy" by I. Xenakis for two orchestras, in which the game situation is shown through the duration and speed of execution of combinatorical combinations.

In the work of contemporary composers the principles of a game are embodied in using of diversified methods of dodecaphonic and aleatoric techniques, involvement of intellectual game patterns, temporal and acoustic spaces, integration of free atonality with the elements of theatricality and improvisation with performing situational game.

In the conditions of "information" complexity of the harmonic language of composers A. Skryabin (late period of piano creativity) and M. Verykivsky (piano creativity) heuristic computer technologies allowed to reveal internal connections between harmony and texture, to trace regularities, peculiar "algorythm" of the process in the musical thinking of composers, their logical and constructive principles.

The unpredictability of the stochastic process, the variability, uniqueness, spontaneity that inherent in the game, are characterized by certain laws - the rules of the game, a kind of "algorithms" of a complex organized process. It is this sense of "game", the unpredictability of the spontaneous process, which is perceived by the receptive consciousness in the music of the late period of A. Skryabin's creativity, which has direct confirmation in the study of combinatorial probabilistic-stochastic processes in the harmonic language of the composer. 
In the conditions of the "information" complexity of the harmonic language of such composers as A. Skryabin (late period of piano creativity) and M. Verykivsky (piano creativity), heuristic computer technologies allowed to reveal the internal connections between harmony and texture, to trace the regularities, the peculiar "algorithms" of the complex-organized process, penetrate into the mechanisms of the musical thinking of the composers, their logical-constructive principles. The unpredictability of the stochastic process, the variability, unrepeatability, and spontaneity which are inherent in the game, are characterized by the certain laws - the rules of the game.

Precisely in the study of the texture-harmonic system of A. Skryabin's late period of piano creativity and the piano creativity of M. Verykivsky the theoretical-game regularities are manifested in the projection of the dialogic level on the cause-effect dependencies, combinatorics of sound-cells and the manifestation of permutation. Extrapolation of the principles of game theory to the study of composer's creativity, with the focus on the principles of continuity in piano creativity of A. Skryabin and M. Verykivsky, allowed finding the manifestations of spontaneous and compositionally-conscious processes in the musical thinking of composers.

\section{SUMMARY}

The study deals the manifestation of the game theory regularities in composer work. The methodology of the research is in using the musicological, system-structural, probabilistic, game-theoretical and stochastic methods. This methodological approach allows to analyze the piano creativity of A. Skryabin and M. Verykivsky. The scientific novelty of the study is in extrapolation of the regularities of the games theory into the processes of musical thinking of A. Skryabin and M. Verykivsky with the discovery of their logical constructive principles and tendencies of continuity. In the conditions of the "information" complexity of the harmonic language of such composers of the first third of the twentieth century as A. Skryabin and M. Verykivsky, heuristic computer technologies allowed to reveal the internal connections between harmony and texture, to trace the regularities, the peculiar "algorithms" of the complex-organized process, penetrate into the mechanisms of the musical thinking of the composers, their logicalconstructive principles. The unpredictability of the stochastic process, the variability, unrepeatability, and spontaneity which are inherent in the game, are characterized by the certain laws - the rules of the game. In the study of the texture-harmonic system of the late period of piano creativity of A. Skryabin and the piano creativity of M. Verykivsky, the theoretical game regularities are manifested in the projection of the dialogical level of causeeffect dependence, combinatorics of sound elements and the manifestation of permutations. Extrapolation of the principles of the game theory, with the 
focus on the principles of continuity in the piano creativities of A. Skryabin and M. Verykivsky, allowed to find manifestations of spontaneous and compositional-conscious processes in the their musical thinking.

\section{REFERENCES}

1. Akopyan, L.O. (1986). Iskhodnye printsipy formalizovannogo analiza muzykal'nogo teksta. In Strukturnyy analiz teksta: sb. statey AN Armyanskoy SSR, 2. Yerevan: AN Armyanskoy SSR (pp. 210-220).

2. Hominsky, J. (1975, 1979). Istorija gharmoniji ta kontrapunktu. Kyiv: Muzychna Ukraina. (Vols. 1, 2).

3. Kharchenko, Ye. (2009). "Fenomen ghry" u fortepiannykh miniatjurakh 1990-2000-kh rr. (na prykladi fortepiannykh tvoriv K. Cepkolenko, S. Piljutykova, I. Shherbakova). Naukovyi visnyk Natsionalnoi muzychnoi akademii Ukrainy imeni P. I. Chaikovskoho, 84: Kompozytor i suchasnistj, $130-142$.

4. Maksymenko, B.O. (2008). Ratsionalne ta intuityvne u tvori Vitaliia Hodziatskoho "Hra". Naukovyi visnyk Natsionalnoi muzychnoi akademii Ukrainy imeni P.I. Chaikovskoho, 73: Muzychna tvorchist ta nauka v istorychnomu prostori, 219-226.

5. Mukha, A.I. (1979). Protsess kompozitorskogo tvorchestva: problemy i puti issledovaniya. Kyiv: Muzychna Ukraina.

6. Nazaykinsky, Ye.V. (1982). Logika muzykal'noy kompozitsii. Moscow: Musyka.

7. Owen, G. (1971). Game Theory: translation from English. Moscow: Nauka.

8. Skrypnik, A. (2009). Fenomen aleatoriki v tvorchestve kompozitorov XX veka: estetiko-kul'turologicheskiy aspekt. Naukovyi visnyk Natsionalnoi muzychnoi akademii Ukrainy imeni P.I. Chaikovskoho, 75: Kompozytor i suchasne sotsiokulturne seredovyshche, 155-171.

9. Shurova, N.S. (1999). Vitaliy Godzyatskiy. Shtrikhi k portretu. Green Lamp, 3-4, 50-51.

10. Xenakis, Ia. (1971). Formalized Music thought and mathematics in composition. London: Indiana University Press, Bloomington.

\section{Information about the author: \\ Kateryna Fadyeyeva,}

Doctor of Arts, Associate Professor,

Professor of the General and Specialized Piano Department, Petro Tchaikovsky National Music Academy of Ukraine 1-3/11, Architect Gorodetsky str., Kyiv, 01001, Ukraine https://orcid.org/0000-0003-2329-469X 


\section{POLY SYSTEM ANALYSIS OF VISUAL COMMUNICATION IN FASHION}

\section{Olga Shandrenko}

\section{INTRODUCTION}

The active development of the media of the technical arts (photography, cinema, advertising), universal computerization, have led to the transformation of the realities of cultural imagery that have influenced the communication processes as a whole. The phenomenon of fashion in this work is explored as a socio-cultural phenomenon, which by its very nature is total communication. Every person who participates in the social life of society, regardless of whether it adopts or opposes fashion, becomes an agent of fashionable information in the cultural space.

With the information technologies development and their impact on society, understanding of the sign function of fashion in the context of communicative mechanisms becomes especially relevant. Therefore, in the social life of a society, the act of communication is the process of dissemination, exchange, transmission of information and a certain connection that occurs through communication channels and mechanisms. It is accepted that verbal communication is carried out as the interaction of people with the help of audio language, which includes a system of phonetic signs (the principle of phonetic and syntactic), and non-verbal communication occurs without words, with the help of gestures, gestures, facial expressions. Fashion and clothing, the manner of dressing, we are regarded as a specific cultural language, possessing properties relevant to the communicative phenomenon. According to authors Joseph Hiz and Andrew Potter, clothing is language-like, with its own grammar and syntax in expressive means that can joke, make comments, use metaphors, and use slang ${ }^{1}$. This is the opinion of M. Lusher in the work "Personality signals". Alison Lurie in the work "The clothing language", claiming that clothing is the vocabulary of the individual by which, before the verbal conversation begins, a conversation is made in a more archaic universal language.

Fashion as a complex, multifaceted phenomenon of culture, requires a complex, multidisciplinary approach, leads to the definition of the

${ }^{1}$ Khiz, Dzh. \& Potter, E. (2007). Bunt na prodazhu. Moscow: Izdatel'stvo "Dobraya kniga".

${ }^{2}$ Lyusher, M. (1996). Signaly lichnosti. Khar'kov: AO Sfera.

${ }^{3}$ Lurie, A. (1981). The Language of Clothes. London: Bloomsbury. 
communicative function of fashion in the space of culture of the XX-XXI centuries. The study of visual communication in fashion makes it possible to see the subject of fashion discourse (designer, artist, fashion designer, photographer, advertiser, etc.), which, in turn, presents a form of discourse presentation (language, sign, callisthenics, shaping, photography, advertising, brand, corporate identity). This should take into account the analysis of the definition of a figurative presentation, as well as how and how communication occurs. Therefore, there is a need to determine the relationship of understanding and perception of the information message.

It is important to determine how a set of characters, characters used in fashion, encourages creative coexistence in the discourse that emerges in the process of visual communication.

\section{Discoursive practices of fashion}

The use of the ambiguous word "discourse" (fr. discourse, English discourse, from Latin discursus is running back and forth; movement, circulation; conversation, conversation, linguistic activity) in modern culture has become more widely used in the second half of the twentieth century. The reason for this popularity was the so-called linguistic turn that extended structuralist methodology and structural linguistics to all areas of science. Modern researchers O. Rusakov and V. Rusakov note that the understanding of discourse has been determined by the principle of focus in the scientific literature, and determine the appropriate scientific methods: linguistic, semiotic, social-communicative, cratological, postmodern, critical discourse analysis, presentation. However, as the authors note, "there is no "pure" approach to the study of the discourse phenomenon, which does not contain elements of other theories, which testifies to all existing concepts developed on the basis of the development of intellectual dialogue and interdisciplinary research" 4 .

The interpretation of culture as the totality and integrity of discourses as the unity of languages was extended by the French structural school, which made it relevant to the question of temporality, temporality, as the dominant of discursive practices. The scientific understanding of discursive practices is laid down in the works of M. Foucault ${ }^{5}$. The scientist determines the influence of the "historical unconscious", as the linguistic nature of thinking, on human activity in relation to discursive practices (linguistic practices). Such an understanding of discursive practices by M. Foucault we also adapt to the understanding of the

\footnotetext{
${ }^{4}$ Rusakova, O.F. \& Rusakov, V.M. (2008). PR-Diskurs: Teoretiko-metodologicheskiy analiz. Ekaterinburg: UrO RAN, Institut mezhdunarodnykh svyazey, p. 5.

${ }^{5}$ Fuko, M. (1996). Arkheologiya znaniya. Kyiv: Nika-Tsentr.
} 
phenomenon of fashion and try to identify discursive practices that can also be seen as a set of certain historical (periodic, temporal, temporal) rules that are determined in time and space. Such rules set the conditions for the existence and spread of fashion in a particular era and in a particular cultural environment. In this study, the definition use "fashion" we use in relation to the rule, creating, distributing certain norms, rules of conduct on the appearance of man, his clothes, manner of dress, shoes, accessories and so on.

In French semiology, in the works of M. Foucault ${ }^{6}$, F. de Saussure, the subject (active creator, cultural change figure) is considered as a subject of discourse, and discourses are understood as suggestive, emotionally intense, energetic, socially defined acts speeches. Speech, unlike language, is related to articulation, with the act of informing. Speech, articulation of information becomes the discourse that acquires ontological status. At the activity level, the discourse is fixed at the subject level as a living producer, designer, actor, on stage, on the podium, and the subject of discourse that is formed in the image, in verbal information.

We noted above that fashion, as a set of complex processes and phenomena, exists as an activity of the subject, generating certain "means" aimed at achieving "result." In turn, the category of "means" is extremely synthetic, because a person can be both a subject and an object, and any thing, any item of clothing can become a "means". The category "result" of the activity related to the object of the activity. Unlike the object of activity, the subject is included in the discourse, in speech, in activity, in action, becomes what is presented and subsequently becomes a commodity. The peculiarity of this approach in the understanding of discourse is that everything becomes a commodity, everything becomes a medium of exchange, and activity supersedes those higher values that cannot be transformed into a commodity.

Ferdinand de Saussure introduces an understanding of the vision of the sign unit, which exists as the unity of the signified and the signifier, where the main is speech, and language is the mechanism, the automatic means of composing and forming speech and meanings. Saussure also points to dialecticisms, all the features of the speech, but important in his study is the definition of subjectivity of the sign as the unity of the signified and significant. Signified is conceptual in meaning and identification is sensual. That is, the sign remains a phenomenon of consciousness ${ }^{7}$. M. Foucault, in turn, speaks of the loss of the denatate (signified) or the loss of reference

${ }^{6}$ Fuko, M. (1996). Volya k istine: po tu storonu znaniya, vlasti i seksual'nosti. Raboty raznykh let. Moscow: Kastal'.

${ }^{7}$ Sossyur, F. de. (2004). Kurs obshchey lingvistiki (perevod s francuzskogo A. M. Sukhotina, pod redakciej i s primechanijami R.I. Shor). Moscow: Editorial URSS. (Lingvisticheskoe nasledie XX veka). 
(the relation between signifying and signifying) ${ }^{8}$. It happens that the denotation is no longer needed and only constitutional systems begin to exist, or what Jean Baudrillard defined as a simulacrum ${ }^{9}$.

Works that raise issues of discourse and discursive mechanisms in cultural practices focus on identifying the verbal discourse of fashion. First of all, it is R. Bart's work "The System of Fashion" $"$. He identified several discourses, firstly, the subject in fashion, that is, the thing as it was created, the second discourse - the image (photo in the magazine) and the third discourse - verbal, as the spoken language articulates in space. Particularly important for our study is such a vision of discourse, which determines the subject aspect is denotative, visual is symbolically figurative, verbal is one that has its own speech and discourse. Not only is it a natural language, it's also an image language. Bart pays particular attention to verbal discourse, a language limited to verbal analysis. Bart pays particular attention to verbal discourse, a language limited to verbal analysis. Thus, he defines a vistmentary code of clothing on the example of fashion photography, analyzing fashion magazines, identifies three features of fashion discourse: subject, pictorial, verbal.

In our view, R. Barthes defines the categories of discourse most ontologically universal in the work of "Mythology" , noting the myth, as a system in which there is a primary and secondary language. Therefore, the discourse of modern myths emerges in the mass culture as a discourse of advertising, fashion, and brand. This approach eliminates the category of sign, eliminates the sign itself and changes the category of discourse. Using the principles of Bart, the modern Russian researcher F. Kositskaya, considers fashion advertising discourse as polyphony of discourses on the example of fashion clothing catalogs ${ }^{12}$. D. Bashkatov defines the peculiarities of functioning of the Russian discourse of fashion, which has semantic codes that correlate with religious, military, musical, medical and other discourses ${ }^{13}$. Understanding fashion discourse as a polysystemic integrity is represented by a spectrum of subjects, according to Yu. Lehenky, where the subject of fashion discourse is a polyphonic manifestation. The subject of fashion is

${ }^{8}$ Fuko, M. (1996). Volya k istine: po tu storonu znaniya, vlasti i seksual'nosti. Raboty raznykh let. Moscow: Kastal'.

${ }^{9}$ Derrida, Zh. (2000). O grammatologii / perevod s francuzskogo i vstupitel'naja stat'ja N. Avtonomovoy. Moscow: Ad Marginem.

${ }^{10}$ Bart, R. (2003). Sistema Mody. Stat'i po semiotike kul'tury. Moscow: Izdatel'stvo im. Sabashnikovykh.

${ }^{11}$ Bart, R. (1996). Mifologii. Moscow: Moscow: Izdatel'stvo im. Sabashnikovykh.

${ }^{12}$ Kositskaya, F.L. (2006). Katalog mody kak simfoniya diskursov. Vestnik TGPU, 9. URL: http://cyberleninka.ru/article/n/katalog-mody-kak-simfoniya-diskursov.

13 Bashkatova, D.A. (2010). Sovremennyy russkiy diskurs mody. PhD Thesis. Moscow: Moskovskiy gosudarstvennyy universitet imeni M. V. Lomonosova. 
always a collective "figure", representing a particular community of preferences, interests, images, images, etc. ${ }^{14}$ "Only in the instances of discourse does language have a reference," notes P. Reeker, "to speak means to speak of something ${ }^{15}$ ". This is a very important statement for our study, because it refers to the meanings, to the realities of reality, in our case - a reference to the most archaic integrity. It is important to see the subject of fashion discourse as generic integrity, as an anthropological holistic image of a person, which generates the unity of the viewer and the one exhibiting the collection. In fashion, the identity of the information person and the viewer is identified. Such reference is made by means of discursive practices. The subject of discourse is embedded in the act itself, in the very temperament of fashion. So, in the article by Lola G.M. "Fashion discourse: from narrative cocoon to message" fashion discourse is defined as a socially engaged conversation about fashion. According to the author, fashion discourse is presented as a socially dictated dictatorship that depends on the speaker, whether it is a journalist, art critic, economist, historian, who defines the image of thoughts, values and actions. "The fact that fashion discourse is becoming more and more own is perceived as the norm, especially since the desire for total dictation is present in almost all social discourses of the postmodern" ${ }^{\text {. }}$. So Lola sees the understanding of discourse as a concept of social semiotics, "where discourse is first, a means of creating a version of reality, and second, a dynamic form of social practice, and third, a contextualization tool ${ }^{17}$.

O. Shandrenko's work "The virtual world of fashion" identifies the temporal acts of twentieth-century fashion that take place in the context of virtual reality and is defined as discursive practices, as a certain sealing, individualization, archaization and pluralization. The author notes how discursive practices become a polyphonic structural whole, which can be described as destruction, decomposition, reconstruction, in which the creative component, that is, the moment of creativity (from the latio creatio creation), as the transition from nothingness to being, takes proper place. Creativity plays a huge role; it is one of the discursive mechanisms. Discursive practices in fashion are manifested through the act of articulation, which is also seen as a certain formulation in costume. For example, if you

${ }^{14}$ Legen'kiy, Yu. (1998). Filosofiya mody XX stoletiya. Kyiv: KNUKIM.

15 Riker, P. (1995). Konflikt interpretatsiy: ocherki o germenevtike. Moscow: Medium, pp. 129-130.

${ }^{16}$ Lola, G.N. (2008). Diskurs mody: ot narrativnogo kokona k reklamnomu poslaniyu. In Moda $v$ kontekste kul'tury: sbornik statej Tret'ej naukovo-prakticheskoj konferencii, 3. St. Petersburg: SPbGUKI (pp. 83-88).

${ }^{17}$ Ibid., p. 84. 
consider the creativity of Italian designer Gianni Versace ${ }^{18}$ (1946-1997), and analyze the 1994 women's clothing collection in which he offered deep vertical cuts on a dress and try to decode such a construct as a designer message that came as a speech. On the one hand, it is a cardinal gesture, the willpower of masculine direction in the suit formation, because this is how the eye "cuts" a man's dress in order to see the hidden female body, and on the other, it is the substitution of male willpower when a man is given his wishes in vain in the imaginary, figurative world of fashion. A wish comes true without realizing it. Discourse here comes as an articulation of desire, as the total identity of the male desire and the couturier.

The masculinist civilization of the XX-XXI century is looking for its image. Trousers worn by women are considered to be brutal in the early twentieth century. And then, the pants are put on by a female jockey - and there is a certain palliative, which is at once perceived as a mask of masculinist civilization, which constitutes a certain discourse-play that seems to be misleading, but is essentially the broadcasting of a man's deep body code on a woman's body. There is an introversion of the formative guidelines in the form of a double game, as a dual modeling system.

In determining the discursive mechanisms in fashion, we identify issues that concern not only the physical characteristics of fashion items, but also try to understand the deep essence of her being. For example, a black dress (a small black dress by Coco Chanel (1926)), it is a garment of black color, made of a certain material for women's wear, has a certain shape and became widespread in the early twentieth century women all over the world ${ }^{19}$. This dress, in our opinion, gives rise to an image that refers to deep intuitions, to the Catholic faith, to monasticism. From biographical sources, we learn that Chanel lived with her novices in the monastery for a long time as a child. The Puritan ethos that surrounded her became, in the future, an unobtrusive mask of simplicity, of feminine virtue, manifested in a sacred religious image. Here we assume that there is an act, a discursive mechanism, where there is no play, substitution, mask, and there is a sacralization of the profane, which occurs as a virtual (in the sense - precious, possible), gestural projection in the reality of fashion as an image.

The masculinization that took place as a deep, cultural impulse, sounded by Coco Chanel as "a mask, a game of sports and non sports", was presented by Yves Saint-Laurent as a unique ${ }^{20}$. Uniformity of uniform is associated with military uniform, as with a unique code. Subsequently, gender unity became

\footnotetext{
${ }^{18}$ Zeling, Sh. (2000). Moda. Vek model'erov. 1900-1999. Moscow: Konemann.

${ }^{19}$ Ibid.

${ }^{20}$ Ibid.
} 
an extremely attractive youth impulse, for fashion 60-70 years and manifested itself in fashion trends, such as hippies, punks. Summarizing the above, it should be noted that the discursive practices inherent in high fashion masters are extremely sensitive mediums that perceive the intents and urges of culture and translate them into the level of fashion code, into the level of fashionable clothing. So, for example, the image of unisex is not only the image of androgyny; the unity of male and female and it is not only a natural unity, not a game of male and female in the form of transversions that occurred in carnival variations, in the fashion of couture, but it is a certain norm, difference gender between a man and a woman that happens as a challenge of time, an act that becomes a kind of escape from complex problems.

\section{Livestock fashion}

The purpose of this article is to reveal the gesture of fashion as a certain figurative guideline, which has its articulation of meanings, signs. There are two explanations of the word "gesture" in the Ukrainian dictionary. Therefore, it can mean the movement of the body or hands that accompanies or replaces human language and the act or behavior of a person caused by certain intentions ${ }^{21}$. Dahl Dictionary provides such an interpretation of the word "gesture", which comes from the French (geste), is movement of the human body, silent language is forced or free, endowed with signs, movement of thoughts and feelings ${ }^{22}$. Thus, we may regard the gesture as, in the first case is message, meaningful information, and in the other is as sign-completed message, where the sign carries certain information.

Mr Darwin, while exploring the nervous system of humans and animals, observed the influence of emotions on the body that occurs regardless of desire. A nervous system that is so excited can cause a direct intervention in the expression of will. The scientist believed that any movement of the human body is necessarily accompanied by a mind state, which immediately sees in them authentic, expressive movements ${ }^{23}$. However, in the context of our problem, we are not talking about feelings, but about their outward manifestation, as a sign of that feeling. According to S. Volkonsky, each signbehavior is an imitation of the manifestation of one's own body; a sign-word is a sign concept ${ }^{24}$. There is Brodetsky in the work "Silent communication in life and art. $\mathrm{ABC}$ of Silence" provides a systematic formation of the sign

${ }^{21}$ Slovnyk ukrajinsjkoji movy: v 11 tomakh. (1971). Tom 2. URL: http://sum.in.ua/p/2/522/2.

${ }^{22}$ Dal', V.I. (2013). Tolkovyy slovar' zhivogo velikorusskogo yazyka: v 4 t. URL: http://mirslovarei.com/content_dal/zhest-8073.html.

${ }^{23}$ Darvin, Ch. (2001). O vyrazhenii emotsiyu cheloveka i zhivotnykh. St. Petersburg: Piter. (Seriya "Psikhologiya-klassika").

${ }^{24}$ Volkonskiy, S.M. (1913). Vyrazitel'nyy chelovek. St. Petersburg: SIRIUS. 
system and determines that non-verbal visual communication is the basic form of the two signs "I" and a single sign "We", taking into account the value of each individual. Thus, a non-verbal sign, the gesture becomes meaningful every time it is used ${ }^{25}$. In the work "Body Language: Nature and Culture", devoted to the evolutionary and cross-cultural foundations of non-verbal human communication, M.L. Butovskaya notes that body language is the result of close interaction between biology and culture ${ }^{26}$.

In a broader sense, N. Mankovskaya argues that in the culture of the late twentieth century and at the beginning of XXI century there is a "depletion of language", there is an intensified interest in the physical, not verbal, but visual, plastic, gestural, and that is why there is an exacerbation of the question between the real, everyday, surreal, hallucinatory, psychedelic, mystical $^{27}$. Body language creates a physical sphere of cruelty, according to A. Artaud ${ }^{28}$, embodying the creator's will, metaphysics in the soul through the skin, as will, cry, gesture, hieroglyph sign. Thus manages to break through to the other side of the language, N. Mankovskaya believes, to carry out the socalled exorcist rite of spiritual purification to the primary, cosmic. Therefore, sign language sometimes becomes a hint, a metaphor, a sign, a puzzle, or an answer.

P. Bogatyrev in "Signs in theatrical art" defines the importance of actor gestures for theater viewers, noting that the characters expressed by the actor have a dual perception. First, thanks to gestures, signs become vital, and secondly, they remind us that one cannot identify an actor with his face, suit, gestures, because these are only signs depicting action ${ }^{29}$. Therefore, those non-verbal communications that the actor performs in the theater only play a role. The particularity of attention due to the movements of the sleeves of clothing used in Chinese culture, draws attention G. Kreydlin in the work of Y. Sorokin and A. Morkovina, who study the types of symbolism in the language and culture of $\mathrm{China}^{30}$.

Tatiana Grigoryants in cultural and historical analysis of the calisthenics arts captures phenomenon close bodily manifestations, which are information

25 Brodetskiy, A.Ya. (1999). Vnerechevoe obshchenie v zhizni i v iskusstve. Azbuka molchaniya. Moscow: Vysshaya shkola, pp. 213-216.

${ }^{26}$ Butovskaya, M.L. (2004). Yazyk tela: priroda i kul'tura. Moscow: Nauchnyy mir, pp. 12-13.

27 Man'kovskaya N.B. (2005). Khronotipologicheskie etapy razvitiya neklassicheskogo esteticheskogo soznaniya. Estetika: Vchera. Segodnya. Vsegda, 1. Moscow: IF RAN. URL: http://iph.ras.ru/page52503979.htm.

${ }^{28}$ Arto, A. (2000). Teatr i ego Dvoynik. St. Petersburg: Simpozium.

${ }^{29}$ Bogatyrev, P.G. (1975). Znaki v teatral'nom iskusstve. In Trudy po znakovym sistemam, 7. Tartu: TGU (pp. 7-36).

${ }^{30}$ Sorokin, Yu.A. \& Markovina, I.Yu. (1988). Tipy kitayskoy simvoliki v yazyke i kul'ture. In Etnopsikholingvistika (red. Yu. A. Sorokin). Moscow: Nauka (pp. 64-71). 
that complements the era picture, gives an idea of its specificity, about the person, about the state of his spiritual world. The physicality phenomenon stands in the unity of two aspects: they are the inner world of the actor and the outside world is the viewer's perception. An interrelation is determined by belonging to cultural specimens and processes of a specific historical era ${ }^{31}$.

P. Florensky problematized the idea of body and clothing, arguing for a deep connection of the unity vision, where clothing becomes a loud means of expressing the body idea ${ }^{32}$. That is, if the body recognizes the ability to reproduce specifically the metaphysics of the human being, then clothing becomes an auxiliary means of understanding the "essence of enlightened humanity". Clothes always have places, belts of contact with the body. We notice when there is a certain nod and women's accessories begin to move in tact with the head, reinforcing such a gesture. When in ancient Rome the emperor made a demonstration gesture with his left hand, and then a toga, reinforcing the decision, accompanied his will. Gesture acts as a communicative norm of behavior, as a framework limited by the space of culture.

An important characteristic of gesture is the demonstration, the message of unity between the body and the culture, meanwhile, "you", on whom "I" depends. Such a question of gesture is directed to the outside, to the space of culture, as a certain union between "I" and "you". "For the fashion designer, the most important is the body," says Yu. Lehenky, "his gesture as a kind of

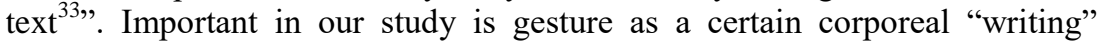
of fashion. Gesture as a dissolved space of the body, turned both in the middle of the body and outwards. There is extraversion and introversion of bodily articulation of the fashion, bodily transgression. Therefore, extraversion occurs as articulation aimed at the unity of culture and man, as its socialization. In fashion, this is manifested as a desire for sociality and acceptance that dictates certain behaviors and norms.

Another mechanism of fashion articulation is the communicative technologies of image creation, fashion brands, which are created in the context of a particular genre of cultural creation, symbolizing and provoking a different reality ${ }^{34}$.

${ }^{31}$ Grigor'yants, T.A. (2004). Kul'turno-istoricheskiy analiz fenomen plasticheskikh iskusstv. $\mathrm{PhD}$ Thessis. Kemerovo, p. 11.

${ }^{32}$ Florenskiy, P. (1993). Ikonostas. Izbrannye trudy po iskusstvu. St. Petersburg: Russkaya kniga, p. 112.

${ }^{33}$ Legen'kiy, Yu. \& Tkachenko, L. (1998). Sistema modi: kul'turologiya, estetika, dizayn. Kyiv: GALPU, p. 113.

${ }^{34}$ Shandrenko, O. (2011). Virtualjnyj prostir mody. Kyiv: KNUKIM. 
S. Volkonsky wrote that each person is the center of the imaginary circle, where it is the starting point of its own manifestations and the final point of its own perception, and there is still a center in itself as a calm equilibrium ${ }^{35}$. The manifestation of physical or spiritual activity occurs only in these directions, so another articulation mechanism of fashion's gesture is introversion, as immersion in one's own world of imagination and thought. The very manifestation of bodily "writing" through one's own visions and perceptions of the world testify to the bodily transgressions that take place in the twentieth-century fashion. Since the First World War, when women had to work and perform hard work on a level with men, when feminist movements emerged (for example, Georges Sand, a 19th-century French writer who wore trousers), when Oriental culture (collections) was actively popularized. "The Thousand Second Night, or Celebration in Persian", 1911) is as a manifestation of equality and comfort began to enter the elements of men's wardrobe. In 1930, famous film an actress Marlene Dietrich starred in the film "Morocco", directed by Joseph von Sternberg, in menswear. In those same years, Coco Chanel became the first designer to design and offer women's trousers for outdoor walks, recreation and sports ${ }^{36}$. Therefore, the appearance in the European women's wardrobe of the analogue of men's trousers came as a symbol of the embodiment of experiences of mass instinct, as a bodily experience of internal reaction.

Designer, master, couturier transmits her own experiences through callisthenics, artwork and shaping. This manifestation of the inner world of Coco Chanel became her legendary black dress (1926), the most famous model of the twentieth century ${ }^{37}$. You can try to identify the articulatory mechanism as a reproduction of the inner, subconscious, which prompted her to act and create, and then we will see the tragic fate of a little girl brought up in a shelter at the monastery. Inside experiences, visions of contrasting black and white, both in clothing and in life, as clear, nun-shaped outfits, go through all of Chanel's creative work and become a sensual manifestation of the small-body gesture. Such a gesture of expression of the French woman was able to combine the aristocratic and democratic preferences of women in all European fashion and marked the further path of fashion development.

Particularly noteworthy is the work of Christian Dior, his alphabetical and conceptual concept of creating silhouettes of clothing, fascinating and impressive. Dior was trying to create some symbolic fashion language that could reproduce the inner alphabet of form and image. His work is aimed at singing the female body, was accepted by the majority of admirers, because all

\footnotetext{
${ }^{35}$ Volkonskiy, S.M. (1913). Vyrazitel'nyy chelovek. St. Petersburg: SIRIUS.

${ }^{36}$ Moda i stil'. (2002). Sovremennaya entsiklopediya. Moscow: Avanta.

${ }^{37}$ Ermilova, D. (2003). Istoriya domov mody. Moscow: ACADEMA.
} 
around were tired and exhausted by wars, poverty and sorrow ${ }^{38}$. The desire to create a non-verbal system of signs, which was indicated in the silhouette forms of the clothing collection, led to the appearance in 1954 of the clothing line, denoted by the name " $H$ ", where the line of the shoulders and hips were on the same level, in 1955 was the clothing line "Y" determined by the silhouette of the triangle, and even after the death of the couturier, line "A" with a uniform extension of the silhouette, where the horizontal served as a low waist line ${ }^{39}$.

If we considered the previous consideration of the genius of the fashion phenomenon as belonging and unity, then it is also worth stopping at the gesture as a protest, as an inner will and rejection, an alienation that can occur at the psychological, cultural and social levels. Such expression can be attributed to the subcultural trends and artistic practices of the XX-XXI centuries. Internal struggle, anxiety, not acceptance of the world is due to the rejection of established aesthetic notions of beauty and harmony, norms of behavior, the desire to escape from reality, etc. Such internal destructive processes lead to the search for new ideals, images, idols, meanings of life and solutions to various cultural issues. In addition to alienation from the world, in such subcultures there is a desire to unite, spread and disseminate its ideology, and attract new adherents to its ranks. They create their own fashion, image, special articulatory mechanisms, rituals that are understood only by circles belonging to this subculture. In this case, there is a double gesture directed as outward, into culture - appearance shouts, protests, tells everyone about ideological attitude, engaging in communication, and gesture directed in the middle, as will of internal state, sadness, unwillingness, protest, search. Thus, the gesture of the fashion trend in the subcultural space provides a person' special state, simulates one or another manner of its behavior, generates new images, signs and changes in culture.

\section{CONCLUSIONS}

Discursive practices of fashion are a reflection of intention (as conscious or subconscious intent), designer, culture, age, time. The system of discursive mechanisms becomes the most common means of displaying information in fashion. And discursive practices are understood as communicative speech on the ontological, community level, as a certain act. There are discursive mechanisms of fashion that can describe the integrity of fashion: gesture, plasticity, indifference, temporality, etc. The polyphonic vision of the category discourse leads to further research, where fashion should be considered as a possible linguistic articulation in its stylistic definition, when

${ }^{38}$ Shandrenko, O.M. (2013). Zhestualjnistj mody v konteksti neverbaljnoji komunikaciji. Aktualjni problemy istoriji, teoriji ta praktyky khudozhnjoji kuljtury, 30, 246-253.

${ }^{39}$ Moda i stil'. (2002). Sovremennaya entsiklopediya. Moscow: Avanta. 
every designer, designer works in the context of pictorial, plastic, architectonic, signifying practices of fashion. The discourse paraphrases the subject realities of culture into a dynamic series of presentation of information that unfolds as a certain reading of information in time, in the space of culture.

Gesture is a very important articulatory, discursive mechanism, characteristic of fashion in general, but it acquires special features in the last decades of the twentieth century. The problem of the will of the body, gesture as non-verbal communication in fashion creates new images, silhouettes, new shaping guidelines, which in turn are dictated and disseminated by the means of communication technologies. The gesture got rid of clichéd archaic features, as it did in the early archaic cultures, and inherited the sculptural plastic, cosmological experience of culture. This gesture is fixed in the eidos, in the image, in the virtual world; it becomes a plastic world that is transformed by various computer technologies, which enters into the cycle of human space as a simulacrum, as a brand, as the integrity of the information presented on the screen in various artistic and pictorial practices.

\section{SUMMARY}

The article deals with the study of fashion as a complex, multifaceted phenomenon of culture, the need for a complex, multidisciplinary approach, to determine the communicative function of fashion in the space of culture. The author notes that fashion, as a cultural, social phenomenon, has its own discursive practices, which act as a kind of thesaurus. This interpretation of fashion discourse is similar to certain mechanisms used in visual practices. Visual practice becomes one of those discursive mechanisms that provide the fashion for its existence. Visuality manifests itself as an image, as the presence of a fashion world without which fashion cannot take place. The realization of fashion exists at the expense of the dominant visual-visual series, that is, the identification of images and meanings, in the discourse of fashion, which are predominantly iconic, gestural rather than verbal. Fashion gesture has its own articulatory mechanism, which in the horizon of modern culture is an important tool that is only looking for its alphabet, the rules of articulation, its grammar.

\section{REFERENCES}

1. Arto, A. (2000). Teatr i ego Dvoynik. St. Petersburg: Simpozium.

2. Bart, R. (1996). Mifologii. Moscow: Moscow: Izdatel'stvo im. Sabashnikovykh.

3. Bart, R. (2003). Sistema Mody. Stat'i po semiotike kul'tury. Moscow: Izdatel'stvo im. Sabashnikovykh.

4. Bashkatova, D.A. (2010). Sovremennyy russkiy diskurs mody. $\mathrm{PhD}$ Thesis. Moscow: Moskovskiy gosudarstvennyy universitet imeni M.V. Lomonosova. 
5. Bodriyyar, Zh. (2013). Simulyakry i simulyatsiya. Tula: Tul'skiy poligrafist.

6. Bogatyrev, P.G. (1975). Znaki v teatral'nom iskusstve. In Trudy po znakovym sistemam, 7. Tartu: TGU (pp. 7-36).

7. Brodetskiy, A.Ya. (1999). Vnerechevoe obshchenie v zhizni i v iskusstve. Azbuka molchaniya. Moscow: Vysshaya shkola.

8. Butovskaya, M.L. (2004). Yazyk tela: priroda i kul'tura. Moscow: Nauchnyy mir.

9. Dal', V.I. (2013). Tolkovyy slovar' zhivogo velikorusskogo yazyka: v 4 t. URL: http://mirslovarei.com/content_dal/zhest-8073.html.

10. Darvin, Ch. (2001). O vyrazhenii emotsiyu cheloveka i zhivotnykh. St. Petersburg: Piter. (Seriya "Psikhologiya-klassika").

11. Derrida, Zh. (2000). O grammatologii / perevod s francuzskogo i vstupitel'naja stat'ja N. Avtonomovoy. Moscow: Ad Marginem.

12. Ermilova, D. (2003). Istoriya domov mody. Moscow: ACADEMA.

13. Florenskiy, P. (1993). Ikonostas. Izbrannye trudy po iskusstvu. St. Petersburg: Russkaya kniga.

14. Fuko, M. (1996). Arkheologiya znaniya. Kyiv: Nika-Tsentr.

15. Fuko, M. (1996). Volya k istine: po tu storonu znaniya, vlasti i seksual'nosti. Raboty raznykh let. Moscow: Kastal'.

16. Grigor'yants, T.A. (2004). Kul'turno-istoricheskiy analiz fenomen plasticheskikh iskusstv. $\mathrm{PhD}$ Thessis. Kemerovo.

17. Khiz, Dzh. \& Potter, E. (2007). Bunt na prodazhu. Moscow: Izdatel'stvo "Dobraya kniga".

18. Kositskaya, F.L. (2006). Katalog mody kak simfoniya diskursov. Vestnik TGPU, 9. URL: http://cyberleninka.ru/article/n/katalog-mody-kaksimfoniya-diskursov.

19. Kreydlin, G.E. (2008). Neverbal'naya kommunikatsiya $\mathrm{v}$ teatre $\mathrm{i}$ zhivopisi. Alatoo Academic Studies, 3, 1, 40-50.

20. Kreydlin, G.E. (2002). Neverbal'naya semiotika. Yazyk tela i estestvennyy yazyk. Moscow: Novoe lit. obozrenie.

21. Legen'kiy, Yu. (1998). Filosofiya mody XX stoletiya. Kyiv: KNUKIM.

22. Legen'kiy, Yu. \& Tkachenko, L. (1998). Sistema modi: kul'turologiya, estetika, dizayn. Kyiv: GALPU.

23. Leghenjkyj, Ju.Gh. (2008). Dyzajn odjaghu. Kyiv: KNUKiM.

24. Lola, G.N. (2008). Diskurs mody: ot narrativnogo kokona k reklamnomu poslaniyu. In Moda v kontekste kul'tury: sbornik statej Tret'ej naukovo-prakticheskoj konferencii, 3. St. Petersburg: SPbGUKI (pp. 83-88).

25. Lotman, Yu.M. (1992). Izbrannye stat'i: v 3-kh tomakh. T. I: Stat'i po semiotike i topologii kul'tury. Tallin: Aleksandra.

26. Lurie, A. (1981). The Language of Clothes. London: Bloomsbury. 
27. Lyusher, M. (1996). Signaly lichnosti. Khar'kov: AO Sfera.

28. Man'kovskaya N.B. (2005). Khronotipologicheskie etapy razvitiya neklassicheskogo esteticheskogo soznaniya. Estetika: Vchera. Segodnya. Vsegda, 1. Moscow: IF RAN. URL: http://iph.ras.ru/page52503979.htm.

29. Moda i stil'. (2002). Sovremennaya entsiklopediya. Moscow: Avanta.

30. Riker, P. (1995). Konflikt interpretatsiy: ocherki o germenevtike. Moscow: Medium.

31. Rusakova, O.F. \& Rusakov, V.M. (2008). PR-Diskurs: Teoretikometodologicheskiy analiz. Ekaterinburg: UrO RAN, Institut mezhdunarodnykh svyazey.

32. Shandrenko, O. (2011). Virtualjnyj prostir mody. Kyiv: KNUKIM.

33. Shandrenko, O.M. (2013). Zhestualjnistj mody v konteksti neverbaljnoji komunikaciji. Aktualjni problemy istoriji, teoriji ta praktyky khudozhnjoji kuljtury, 30, 246-253.

34. Shandrenko, O. (2015). Interpretacija mody v konteksti dyskursyvnykh praktyk. Almanac "Culture and Contemporaneity", 2, 132-137. DOI: http://dx.doi.org/10.32461/2226-0285.2.2014.147248.

35. Slovnyk ukrajinsjkoji movy: v 11 tomakh. (1971). Tom 2. URL: http://sum.in.ua/p/2/522/2.

36. Sorokin, Yu.A. \& Markovina, I.Yu. (1988). Tipy kitayskoy simvoliki v yazyke i kul'ture. In Etnopsikholingvistika (red. Yu. A. Sorokin). Moscow: Nauka (pp. 64-71).

37. Sossyur, F. de. (2004). Kurs obshchey lingvistiki (perevod s francuzskogo A. M. Sukhotina, pod redakciej i s primechanijami R.I. Shor). Moscow: Editorial URSS. (Lingvisticheskoe nasledie XX veka).

38. Volkonskiy, S.M. (1913). Vyrazitel'nyy chelovek. St. Petersburg: SIRIUS.

39.Zeling, Sh. (2000). Moda. Vek model'erov. 1900-1999. Moscow: Konemann.

\section{Information about the author: Olha Shandrenko,}

Candidate of Arts, Associate Professor, he Senior Lecturer of the Design and Technologies Department, Kyiv National University of Culture and Arts, 36, Y. Konovalets str., Kyiv, 01133, Ukraine http://orcid.org/0000-0001-5284-7252 
NOTES 
NOTES 
Publishing house "Liha-Pres"

9 Kastelivka str., Lviv, 79012, Ukraine 44 Lubicka str., Torun, 87-100, Poland

Printed by the publishing house "Liha-Pres"

Passed for printing: January 27, 2020.

A run of 150 copies. 